\title{
Continuity or Change? (In)direct Rule in British and French Colonial Africa
}

\author{
Carl Müller-Crepon* \\ ETH Zurich
}

May 2020

Accepted at International Organization

\begin{abstract}
Current political order in Africa is often linked to legacies of colonialism, in particular to legacies of indirect colonial rule. However, evidence about the application of indirect rule is scarce. In this paper I argue that empire-level characteristics interacted with precolonial institutions in shaping the indirectness of local rule. First, British governments ruled more indirectly than French administrations, which followed a comparatively centralized administrative blueprint, came with a transformative republican ideology, and had more administrative resources. Empirically, I find that French colonization led to the demise of the lines of succession of seven out of ten precolonial polities, twice as many as under British rule. Second, precolonial centralization was a crucial prerequisite for indirect rule. Local administrative data from eight British colonies show that British colonizers employed less administrative effort and devolved more power to native authorities where centralized institutions existed. Such a pattern did not exist in French colonies. Together, these findings improve our understanding of the long-term effects of precolonial institutions and draw attention to the interaction of characteristics of dominant and subordinate units in shaping local governance arrangements.
\end{abstract}

\footnotetext{
*email: carl.mueller-crepon@icr.gess.ethz.ch. I thank the editor Erik Voeten, two anonymous reviewers, Robert Bates, Lars-Erik Cederman, Lauren Honig, Simon Hug, Philipp Hunziker, Horacio Larreguy, Emmy Lindstam, Yannick Pengl, Thomas Sattler, as well as participants in seminars at Harvard University and ETH Zurich, the APSA Annual Meeting 2018, and the SPSA Conference 2018 for helpful discussions, comments, and suggestions.
} 


\section{Introduction}

As in most instances of imperial conquest, the question of how to rule indigenous populations and how to treat their elites was a paramount preoccupation of European colonial officials in Africa. Debates about the benefits and disadvantages of direct and indirect rule dominated much of the general discussion on colonialism after the "Scramble for Africa" in the late nineteenth century. This did not change much after the establishment of colonial rule, and the topic marks scholarly debates and research to this day. It is thus remarkable that we lack systematic data and evidence on where and to what extent indirect colonial rule was actually applied.

I confront this issue head-on and study the indirectness of local British and French rule in nonsettler colonies in Africa. I first test the argument that the French empire was comparatively hostile toward precolonial polities while the British often chose a path of cooptation. Data on the (dis-)continuation of the lines of succession of precolonial polities in the two empires support this argument. Second, I test the claim that indirect rule worked best where it could build on centralized precolonial institutions. Data on local administrations in British colonies conform to this hypothesis.

Strategies of direct and indirect rule shaped the nature of colonial conquest and governance in Africa. Arguments about the application of direct and indirect rule in colonial Africa roughly follow two lines. The first is concerned with differences between, in particular the French and British, empires. Some argue that both relied on local intermediaries to the same extent. ${ }^{1}$ Others, however, claim to see marked differences in their treatment of pre-existing institutions and provide evidence that

\footnotetext{
${ }^{1}$ Gerring et al. 2011; Herbst 2000; Mamdani 1996.
} 
French rule was more direct than its British counterpart. ${ }^{2}$ This difference is related to the centralized French administrative blueprint and republican ideology, as well as the stronger resource constraints of British colonial government. A second literature has explored within-colony variation of indirect rule and stresses the role of precolonial institutions. These were either sufficiently centralized or too fragmented for integration into schemes of indirect rule. ${ }^{3}$ Despite focusing on one of the most important features of colonial domination, the debate on indirect rule so far lacks comprehensive evidence on variation in its application within and between French and British colonies.

Far from being an issue specific to the European colonies in Africa, the question of direct versus indirect rule defines the hierarchical relation between political entities and points to contrasting ways of creating political order in empires, states, and areas under military occupation. ${ }^{4}$ Across world history, "composite states" 5 such as China, Rome, the European contiguous and overseas empires, as well as the Soviet Union featured diverse power arrangements between their core and subordinate units. $^{6}$ Moreover, similar variation in vertical relations between dominant and subordinate entities structures intrastate and interstate hierarchies. ${ }^{7}$ Focusing on how colonial domination was translated into empirically observable power relations within British and French colonies in Africa, my study lies at the intersection between the intra- and interstate realm. My results draw attention to the crucial interaction between characteristics of the dominant and subordinate entities

\footnotetext{
${ }^{2}$ Asiwaju 1970; Crowder 1968; Miles 1994.

${ }^{3}$ Fortes and Evans-Pritchard 1940; Gerring et al. 2011.

${ }^{4}$ Cooley 2005; Hobson and Sharman 2005.

${ }^{5}$ Nexon 2009.

${ }^{6}$ For example, Burbank and Cooper 2010; Gerring et al. 2011.

${ }^{7}$ Lake 2009. On the concept of hierarchy in the IR literature, see Mattern and Zarakol 2016.
} 
in structuring political hierarchy.

Explaining the determinants of indirect colonial rule also sheds light on the origins of current political order and socioeconomic development in Africa. Because indirect rule has a strong ethnic basis, it has been linked to the historical (trans)formation of ethnic inequalities,${ }^{8}$ identities,${ }^{9}$ customary institutions, ${ }^{10}$ and land rights. ${ }^{11}$ Similarly, local variation in the character of colonial rule likely determines the effect of colonialism as a whole. ${ }^{12}$ Finally, indirect rule is considered one of the prime historical pathways through which precolonial factors persistently affect economic development. ${ }^{13}$

For the empirical analysis, I draw on a variety of systematic historical data sources. To examine differences in the indirectness of rule in the French and British empires, I analyze encyclopedic data on the lines of succession of 124 colonized polities in Africa. ${ }^{14}$ Taking the end of a polity's line of succession as a proxy for its demise, the data show that only 30 percent of the polities colonized by the French but 70 percent of those colonized by the British survived colonial rule. This large difference holds across plausibly exogenous French-British borders that run perpendicular to the West African coastline.

I then assess the effect of precolonial institutions on the indirectness of rule by analyzing newly collected data on local administrations in eight British colonies. These archival data from official reports shed light on the colonial and indigenous dimensions of local governance under direct and indirect rule. The colonial dimension

\footnotetext{
${ }^{8}$ Wucherpfennig, Hunziker and Cederman 2016.

${ }^{9}$ Ali et al. 2018; Ranger 1997.

${ }^{10}$ Baldwin 2016.

${ }^{11}$ Berry 1992; Boone 2003; Firmin-Sellers 2000.

${ }^{12}$ Bruhn and Gallego 2012; Iyer 2010; Lange 2009; Lankina and Getachew 2012; Mamdani 1996.

${ }^{13}$ For example, Gennaioli and Rainer 2007; Michalopoulos and Papaioannou 2013.

${ }^{14}$ Stewart 2006.
} 
concerns the administrative effort that the British exerted. Where they could rule indirectly through precolonially centralized institutions, the British exerted less effort as indicated by larger districts and fewer European administrators. In the same vein, chiefs in centralized areas presided over larger budgets and enjoyed higher status. These patterns are absent or even reversed in comparable data from French West Africa.

\section{Literature}

A crucial dimension of local governance arrangements in territories under alien dominance is the degree to which the imperial power cedes authority to the subordinate units it rules. ${ }^{15}$ While direct rule comes with high implementation costs for rulers, they can reap long-run benefits by circumventing independent intermediaries who can otherwise pocket parts of the state's revenues and block policy implementation. Conversely, indirect rule is cheap to implement but necessitates sharing revenues with subordinate actors. ${ }^{16}$ The search for effective local rule was thus no less a constant issue for rulers of "composite states" 17 in Europe and Asia ${ }^{18}$ than for the European imperialists in Africa. ${ }^{19}$ After the "Scramble for Africa," the new rulers had to devise ways to secure their hegemony over the conquered populations while being constrained by the few European officers available to administer their vast territories. ${ }^{20}$

\footnotetext{
${ }^{15}$ Gerring et al. 2011.

${ }^{16}$ Levi 1988.

${ }^{17}$ Nexon 2009.

${ }^{18}$ Burbank and Cooper 2010; Hechter 1975; Tilly 1975; Weber 1977.

${ }^{19}$ Hailey 1945; Lugard 1965.

${ }^{20}$ Kirk-Greene 1980.
} 


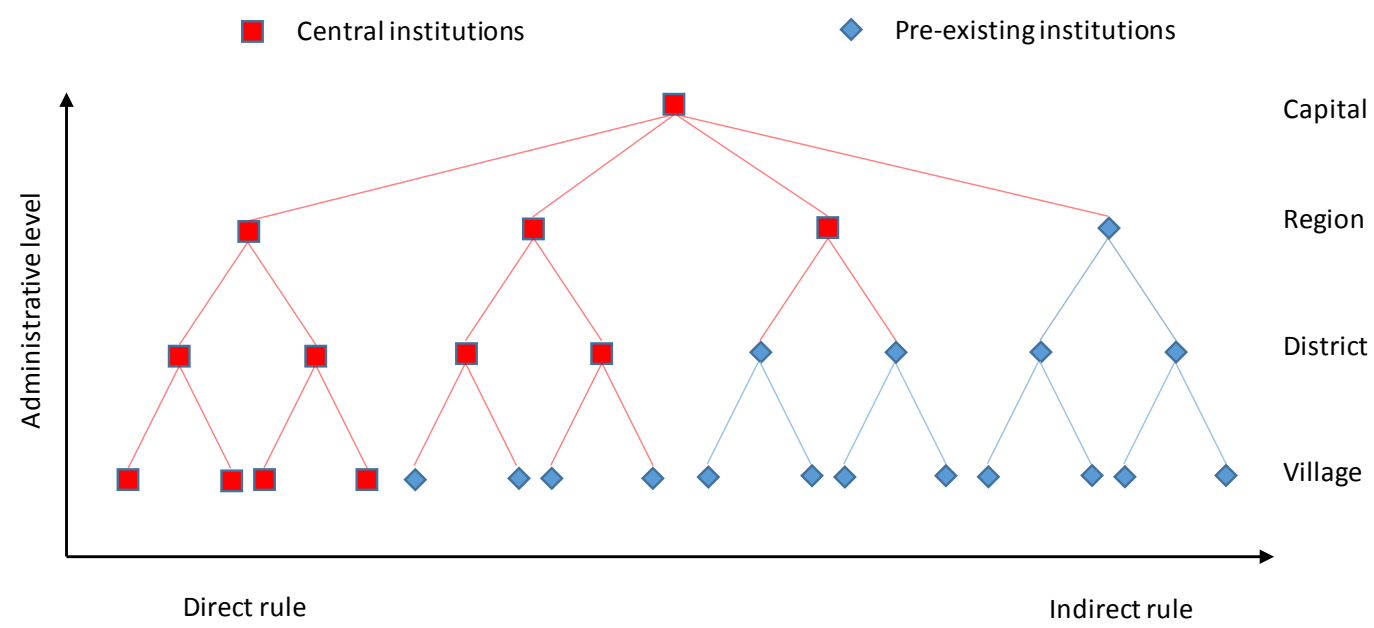

Figure 1: Conceptualization of indirect rule

All colonial powers relied to a significant degree on local intermediaries ${ }^{21}$ to bridge the social, organizational, and geographical distance between the colonial centers and local populations. Noting the precolonial basis on which these intermediaries were at times appointed, Herbst claims that colonial empires relied on the great variety of existing institutions to keep the costs of occupation at a minimum. For Herbst, "the Africans were unimpressed with the extent of the administrative reforms made by the white man." ${ }^{22}$ This perspective contrasts with descriptions of disrupted local governance, apparent in Young's "Crusher of Rocks" in the Belgian Congo, or Achebe's fictional depiction of British colonialism in Southeastern Nigeria where "things fell apart." 23

A focus on the nature of local institutions helps to reconcile the divergent views on the continuity and change in local governance arrangements. In the most general terms, we can distinguish between traditional, precolonial institutions integrated into

\footnotetext{
${ }^{21}$ Gerring et al. 2011.

${ }^{22}$ Herbst 2000, 84.

${ }^{23}$ Young 1994; Achebe 1958.
} 
the colonial state, and new institutions created by the colonial state (Figure 1). Full indirect rule defines a case in which the state integrates pre-existing institutions at all administrative levels below the central government. The more levels of hierarchy between the state center and its subjects consist of institutions created by the state itself, the more direct the mode of rule becomes. ${ }^{24}$ Full direct rule is a scheme of governance in which the colonial government creates all institutions that reach down to its subjects. With this perspective, we can distinguish intermediaries embedded in precolonial institutions from those that were not.

The literature on local colonial governance has explored two main axes of variation in the degree to which it integrated pre-existing institutions. The first concerns the colonizer's identity and discusses the difference between French and British styles of local rule. Deschamps, governor of the Côte d'Ivoire, famously claimed that "one can scarcely detect the French administrative policy previous to 1945; it differed from [Britain's] ... only in its more familiar style and less clearly defined goals." 25 Many have followed Deschamps's claim and argued that all colonial states ruled through local intermediaries and thus indirectly. ${ }^{26}$ However, others maintain that, although both empires relied on local intermediaries, the French approached local rule in a more direct fashion than the British. ${ }^{27}$ In this dichotomy, the British are described as co-opting pre-existing institutions where they existed. The French in turn were comparatively hostile toward them, often replacing them with their own institutions.

The second body of literature argues that traditional, precolonial institutions

\footnotetext{
${ }^{24}$ Gerring et al. 2011.

${ }^{25}$ Cited in Herbst, 2000, 82.

${ }^{26}$ For example, Gerring et al. 2011; Herbst 2000; Mamdani 1996.

${ }^{27}$ Asiwaju 1970; Crowder 1968; Hailey 1945; Miles 1994.
} 
could best be used as tools for indirect rule where they were sufficiently centralized to be integrated into the colonial administration. ${ }^{28}$ In acephalous, stateless societies, colonizers had to make up for the absence of readily available hierarchical political structures and establish institutions foreign to the local population. ${ }^{29}$

Despite the importance of these two debates for understanding the creation of political order in African colonies, no systematic and disaggregated evidence exists on where colonizers ruled indirectly. The most valuable within-empire measure uses the proportion of court cases handled by native courts as a proxy for differences in indirect rule between British colonies. ${ }^{30}$ Earlier, Herbst proxied the directness of colonial rule via the density of colonial road networks which might misleadingly relate to investments for economic development rather than direct rule. ${ }^{31}$ The best cross-empire proxy draws on the number of European administrators employed by the empires. In 1938, French colonial governance employed 250 administrators per million inhabitants in French West and Equatorial Africa. They compared to a mere twenty-nine administrators per million employed in 1939 in British colonies in Africa. ${ }^{32}$ Despite their value, these data do not capture within-colony as well as cross-empire variation in indirect rule. Such an endeavor requires subcolony information that spans colonial empires. ${ }^{33}$

In sum, existing evidence on indirect colonial rule is limited in two important ways. First, no systematic evidence on the difference between the indirectness of rule in French and British colonies exists. Second, no systematic and spatially dis-

\footnotetext{
${ }^{28}$ For example, Gerring et al. 2011; Hicks 1961; Tignor 1971.

${ }^{29}$ Fortes and Evans-Pritchard 1940.

${ }^{30}$ Lange 2009.

${ }^{31}$ Herbst 2000.

${ }^{32}$ Herbst 2000; Kirk-Greene 1980.

${ }^{33}$ For a focus on single colonies, see McNamee 2019 on Namibia, Nathan 2019 on Northern Ghana, and Iyer 2010 on India.
} 
aggregated evidence sheds light on the effect of precolonial institutions on indirect rule. This limits our understanding of how colonial rulers built their states in collaboration with or at the expense of their predecessors. After laying out the respective theoretical and historical arguments, I provide both types of evidence.

\section{Local Colonial Rule: French and British Style}

Institutions and methods, in order to command success and promote the happiness and welfare of the people, must be deep-rooted in their traditions and prejudices.

—Lord Lugard, governor-general of Nigeria ${ }^{34}$

Suppress the great native polities which are nearly always a barrier between us and our subject.

—William Ponty, governor-general of French West Africa. ${ }^{35}$

As these two quotes of French and British governor-generals in West Africa illustrate, the official stance toward indigenous authorities differed substantially between the two colonizing powers. In particular in the formative years of nonsettler colonies ${ }^{36}$ the French strove to establish a rather uniform system of direct rule, a system based on French, rather than pre-existing institutions. ${ }^{37}$ In comparison, the British approach to colonial rule followed the ideal of regional and local selfgovernment but was constrained where centralized institutions were absent. ${ }^{38}$ Sum-

\footnotetext{
${ }^{34}$ Lugard 1965, 211.

${ }^{35}$ Suret-Canale 1988, 150.

${ }^{36}$ Settler colonialism did not necessarily follow the logic presented below because it came automatically with more direct rule. However, causation might have run reversely: areas without strong and resisting precolonial institutions might have attracted more settlers. Huillery 2010.

${ }^{37}$ At least until the end of World War I. Conklin 1997 suggests that the later "politique d'association" was more attentive toward local institutional conditions, which were, by the time of that change, however largely destroyed (see, for example, Weiskel, 1980, on the Baule).

${ }^{38}$ Crowder 1968. Beyond the literature cited here, a number of case-studies support this account
} 
marized in Table 1, I trace these differences back to diverging French and British administrative blueprints and ideologies, as well as to fewer administrative resources available to British colonial governments.

Table 1: Expected type of colonial rule

\begin{tabular}{lcc}
\hline \hline \multirow{2}{*}{$\begin{array}{l}\text { Precolonial } \\
\text { institutions }\end{array}$} & \multicolumn{2}{c}{ Colonizer } \\
\cline { 2 - 3 } & British & French \\
\hline Centralized & Indirect & Direct \\
Acephalous & Direct & Direct \\
\hline
\end{tabular}

\section{Historical Evidence}

The historiography of French colonial governance suggests that, wherever possible, the power of precolonial elites was crushed. ${ }^{39}$ Naturally, this lead to widespread armed resistance from the most powerful polities. ${ }^{40}$ Despite this hostility, the French colonial administration depended on native intermediaries to collect taxes, enlist forced labor, recruit soldiers, and maintain the local infrastructure. The responsible local chiefs were frequently appointed based on their loyalty to the French empire rather than their precolonial status. ${ }^{41} \quad$ They were stripped of their traditional authority and converted into colonial agents under the supervision of the commandants de cercle. ${ }^{42}$ These French administrators were shuffled around often enough to remain ignorant of local languages and customs. ${ }^{43}$ Instead, chiefs had

(e.g., Crowder and Ikime, 1970; Hailey, 1945), including well-designed analyses of French direct and British indirect rule over ethnic groups split by colonial borders. Asiwaju 1970; Miles 1994.

${ }^{39}$ Conklin 1997; Weiskel 1980.

${ }^{40}$ Crowder 1971b; Huillery 2010.

${ }^{41}$ Crowder 1968.

${ }^{42}$ Cohen 1971a,b; Suret-Canale 1988; Roberts 1929.

${ }^{43}$ Cohen 1971b; Crowder 1968. 
to speak French, inhibiting the continuous functioning of indigenous institutions ${ }^{44}$ and furthering the standardization of local governance.

The British choice of local governance institutions was different and aimed to use local rulers' legitimacy. The British thus collaborated with indigenous institutions, left them with much of their accustomed executive, legislative, and judiciary powers, and integrated their structure and personnel into the colonial state. ${ }^{45}$ British district officers had a primarily consultative role vis-à-vis indigenous rulers - they encouraged self-government and provided technical assistance. ${ }^{46}$

However, not all precolonial polities could be ruled indirectly. The degree to which British administrations could integrate traditional institutions crucially depended on their degree of precolonial centralization and pre-existing hierarchies. ${ }^{47}$ The idea of local self-government proved practicable where the British could co-opt centralized political institutions. But where political power was decentralized and in the hands of fragmented institutions foreign to the British, they pragmatically set up new governance schemes under the direct control of the administration that connected precolonial village-level elites to the center. ${ }^{48}$

Centralized precolonial institutions with multiple layers of hierarchies characterized the Kingdom of Buganda in Uganda, ${ }^{49}$ the Fulani Emirates in Northern Nigeria,${ }^{50}$ or the Ashanti confederation in the Gold Coast. ${ }^{51}$ The colonial administration made cheap use of these institutions by letting their rulers choose between

\footnotetext{
${ }^{44}$ Crowder 1971a.

${ }^{45}$ Hailey 1945; Lange 2009.

${ }^{46}$ Crowder 1968; Lugard 1965.

${ }^{47}$ Fortes and Evans-Pritchard 1940; Gerring et al. 2011; Hicks 1961.

${ }^{48}$ Crowder 1968; Hicks 1961; Tignor 1971.

${ }^{49}$ Reid 2002.

${ }^{50}$ Miles 1994.

${ }^{51}$ Wilks 1975.
} 
collaboration and death or exile. ${ }^{52}$ Under this threat of violence, prior elites often cooperated and shared their rents from ruling with the British. In exchange, they were able to preserve much of their previous power and autonomy. The resulting indirect rule featured two main characteristics. First, the British deployed only a minimal amount of administrative resources - just enough to monitor the actions of local elites and collect the rents of the colonial state. Second, local elites continued to enjoy many of their accustomed powers and presided over local governance entities that encompassed much of the institutions, hierarchies, and the territory of "their" pre-existing polity. ${ }^{53}$

Other regions lacked centralized precolonial structures but were instead ruled in a decentralized manner, for example, by village councils prevalent in the acephalous parts of southeastern Nigeria or the northern parts of Kenya and Uganda. ${ }^{54}$ Administering such areas posed substantial problems to British administrators who tried to implement a system of indirect rule. Without institutions above the village level, it was impossible to coerce one powerful ruler to gain control over a large population and territory. To rule efficiently, the colonial state thus had to build its own administrative system to link the colonial capital via the region and district level with each village. ${ }^{55}$

Whether staffed with colonial administrators or neo-"traditional" authorities such as the "warrant chiefs" lifted to power in southeastern Nigeria, ${ }^{56}$ the new system amounted to direct rule. The newly installed state agents were largely independent and partly ignorant about their subjects. They came to power at the

\footnotetext{
${ }^{52}$ Gerring et al. 2011.

${ }^{53}$ Crowder 1968; Perham 1937.

${ }^{54}$ Mair 1977.

${ }^{55}$ Crowder 1968; Fortes and Evans-Pritchard 1940; Hicks 1961; Tignor 1971.

${ }^{56}$ Afigbo 1972; Perham 1937.
} 
whims of the British colonial governments and did not depend on institutionalized ties to the population they ruled. ${ }^{57}$ In effect, this led to governance constellations that were similar to those observed in the French colonies.

Two main characteristics describe the resulting mode of direct local rule. First, the British colonial government employed a substantial amount of personnel and resources to run the administrative infrastructure that linked the colonial center with local populations. Second, the low-level indigenous elites presided over native governance entities that were much smaller in territorial and substantive scope than the indigenous governance units under indirect rule.

Of course, exceptions to the French and the British approach to local colonial rule exist. The French, for example, were never successful in fully overcoming the resistance of the Mossi Empire in Upper Volta, today's Burkina Faso. They finally settled on a cooperative relationship but reserved substantive administrative and judicial powers for themselves. ${ }^{58}$ Similar deviations from the "pure" British model marked the colonization of the Ashanti kingdom in Ghana. The kingdom was, after its violent submission in 1896 and the exile of the Asantehene, first put under direct rule. However, continuous nationalist mobilization of the Ashanti population convinced the British to allow traditional authorities to gradually resume their positions after $1919,{ }^{59}$ thus establishing indirect rule over the Ashanti.

\footnotetext{
${ }^{57}$ Hicks 1961; Tignor 1971. A certain tendency to confound traditional and nontraditional authorities as actors in schemes of indirect rule permeates the literature on indirect rule in Europe and Africa, for example, Hechter 2000; Mamdani 1996. From a theoretical standpoint, it is unclear how indirect rule can build upon nontraditional institutions that heavily rely on the central state to control their populations.

${ }^{58}$ Skinner 1970.

${ }^{59}$ Crowder 1968, 230-33; Tordoff 1968.
} 


\section{Determinants of French and British Styles of Colonial Rule}

Why is it then that the French chose the expensive paths of crushing precolonial polities and establishing a more direct form of rule? Or conversely, why did the British not follow a path of direct rule offering them greater powers to implement extractive colonial rule? I argue that three differences between the French and the British empires affected their relative costs and benefits of direct and indirect rule: the comparatively centralized style of metropolitan governance of the French, their transformative ideological agenda, and their greater access to administrative resources. ${ }^{60}$

First and prominent in the literature, the administrative architecture of colonizing powers shaped the one implemented in their colonies. Here, the centralized governance characterizing the French Third Republic greatly influenced its official policies. ${ }^{61}$ Already the military officers who conquered the French colonies established a strictly hierarchical system of administration. Assuming their role, the later civil administrators brought with them the centralizing tendencies of the French government. ${ }^{62}$ Contradicting the French administrative blueprint, the adaptation of indirect rule would have been relatively costly to implement and might have even raised demands for local autonomy elsewhere. By contrast, Great Britain's approach to governance at the turn of the nineteenth century was more diverse, including self-rule in the settler colonies of Canada and South Africa, and solving the nineteenth-century conflict over Irish "home rule" through Southern Irish autonomy

\footnotetext{
${ }^{60}$ For a parallel argument on the difference between mercantilist Spanish and liberal British colonialism, see Lange, Mahoney and vom Hau 2006. Gerring et al. 2011 name further factors that may explain direct rule, such as the aim for resource extraction, which do not substantially vary between the two empires.

${ }^{61}$ Cohen 1971a; Conklin 1997.

${ }^{62}$ Crowder 1968, 188.
} 
and the Northern Irish Parliament. ${ }^{63}$ Most closely connected to the African colonies was the British use of indirect rule in India. ${ }^{64}$ This experience of "heterogeneous contracting" between the center and peripheral units ${ }^{65}$ lowered the comparative costs of British indirect rule in Africa.

The administrative blueprints transferred to the colonies also came with differing ideologies that shaped colonial rule. French officials, as committed republicans, ${ }^{66}$ despised the existence of hereditary aristocrats whom Governor-General William Ponty scorned as "mostly nothing but parasites living on the population and existing without profit to the treasury." 67 Based on a fundamental premise of actual or potential equality of all people, ${ }^{68}$ the French aimed at assimilating their colonial subjects into a body of "100 million Frenchmen." 69 This necessarily entailed the replacement of precolonial elites and institutions through methods of direct rule. The British ideological backbone of local rule placed much more emphasis on the need for preservation of cultural differences between conquerors and colonial subjects. ${ }^{70}$ Combined with a lower aversion to traditional aristocrats, this reduced their ambitions at transforming colonial societies. Instead of being official policy, cultural transformation was "outsourced" to missionaries under the government's relatively weak control. As Gerring and colleagues note, realizing the transformative agenda of the French kind requires direct rule, whereas indirect rule empowers traditional leaders and inhibits radical change. ${ }^{71}$

\footnotetext{
${ }^{63}$ Bogdanor 2001.

${ }^{64}$ Fisher 1984.

${ }^{65}$ Nexon 2009.

${ }^{66}$ Cohen 1971a.

${ }^{67}$ Cited in Cohen $1971 b$.

${ }^{68}$ Crowder 1968, 167.

${ }^{69}$ Lewis 1962.

${ }^{70}$ Crowder 1968, 168.

${ }^{71}$ Gerring et al. 2011, 379.
} 
The third difference between the empires concerns the administrative resources at their disposal. We have already seen that French governments employed nine times as many European officers as their British counterparts. ${ }^{72}$ One important reason for this divergence involves the overall size of the British colonial empire, which exceeded that of the French by an order of magnitude. In 1921, France with its 40 million inhabitants ruled over 55 million colonial subjects across the globe, while 44 million British citizens ruled over approximately 400 million colonized subjects. ${ }^{73}$ If both empires could draw on a similarly big pool of well-educated potential colonial administrators in their metropolitan population, it comes as no surprise that French colonial administrations employed nine times more administrators per African subject than British colonial governments. This made indirect rule a pragmatic response to the lack of resources needed to establish and maintain direct control everywhere. ${ }^{74}$

The discussion of the mode of local rule in British and French nonsettler colonies in Africa suggests two main axes of variation in the indirectness of colonial rule. First, French colonial governments were comparatively hostile toward precolonial institutions and aimed to replace them with institutions that resembled the French administrative blueprint. The less republican and more resource-constrained British colonialists in turn championed local self-governance through pre-existing institutions to complement the central colonial government in a Lugardian scheme of "dual rule." As a result, more precolonial political institutions survived under British than French rule - the subject of this article's first empirical section. The British were

\footnotetext{
${ }^{72}$ Herbst 2000; Kirk-Greene 1980.

${ }^{73}$ Roberts 1929, xvi.

${ }^{74}$ See also Lugard 1965, 141.
} 
not able to rule indirectly where they confronted decentralized and fragmented precolonial institutions. In such regions, they set up more direct forms of colonial rule, employing more administrative effort and devolving less power to local indigenous authorities. I analyze this dynamic in the second empirical section.

\section{The Survival of Precolonial Institutions}

To test whether French colonial rulers crushed and replaced more precolonial political institutions than British colonial governments, I exploit data on the continuation of the lines of succession in 124 colonized African polities in the nineteenth and twentieth centuries. A survival analysis of the lines of succession shows that in each year, precolonial polities' lines of succession under French rule had a four-times higher risk of being terminated than those of polities under British rule. This difference persists in comparisons of polities across arguably arbitrary colonial borders.

\section{Panel Data on Precolonial Polities}

To analyze the survival of precolonial institutions under colonial rule, we need panel data on colonized polities. Currently used data on precolonial institutions in Africa, most prominently Murdock's Ethnographic Atlas ${ }^{75}$ are valuable for its detailed cross-sectional and geographical information, but lack the dimension of time. To fill this void, I digitize historical data on 124 African states before and during French and British colonial rule, collected by Stewart in his encyclopedia of African States and Rulers. ${ }^{76}$ First published in 1989 and updated since then, the encyclopedia enlists indigenous, colonial, and postcolonial states in Africa. Each entry comes

\footnotetext{
${ }^{75}$ Murdock 1959, 1967.

${ }^{76}$ Stewart 2006.
} 
with a short account of a state's history and a detailed enumeration of its rulers and capitals. ${ }^{77}$ In addition, Stewart lists the year of each polity's colonization, thus capturing the variation in the onset of colonial rule that resulted from colonizers' military advances into the interior of the African continent. These data originate from a comprehensive list of sources, among them historical case studies, the Journal of African History, and encyclopediae such as the Cambridge History of Africa.

The main information used in the empirical analysis is the continuation of a polity's line of succession in each year of the colonial occupation by either the British or the French empire. These data are available because Stewart continues to enlist polities' rulers - so they existed - throughout the colonial and postcolonial period (Figure 2). I take advantage of this coding and take the continuing line of succession in a precolonial state as a proxy for its institutional survival under colonial rule. In particular, I code the end of the line of succession in the year after which Stewart enlists no further rulers for the respective polity. ${ }^{78}$ While the survival of institutions is not always equivalent to the survival of its personnel, the dissolution of a political dynasty is a prominent indicator for the dismantling of the institutions they presided over. This is particularly relevant for precolonial polities in Africa, most of which were traditional regimes that derived authority and legitimacy from hereditary rule and the line of succession. ${ }^{79}$

The states covered by Stewart ${ }^{80}$ overwhelmingly belong to the class of centralized precolonial polities. As Appendix A1.1 demonstrates, settlement areas of ethnic

\footnotetext{
${ }^{77}$ In each year, a state has only one capital, but some capitals are relocated over time. I geocode all capitals via the geonames.org and maps.google.com APIs.

${ }^{78}$ This particular coding ensures that polities do not "die" if there is an interregnum without a ruler, as there sometimes was.

${ }^{79}$ Weber 1958.

${ }^{80}$ Stewart 2006.
} 


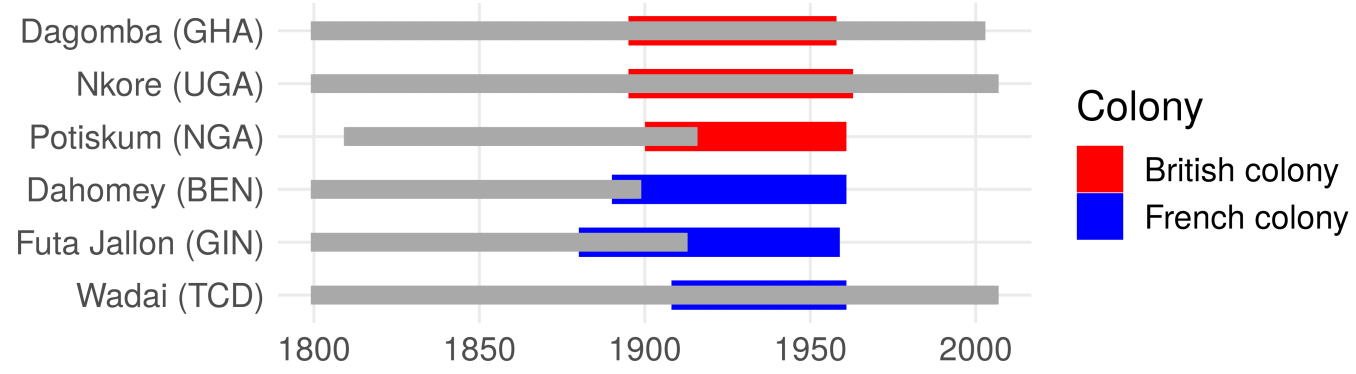

Figure 2: Lines of succession in six precolonial states 1800-2000.

Note: Censored before 1800. Gray rectangles denote the observed lifespan of each line of succession. Red and blue rectangles denote the colonial period. Abbreviations of colonies' postcolonial name in parentheses.

groups that were coded as precolonial states (acephalous societies) by Murdock, ${ }^{81}$ feature a polity in Stewart's data in 60 percent (4\%) of all cases. This is not surprising, given that Stewart was primarily interested in collecting polities' rulers, which are hardly identifiable in acephalous societies. Furthermore, acephalous societies lack the institutions to produce traces uncovered by Stewart's sources. ${ }^{82}$

This type of bias makes the data unsuitable for providing a representative description of all precolonial polities in Africa. However, valid inferences about differences in polities' survival rates under British and French colonial rule are possible if the coding is not biased by the type of colonial rule. Stewart's data show few signs of such bias. A set of analyses in Appendix A1.1 suggests that Stewart did not record less states or much different state histories in areas and ethnic groups colonized by the British. If anything, less information on precolonial polities seems to be available from French colonies. Information likely got lost from those polities that did not survive colonization. If at all, this biases the analysis against the hypothesis, that is, toward a higher probability of survival under French rule.

\footnotetext{
${ }^{81}$ Murdock 1959.

${ }^{82}$ See, for example, Scott 2017. Because the sample of polities is biased toward centralized polities, I cannot estimate an unbiased effect of precolonial centralization on polities' survival.
} 


\section{Analysis}

Figures 3 and 4 provide descriptive evidence for a large difference in the survival rates of polities under French and British rule. Zooming in on West Africa, we see the map in Figure 3 suggests that in French West Africa only a few polities reached independence with their local leadership intact. Those that did were mostly located in the far-away regions of Niger (Zinder) and Chad (e.g., Wadai), or were too strong to be made submissive, like the Mossi kingdoms mentioned earlier. The picture looks different for the British colonies in the same area. In the Gold Coast, all coded polities survived, though not always unscathed as the Ashanti kingdom illustrates. In Nigeria, where the nineteenth century Fulani Jihad created a large number of emirates, fewer polities withstood colonial conquest and rule, but proportionally many more than under French rule. A simple comparison of the proportions of colonized polities that reached independence supports this impression: 26 percent of polities colonized by the French and 60 percent colonized by the British survived colonial rule, the difference being highly statistically significant (see Figure 4).

This difference remains stable once I model the end of lines of succession of all colonized polities during the colonial period in a Cox Proportional Hazard Model. Each polity enters the data set at the point of colonization by either the British or the French and leaves the data set either with the end of its line of succession or with its colony's independence. All polities included in the model are listed in Appendix Table A5 with the respective start and end years in the sample.

The Cox model includes a set of covariates geographically attributed to polities via the location of their capital. In particular, I first include a vector of (1) baseline controls comprising the local population density, the polity's age, its distance to the 


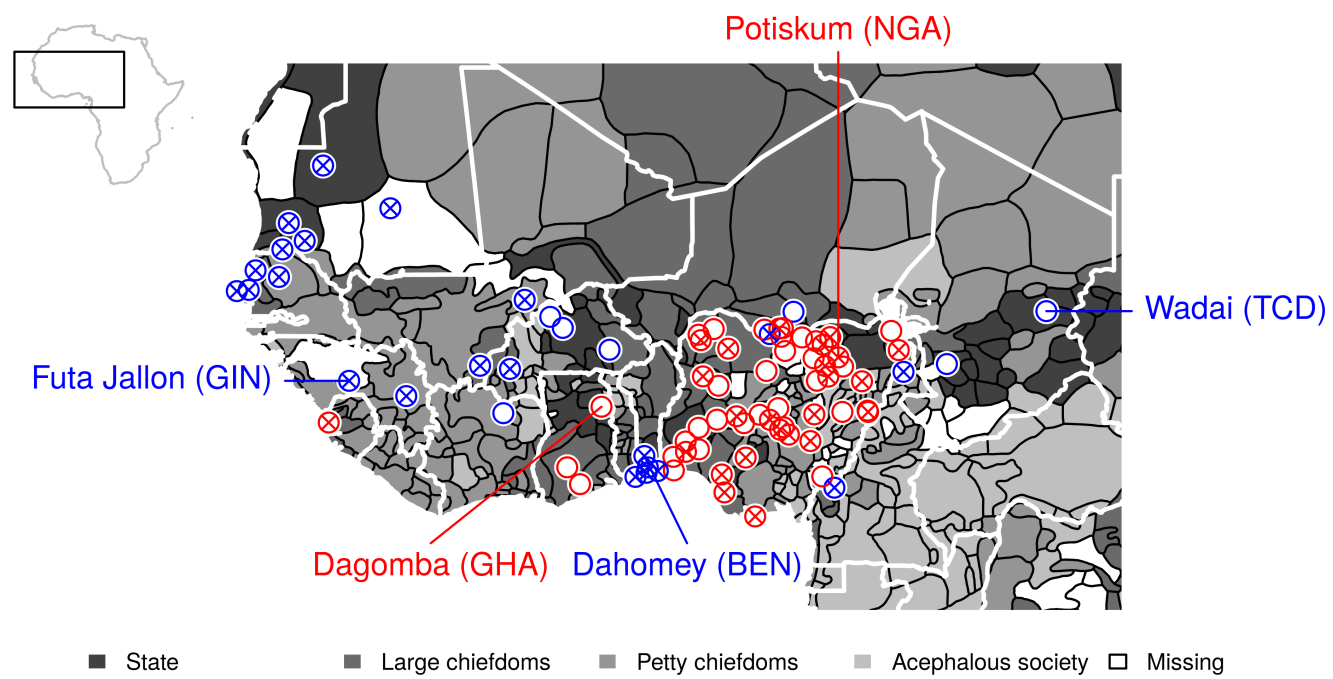

Figure 3: Map of all colonized polities in West Africa

Note: Polities marked by a cross saw their line of succession terminated before their countries gained independence. For a full map of Africa, see Appendix A2.

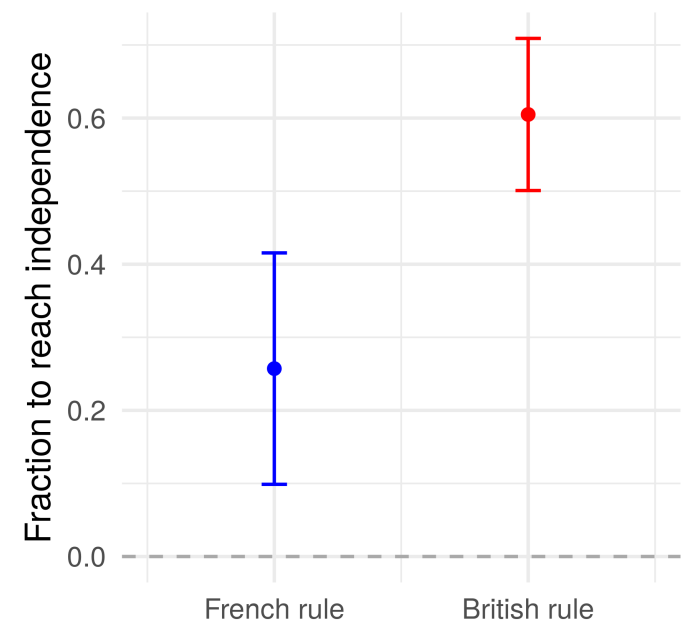

Figure 4: Fraction of colonized lines of succession to survive until the year of independence from colonial rule

Note: Error bars denote $95 \%$ confidence intervals from a linear regression without controls. For a full set of cross-sectional analyses, see Appendix A2.2. 
coast and nearest navigable river, ${ }^{83}$ and a simple linear time trend. To control for observable differences between the regions colonized by the French and the British, I add a vector of natural characteristics around the area of a polity's capital, ${ }^{84}$ and finally a vector of characteristics of the ethnic group ${ }^{85}$ in the settlement area a polity's capital is located in.

Table 2: British vs. French rule and the demise of precolonial polities: Cox Proportional Hazards

\begin{tabular}{lccc}
\hline \hline & \multicolumn{3}{c}{ End of line of succession } \\
\cline { 2 - 4 } & $(1)$ & $(2)$ & $(3)$ \\
\hline British rule & $-1.459^{* * *}$ & $-1.523^{* * *}$ & $-1.787^{* * *}$ \\
& $(0.352)$ & $(0.388)$ & $(0.600)$ \\
Population $/ \mathrm{km}^{2}(1880, \log )$ & $-0.016^{* *}$ & $-0.031^{* * *}$ & -0.012 \\
& $(0.008)$ & $(0.010)$ & $(0.015)$ \\
Distance to coast $(\log )$ & & & \\
& $-0.229^{* * *}$ & $-0.217^{* *}$ & -0.104 \\
& $(0.088)$ & $(0.095)$ & $(0.134)$ \\
Distance to river $(\log )$ & & & 0.202 \\
& $-0.134^{*}$ & 0.035 & $(0.239)$ \\
Polity age (log) & $(0.077)$ & $(0.143)$ & 0.121 \\
& & & $(0.157)$ \\
Year & 0.062 & 0.025 & $-0.769^{* * *}$ \\
& $(0.091)$ & $(0.115)$ & $(0.279)$ \\
& & & \\
\hline Nature controls: & $-0.423^{* *}$ & $-0.682^{* * *}$ & yes \\
Ethnic controls: & $(0.188)$ & $(0.175)$ & yes \\
Observations & & & 4,581 \\
$\mathrm{R}^{2}$ & no & yes & 0.009 \\
Max. Possible $\mathrm{R}^{2}$ & no & no & 0.055 \\
Log Likelihood & 5,208 & 4,902 & -108.471 \\
\hline \hline
\end{tabular}

Notes: Cox Proportional Hazard models. Standard errors are clustered on the polity-level. Nature controls consist of median altitude and slope, mean annual temperature, precipitation and evapotranspiration, the ratio of the two, agricultural suitability, and soils' suitability for cash crop production. Ethnic controls consist of the reliance on agriculture and pastoralism, as well as the intensity of agricultural activities. Significance codes: ${ }^{*} \mathrm{p}<0.1 ;{ }^{* *} \mathrm{p}<0.05 ;{ }^{* * *} \mathrm{p}<0.01$.

\footnotetext{
${ }^{83}$ Data on rivers come from Jedwab and Moradi 2016.

${ }^{84}$ In particular, its altitude, ruggedness, temperature, average precipitation, evapotranspiration, the ratio of its evapotranspiration and its precipitation, as well as its suitability for cash crop production (all from FAO, 2015) and agriculture in general. Ramankutty et al. 2002. See also the discussion in the second empirical part.

${ }^{85}$ These are the reliance of local ethnic groups on agriculture and pastoralism, as well as the intensity of their agricultural activities. Murdock 1959.
} 

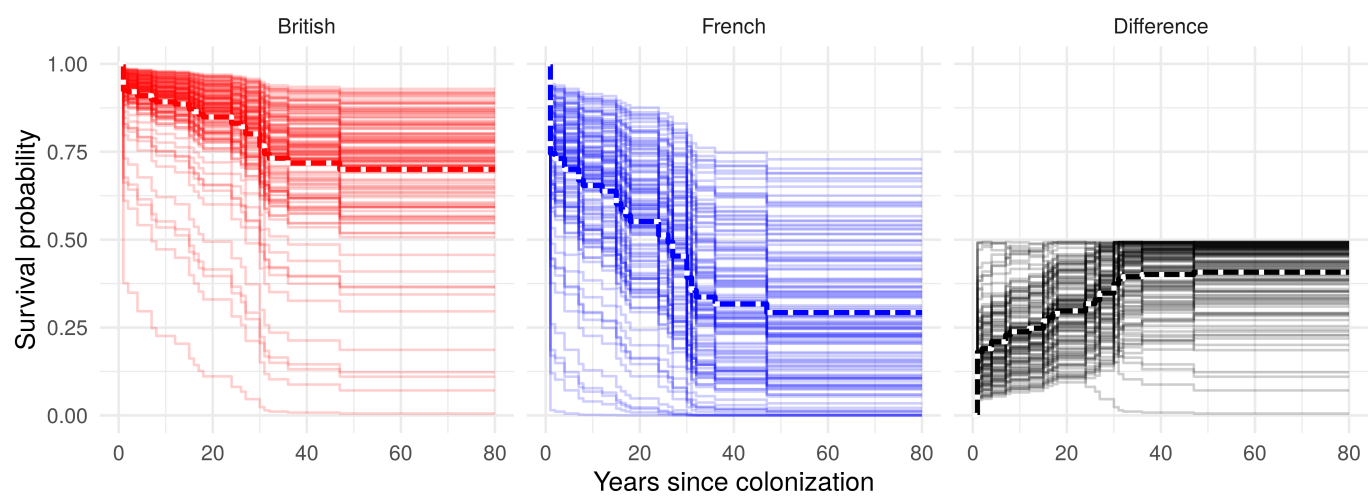

Figure 5: Survival curves as predicted for all polities under either British or French rule

Notes: Based on Model 1 in Table 2, the Figure plots the predicted survival of every polity under British and French colonial rule. The third panel plots the polity-level difference between these two predictions. Thin lines plot the polity-level predictions, bold lines plot the average across all predictions.

Table 2 reports the results. The transformation of the coefficients of BRITISH RULE into hazard ratios shows that the lines of succession under British rule had, in every year, a probability of ending that was about a quarter of that of a polity under French rule. The gap between the empires increases in models 2 and 3 with additional controls. This suggests that, if at all, the British settled in areas with a disposition for more frequent extinctions of precolonial polities. The differential yearly hazard rate between the two empires translates into a large and increasing toll that precolonial polities took from French colonization, visualized by the survival curves in Figure 5. Because the imperial domination of the continent ended after approximately eighty years, the model predicts only one out of three polities under French rule to have survived. Under British rule the toll is also substantive but much lower with a 70 percent chance of survival, largely equivalent to the raw comparison discussed initially.

To test the robustness of these findings, I conduct a series of sensitivity analyses in Appendix A2.1. In particular, I show that the results are not driven by (1) a 
potentially overwhelming weight of some colonies (e.g., Nigeria with its many Fulani emirates) by giving each colony equal weight; (2) differential temporal dynamics of the French and British colonization by stratifying the regressions by year; (3) the local disease environment; (4) miss-specified clustering of standard errors, clustering instead not at all, on the colony, and ethnic group level; or (5) the chosen functional form of the models, instead using a simple linear hazard model. (6) The results are mostly robust to dropping observations of single colonies with the exception of dropping Nigeria in the fully specified model, where point estimates remain stable but standard errors increase. A final analysis (7) focuses on the effect of British and French colonial rule on the average tenure time of rulers compared to tenure times before colonization in the same polity. The effect associated with French colonization on the yearly risk of a ruler's deposition or death is 1.5 times the effect associated with British colonization (see Appendix A2.4).

Polities' survival in (coastal) West Africa. So far, the main identifying assumption of the model is that colonization by either the French or the British was, conditional on covariates, as if random. This assumption may be difficult to uphold in the face of colonies' diversity in East and West Africa. A series of further analyses in Appendix A2.5 therefore successively limits the sample of compared polities to ever-smaller and homogeneous regions, first polities in West Africa and second to those in the coastal colonies in West Africa only. Figure 6 shows the results which are well in line with the baseline estimates plotted to the left.

Finally, I follow recent studies that use colonial borders for identification purposes $^{86}$ and estimate the effect of British rule across arguably arbitrary borders in

\footnotetext{
${ }^{86}$ see Cogneau and Moradi 2014; McCauley and Posner 2015.
} 
West Africa that run perpendicular to the coastline. ${ }^{87}$ These borders were drawn in the aftermath of the quick scrambling for territory after 1885 when colonial armies moved from the coast to the interior parts of the continent, which explains their location and their approximate ninety-degree angle to the coast. ${ }^{88}$ Like many other colonial borders in Africa, the respective borders followed no historical precedent ${ }^{89}$ and cut through ethnic groups and political entities. ${ }^{90}$ While they were in some places adjusted by a few kilometers, ${ }^{91}$ there is no historical evidence that precolonial capitals selected into or out of British rule.

Because the spatial sparseness and clustering of precolonial capitals (see Figure 3) inhibits the estimation of a regression discontinuity at the border, I use the full sample of polities from the coastal West African colonies and estimate a Cox Proportional Hazard Model that is stratified by each polity's closest perpendicular empire border. Similar to border fixed effects, this ensures that we compare only polities across these borders. This last analysis yields estimates of the effect of British rule that are larger than the one reported at baseline. With the smaller sample and border strata reducing the degrees of freedom, $p$-values of the estimate of British rule drop to $p<.1$ and the size of the coefficient increases substantively as I add the vectors of control variables. These patterns support the baseline results.

The unique data from Stewart's encyclopedia of African states and rulers ${ }^{92}$ show that precolonial polities' demise was much more frequent under French than under British colonial rule. This result supports the argument that the French ruled more

\footnotetext{
${ }^{87}$ From west to east: Côte d'Ivoire-Gold Coast-French Togo Mandate-Dahomey-NigeriaCameroon.

${ }^{88}$ Wesseling 1996.

${ }^{89}$ Brownlie 1979; Herbst 2000

${ }^{90}$ Asiwaju 1970; Englebert, Tarango and Carter 2002.

${ }^{91}$ Brownlie 1979; Griffiths 1986.

${ }^{92}$ Stewart 2006.
} 


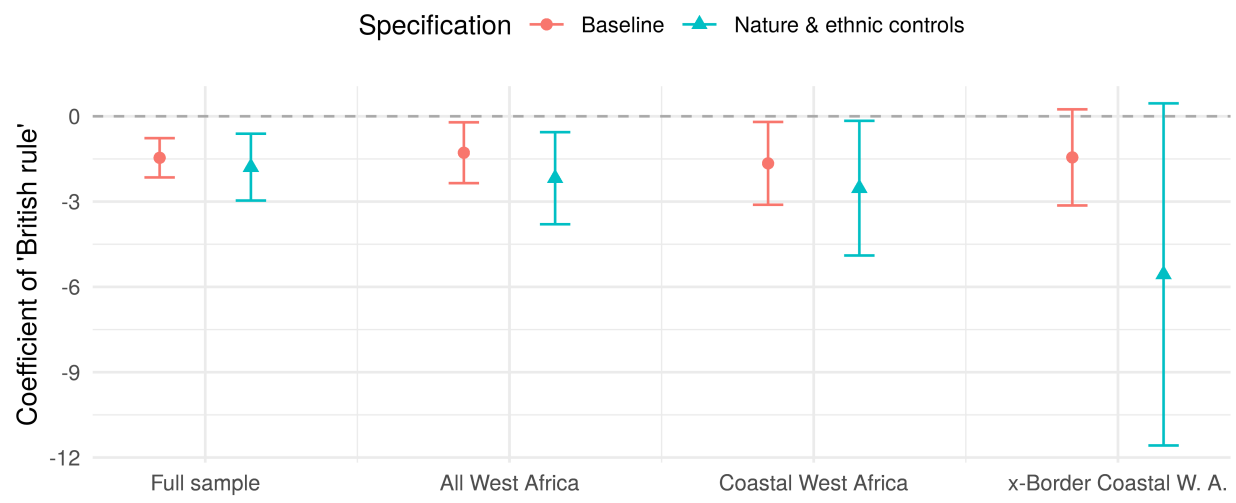

Figure 6: Marginal effect of British rule on the end of polities' line of succession in West Africa

Notes: Full sample estimates from Table 2. "x-Border Coastal W.A." reduces the sample to coastal colonies in West Africa and stratifies estimates by the border closest to each polity.

directly and against pre-existing institutions than the British, who favored local self-government through traditional institutions. However, the focus on the survival of centralized polities masks variation in the schemes of colonial governance set up in regions with and those without such pre-existing institutions.

\section{Precolonial Institutions and Indirect Rule}

As the theoretical discussion outlined, there are two observable facets to indirect rule: the colonial power's administrative effort and local traditional institutions' power. The more local indirect rule is, the less administrative effort the central government employs to an area and the more power remains in the hands of local governments that are built upon pre-existing institutions. To provide evidence on indirect rule as complete and systematic as the available data allow, I shed light on both dimensions. All data (see Table 3) come from archival administrative reports from eight British colonies, chosen as a function of the availability of the respective data and excluding the settler colonies in Southern Africa and from Huillery for 
French West Africa. ${ }^{93}$ Appendix A1.2 lists additional details on the sources and coverage of the data.

Table 3: Data on the indirectness of colonial rule: Overview

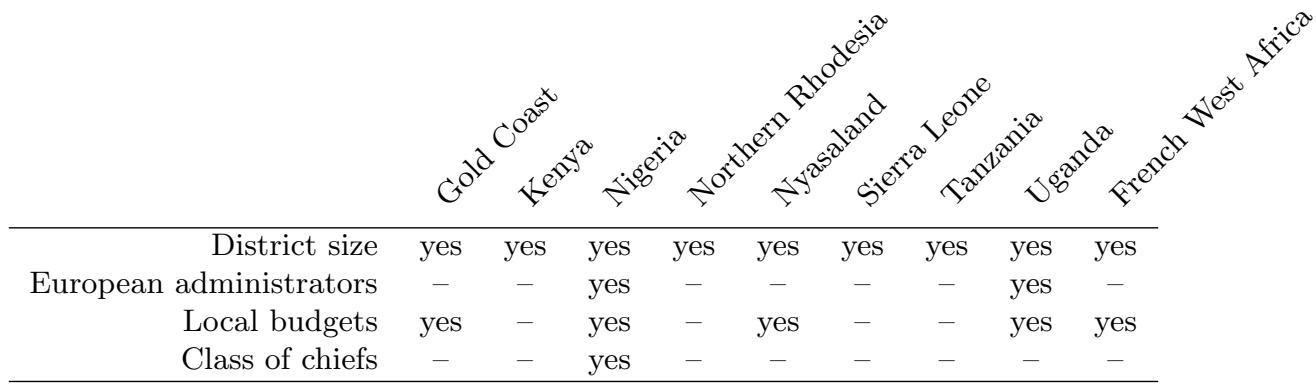

The first dimension of indirect rule concerns the local administrative effort employed by the colonizing government. More indirect rule comes with less administrative effort, measured in two ways:

1. Size of districts. This is the simple area of districts, net of water surface $\left(N_{G B}=294 ; N_{F}=114\right)$. Each district needs a minimal level of administrative resources, most importantly a district officer or commandant de cercle. Thus, dividing a region into more and thus smaller districts requires more administrative resources. Furthermore, smaller districts come with a lower distance between headquarters and the population. ${ }^{94}$ Given the importance of administrative tours ${ }^{95}$ this implies more frequent visits to any village and more direct rule.

2. European administrators. This measure draws on data on the number of British administrators employed at the local level. Unfortunately, such districtlevel officer lists are scarce, so the sample is reduced to Nigerian provinces and

\footnotetext{
${ }^{93}$ Huillery 2009.

${ }^{94}$ For example, Grossman and Lewis 2014; Grossman, Pierskalla and Dean 2017.

${ }^{95}$ Herbst 2000.
} 
districts in Uganda $(N=35)$. More immediately capturing the previous point, more indirect rule comes with fewer colonial officers posted to an area.

Two measures cover the flipside of indirect rule, the power of the traditional institutions through which schemes of indirect rule were carried out: native treasury budgets and Nigerian chiefs' power.

Table 4: Summary of native treasury data

\begin{tabular}{ccccccc}
\hline \hline Colony & Districts & Start & End & No. of years & Avg. revenue & Avg. expenditure \\
\hline Gold Coast & 29 & 1949 & 1951 & 3 & 9.92 & 9.18 \\
Nigeria & 86 & 1931 & 1939 & 9 & 3.12 & 3.04 \\
Nyasaland & 19 & 1934 & 1955 & 17 & 1.29 & \\
Uganda & 13 & 1934 & 1956 & 22 & 8.86 & 10.60 \\
\hline
\end{tabular}

Notes: Note that the number of observations in the data might be smaller than the number of existing districts, because some budget reports report numbers above the district level (e.g. Buganda, Uganda).

1. Native treasury budgets. As I argued ealier, British colonial governments co-opted strong and hierarchical institutions because they generated rents in a centralized manner and allowed for relatively cheap top-down policy implementation. Thus, indirectly ruled areas should feature native treasuries with larger budgets, both on the revenue and expenditure side. The respective data come from the British "Annual Departmental Reports" for the Gold Coast (Ghana), Nigeria, Nyasaland (Malawi), and Uganda (1931-1956). ${ }^{96}$ The reports include budget totals as well as detailed breakdowns of revenues and expenditures into subcategories (see Appendix A4.1).

In total, the collected data cover native treasuries in 148 districts across the four colonies and a varying number of years. ${ }^{97}$ To avoid biases emerging from

\footnotetext{
${ }^{96}$ The data collection proceeded in two stages. I first processed the scans of the tables to extract their content automatically. I then cleaned each entry in every table to ensure that no errors affect the results. See Appendix A1.3.1 for details.

${ }^{97}$ This collection is similar to the cross-sectional data on native administrations' revenues collected by Bolt and Gardner 2018.
} 


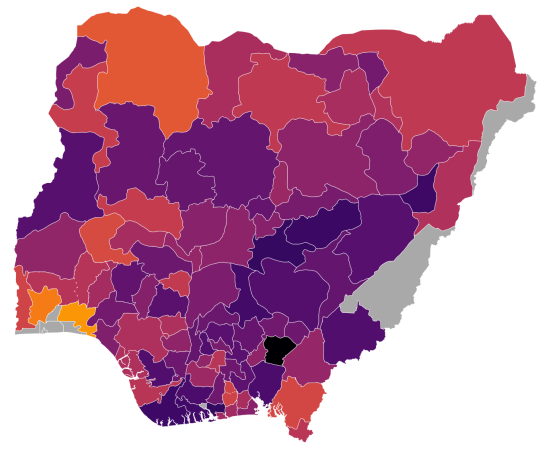

(a) Nigeria 1931-1939

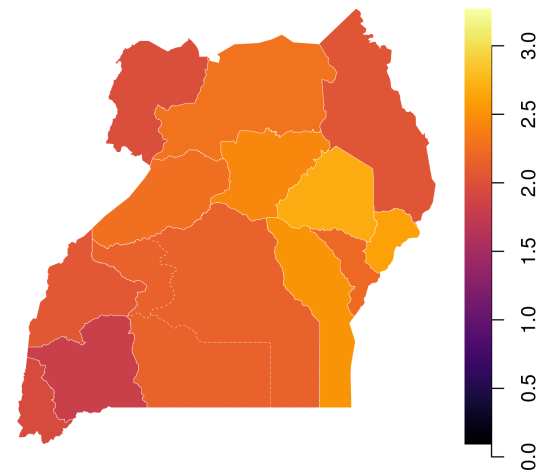

(b) Uganda 1934-1956

Figure 7: Per-capita revenues of native treasuries (logged; $2016 £$ )

Notes: Aggregated to the district level and averaged over all observed years. Dotted lines indicate borders along which I aggregate districts for the analysis of local budgets (see discussion in text).

an unbalanced panel, ${ }^{98}$ I link native treasuries to the colonial districts introduced earlier and average the budget data for each district across all years (see Figure 7). ${ }^{99}$ If a budget in one year covers more than one district (e.g., the budget of the Kabaka of Buganda, which covered an entire region), I aggregate the data to the highest spatial "denominator" in all years, again for reasons of spatio-temporal consistency.

2. The power of Nigerian chiefs. The second indicator of the power in the hands of local authorities consists of the rights and recognition chiefs received in Nigeria, measured through their official "class." "First class" chiefs possessed the greatest powers and authority over subsidiary chiefs. "Third class" chiefs had a limited realm in terms of the population they ruled and the rights they

\footnotetext{
${ }^{98}$ Because reporting standards of the British administrations varied across colonies and over time, the length of the time series available for each colony varies considerably (see Figure A6). Furthermore, native treasuries were at times newly created or merged, leading to a variation in spatial units that is difficult to track over the years, since no time-varying information on native administrations' boundaries is available.

${ }^{99}$ I also explore two alternative ways to deal with this caveat: (1) weighted panel regressions, and (2) hierarchical modeling. See Appendix A3.1.
} 
enjoyed. $^{100}$ Based on a list compiled by the British War Office in $1929,{ }^{101}$ the class of the highest-ranking chief in each district serves as an indicator for indigenous institutions' power and thus local indirect rule.

While the data encode diverse aspects of local colonial governance, the four outcomes correlate with each other (correlation coefficient of between .38 and .65; see Appendix A1.4). For example, larger districts feature fewer European administrators per capita, more revenues by native treasuries, and their chiefs have more power. This suggests that the ensemble of all four indicators comprehensively measure the indirectness of local colonial rule.

Precolonial institutions. To test the argument that the local level of precolonial political centralization determined the degree of indirect colonial rule, detailed crosssectional data of the degree of centralization of local institutions at the time of the colonial conquest are needed. The best source for such data is the Ethnographic Atlas compiled by Murdock. ${ }^{102}$ Based on early ethnographic research, the atlas classifies the levels of administrative hierarchies of ethnic groups' precolonial political institutions. The coding ranges from 0 to 4 levels, from no political authority beyond the community, via petty chiefdoms and larger chiefdoms, to states and large states. Using the spatial information from Murdock's ethnic map ${ }^{103}$ the average precolonial centralization of each district's area measures the number of administrative levels that could be used for indirect rule by the colonial power.

\footnotetext{
${ }^{100}$ Lugard 1965, 212 and Appendix A1.4

${ }^{101}$ United Kingdom War Office 1929. The list covers Northern Nigeria for the year 1928 and Southern Nigeria in the year 1924.

${ }^{102}$ Murdock 1967.

${ }^{103}$ Murdock 1959; Nunn and Wantchekon 2011. The matched data are available here: http: //worldmap.harvard.edu. Michalopoulos and Papaioannou 2013 provide a slightly different match between the two data sources. Using their mapping does not changes the results (see Appendix A3 and A4).
} 
With this coding of hierarchical levels, the data are better able to capture the ease with which different political systems could be ruled indirectly than other data sets, such as maps of state histories ${ }^{104}$ or Stewart's encyclopedic data of precolonial polities and their rulers. ${ }^{105}$ Stewart's data come with the additional disadvantage that only the coordinates of polities' capitals but not their borders are known. This makes their attribution to relatively small spatial units such as districts subject to large errors where precolonial states were carved up into multiple districts subject to an overarching native authority. Furthermore, his data are likely incompleteonly 60 percent of groups coded by Murdock as a large precolonial state feature a polity in Stewart's data in 1885 . However, I check the consistency of the results with Steward's data later.

\section{Empirical Strategy}

With this data on district-level colonial and traditional rule at hand, I estimate the effect of precolonial centralization on the various indicators of indirect rule in a simple linear modeling framework:

$$
\mathrm{y}_{i, p, c}=\alpha_{c}+\beta_{1} \text { PRECol. CEntralization } i+\boldsymbol{X}_{1} \boldsymbol{\Lambda}_{i}+\boldsymbol{X}_{2} \boldsymbol{\Omega}_{i}+\boldsymbol{X}_{3} \boldsymbol{\Psi}_{i}+\epsilon_{i, p}
$$

In particular, I reduce the variation in PRECOL. CENTRALIZATION $i$ exploited by each model to within-colony variation by using colony-fixed effects $\alpha_{c}$. In specifications that compare patterns of indirect rule in British and French colonies, the models include the interaction term PRECOL. CENTRALIZATION $i \times \mathrm{FRENCH}_{c}$. In these cases, I do not add the constitutive term $\mathrm{FRENCH}_{c}$, which is redundant given the colony fixed effects $\alpha_{c}$. Since precolonial centralization is not randomly assigned

\footnotetext{
${ }^{104}$ For example, Depetris-Chauvin 2014.

${ }^{105}$ Stewart 2006.
} 
to districts $i$, I successively include three vectors of control. First, vector $\boldsymbol{\Lambda}_{i}$ captures only the baseline characteristics of a district: the average spatial density of the population of the district and the ethnic groups that inhabit it, ${ }^{106}$ as well as a district's' distance from the coast and closest navigable river, all logged. ${ }^{107}$ Second, $\boldsymbol{\Omega}_{i}$ controls for what I call the "natural" attributes of a district: its altitude, ruggedness, temperature, average precipitation, evapotranspiration, the ratio of its evapotranspiration and its precipitation, as well as its suitability for cash-crop production ${ }^{108}$ and agriculture in general. ${ }^{109}$ Third, I add an "ethnic" vector of controls $\boldsymbol{\Psi}_{i}$ for the socioeconomic characteristics of districts that might cause strong local governments and precolonial centralization. These are local ethnic groups' reliance on agriculture and pastoralism as well as the intensity of their agricultural activities. ${ }^{110}$ aggregate these variables to the district level by taking their area-weighted means. French-British models include interactions of all controls with a French dummy. Last, standard errors are clustered on the provincial, thus first-level administrative unit level $p$ to account for potential dependencies among districts in the same region.

\section{Results}

The presentation of the results follows the structure of the data. A first set of analyses finds that administrative effort, measured through the size of districts and the

\footnotetext{
${ }^{106}$ Calculated with data from Goldewijk, Beusen and Janssen 2010. This is the mean population density in the settlement areas of the ethnic groups whose settlement areas overlap with a district. The mean is weighted by the area of overlap.

${ }^{107}$ All may directly relate to indirect rule and the level of precolonial centralization: for example, in densely populated areas, we would expect more centralization and smaller districts that keep the size of the population constant. In areas removed from the coast, colonial rule came later, less forceful, and more indirectly. Data on navigable rivers comes from Jedwab and Moradi 2016.

${ }^{108}$ All from FAO 2015. I create the index of cash crop suitability by taking the local maximum of soils' suitability for the eight most important cash crops: cocoa, coffee, cotton, groundnut, oil palm, sugarcane, tea, and tobacco.

${ }^{109}$ Ramankutty et al. 2002.

${ }^{110}$ Murdock 1967.
} 
local number of British administrators, decreases in the centralization of precolonial institutions. A second set of analyses completes the picture and shows that the power of indigenous or "native" administrations increases in the level of precolonial centralization. While these relationships are overall robust for British colonies, the data from French colonies exhibit no significant or even opposite associations. Together, the results support the argument that precolonial centralization was a strong determinant of indirect rule in the British, but not French colonies.

\section{Evidence on Administrative Effort}

The size of districts. Districts were larger in areas with strong precolonial institutions in British but not in French colonies. The estimated effect of precolonial centralization on the size of British districts is substantial: a move from an acephalous society to a precolonial state, that is, an increase in the value of PRECOL. CENTRALIZATION by 3 , is associated with an increase in the size of districts by between 35 and 54 percent (Table 5). The reverse relationship appears in French West Africa, where the data suggest that an increase in the level of precolonial centralization by the same three levels decreased districts' size by about 45 percent (Figure 8). ${ }^{111}$ Because larger districts correspond to lower levels of administrative effort that the colonizers exerted, this is evidence that centralized pre-existing institutions facilitated British indirect rule.

This relationship between indirect colonial rule and the size of local governance units remains robust to a number of permutations of the model. A set of sensitivity analyses yields that the results are (1) not driven by very big or very small districts,

\footnotetext{
${ }^{111}$ Because district sizes are logged, these percentage changes result from calculating $(\exp (\beta * 3)-$ 1) $* 100$.
} 
Table 5: Precolonial centralization and the size of districts

\begin{tabular}{lccc}
\hline \hline & \multicolumn{3}{c}{$\log ($ District Area $)$} \\
& $(1)$ & $(2)$ & $(3)$ \\
\hline Precol. centralization & $0.143^{* *}$ & $0.098^{* *}$ & $0.131^{* * *}$ \\
& $(0.065)$ & $(0.048)$ & $(0.049)$ \\
& & & \\
Precol. centralization $\times$ French & $-0.304^{* *}$ & $-0.294^{* * *}$ & $-0.334^{* * *}$ \\
& $(0.120)$ & $(0.108)$ & $(0.106)$ \\
& & & yes \\
Colony FE: & yes & yes & yes \\
Baseline controls: & yes & yes & yes \\
Nature controls: & no & yes & yes \\
Ethnic controls: & no & no & 9.14 \\
Mean DV & 9.11 & 9.14 & 400 \\
Observations & 404 & 400 & 0.721 \\
Adjusted R & 0.673 & 0.717 & Base-
\end{tabular}

Notes: OLS models. Standard errors are clustered on the province-level. Baseline controls include the local population density, ethnic groups' population density, and the distance to the coast as well as the closest navigable river. Nature controls consist of the local altitude and slope, mean annual temperature, precipitation and evapotranspiration, the ratio of the two, agricultural suitability, and soils' suitability for cash crop production. Ethnic controls are the reliance on agriculture and pastoralism, as well as the intensity of agricultural activities. Additionally, all covariates are interacted with 'French rule'. Significance codes: ${ }^{*} \mathrm{p}<0.1 ;{ }^{* *} \mathrm{p}<0.05 ;{ }^{* * *} \mathrm{p}<0.01$.

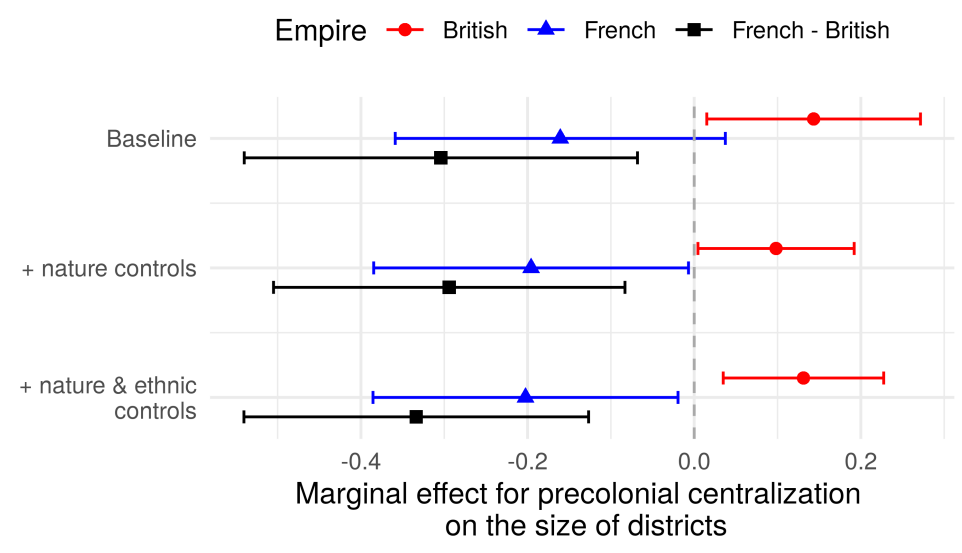

Figure 8: Marginal effect of precolonial centralization on district size Note: Based on models 1-3 in Table 5. 
(2) not due to a potential overweighting of colonies with many districts such as Nigeria, and (3) robust to including a vector of co-variates that control for the disease environment of a district, which might relate to precolonial statehood and colonial administrative difficulties. The results are robust to a colony-level jackknife, and consistent if I use the slightly different coding of precolonial centralization ${ }^{112}$ or the newly collected data on precolonial polities as a measure of precolonial centralization. Districts that featured a capital city in 1885 were approximately 65 percent bigger in British colonies, but of average size in French colonies.

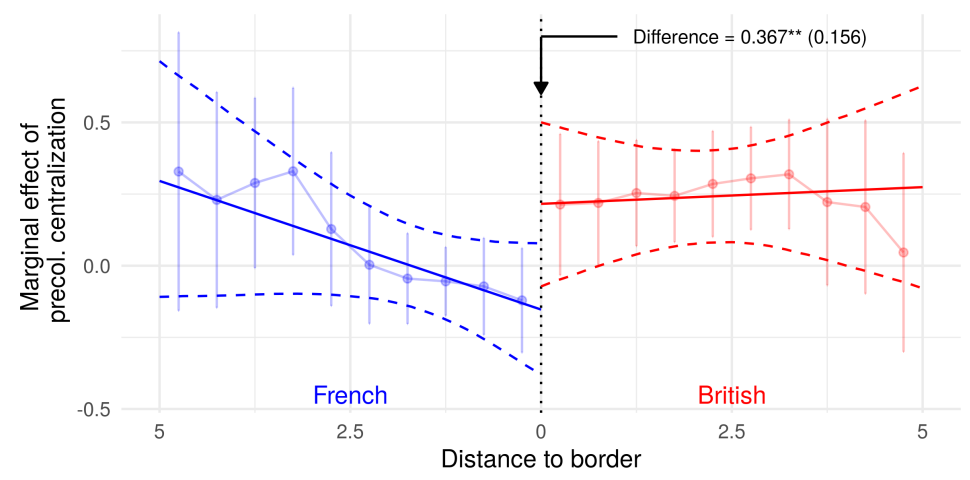

Figure 9: Regression discontinuity plot of the effect of precolonial centralization on districts' size at French-British borders perpendicular to the West African coastline Notes: Solid lines illustrate the results from a linear trend-model with a bandwidth of five decimal degrees. Transparent point estimates plot the effect of precolonial centralization in .5 decimal degree bins of the distance toward the French and British sides of the borders. See Appendix A3.3 for all details.

Imbalances in observables suggest that the divergence of precolonial centralization's effects in British and French colonies might be driven by endogenous colonization choices of both empires. To address this caveat, I exploit borders between Nigeria and Dahomey (Benin) as well as between Côte d'Ivoire and the Gold Coast (Ghana) that run perpendicular to the West African coastline. The borders' location was determined by the post-1885 race toward the interior of the continent and

\footnotetext{
${ }^{112}$ From Michalopoulos and Papaioannou 2013.
} 
can therefore be regarded as drawn in a quasi-random manner. ${ }^{113}$

Fully presented in Appendix A3.3, the regression discontinuity design identifies the difference in the effect of pre-existing institutions on districts' sizes at the FrenchBritish borders. Using grid cells within a bandwidth of five decimal degrees as the unit of analysis ${ }^{114}$ and improving but not fully securing balance on pre-treatment covariates (see Table A18), ${ }^{115}$ the analysis supports the conclusion drawn from the baseline model. As Figure 9 illustrates, the estimated difference is statistically significant $(p<.05)$ and shows that precolonial centralization had an effect on district sizes .37 log-points smaller in French than in British colonies. ${ }^{116}$

I test this result's robustness with additional control variables to counter the remaining imbalances in the data, using various grid-cell sizes, and dropping cells close to the border to account for potentially endogenous local border adjustments mentioned by Griffiths. ${ }^{117}$ These variations do not significantly affect the results. Varying the bandwidth, the baseline results are statistically insignificant below a cutoff of 1.5 decimal degrees to the border and are stable at larger cutoffs. In sum, the analysis shows that potentially endogenous spatial sorting of colonizers does not explain the patterns of indirect rule observed in the French and British colonies.

European administrators. In addition to district sizes, I draw on data on British administrators' spatial distribution to measure the extent of indirect rule. Because

\footnotetext{
${ }^{113}$ Cogneau and Moradi 2014; Wesseling 1996.

${ }^{114}$ I use grid cells as the unit of analysis here as the number of districts in an area by definition decreases with their size. In the RD-design, this would lead to a jump in the number of observations at the border, which may bias the results. Grid cells have a size of .0833 decimal degrees in the baseline RDD-analysis, and a varied in a robustness check.

${ }^{115}$ At a bandwidth of 5 decimal degrees around the borders balance is best with imbalances affecting grid cells' distance to the coast, altitude, and suitability for agriculture.

${ }^{116}$ The regression discontinuity design identifies only this difference but not the baseline effect of centralization on districts' size in British colonies.

${ }^{117}$ Griffiths 1986.
} 
such data are less abundant, I have access to the number of British administrators in only the twenty-two Nigerian provinces and twelve Ugandan districts. The data support the argument. For example, the large Kano Province in Northern Nigeria, a well-institutionalized precolonial emirate with 2.3 million inhabitants, was ruled by only fourteen British administrators in 1927. In comparison, Ogoja's .6 million inhabitants in the acephalous southeastern part of the colony were governed by twenty-one administrators. A simple linear model yields a very similar association (Appendix A3.4, Table A21). An increase in the political centralization of a province/district by one level is associated with a decrease of about three British administrators per million inhabitants $(p<.05)$. While adding only the vector of ethnic co-variates does not change this result, adding the vector of eight "nature" controls decreases the size of the coefficient and turns it insignificant. Although this is reason for concern, this might well be a result of the very small sample size. None of the additional covariates is associated with a statistically significant effect or increases the fit of the model. I take these results as corroborating the earlier finding that strong precolonial institutions facilitated British indirect rule and allowed them to exert less administrative effort.

\section{Evidence on the Devolution of Power}

After highlighting the negative relationship between precolonial centralization and local administrative effort by British but not French colonial governments, the next set of analyses focuses on the second facet of indirect rule: the power of indigenous authorities. In line with my discussion of historical evidence, I expect that indirect British rule came with more devolution of power to local authorities where these 
could build on centralized precolonial institutions. To probe this argument, I analyze the size of native treasuries budgets in four British colonies as well as data on local administrative finances in French West Africa from Huillery ${ }^{118}$ and the status of chiefs in Nigeria. I expect centralized areas to feature larger budgets and more powerful chiefs, both taken as proxies for indirect rule.

Native treasuries' budgets. I estimate the effect of precolonial centralization on the revenues and expenditures of native treasuries under British rule in a crosssectional manner. Because the previous analysis suggests that large districts are a consequence of precolonial centralization, the following considers the absolute and per capita size of native treasuries separately. The first set of regressions includes the full set of controls and takes absolute budget values as outcomes. The second set uses per capita budget values as outcomes and additionally controls for districts' logged population and size.

In line with the expectation of greater powers devolved to indirectly ruled precolonial states, they are associated with much larger native treasuries, in absolute and per capita terms. An increase in the precolonial level of political hierarchy by one level - moving from an acephalous society to petty chiefdoms, or from a large chiefdom to a state - is associated with an increase of total budgets by between 65 and 73 percent and of per capita revenues and expenditures by around 28 percent (Table 6). ${ }^{119}$ The respective coefficients are precisely estimated and consistent across the revenue and expenditure sides of local budgets. ${ }^{120}$ The results show that native authorities in British colonies presided over larger, more powerful, and more

\footnotetext{
${ }^{118}$ Huillery 2010.

${ }^{119}$ Again, because of the logged outcomes, I calculate these percentage changes as $(\exp (\beta)-1) * 100$.

${ }^{120}$ They are also closely in line with estimates reported by Bolt and Gardner 2018.
} 
effective local governments where they could rule indirectly through pre-existing, centralized institutions.

Table 6: Native treasuries under British rule: per-capita revenues and expenditures (logged 2016 $£)$

\begin{tabular}{|c|c|c|c|c|}
\hline & \multicolumn{2}{|c|}{ Revenues } & \multicolumn{2}{|c|}{ Expenditures } \\
\hline & $\begin{array}{l}\text { total } \\
(1)\end{array}$ & $\begin{array}{c}\text { per capita } \\
(2)\end{array}$ & $\begin{array}{c}\text { total } \\
(3)\end{array}$ & $\begin{array}{c}\text { per capita } \\
(4)\end{array}$ \\
\hline Precol. centralization & $\begin{array}{l}0.503^{* * *} \\
(0.125)\end{array}$ & $\begin{array}{l}0.242^{* * *} \\
(0.078)\end{array}$ & $\begin{array}{l}0.546^{* * *} \\
(0.127)\end{array}$ & $\begin{array}{l}0.257^{* * *} \\
(0.088)\end{array}$ \\
\hline Pop. density 1880 (log) & $\begin{array}{c}0.246 \\
(0.178)\end{array}$ & $\begin{array}{c}-1.958^{* * *} \\
(0.469)\end{array}$ & $\begin{array}{c}0.202 \\
(0.242)\end{array}$ & $\begin{array}{c}-2.009^{* * *} \\
(0.665)\end{array}$ \\
\hline Ethnic pop. density $1880(\log )$ & $\begin{array}{c}0.357 \\
(0.305)\end{array}$ & $\begin{array}{c}0.494^{* *} \\
(0.205)\end{array}$ & $\begin{array}{c}0.493 \\
(0.379)\end{array}$ & $\begin{array}{c}0.594^{* *} \\
(0.257)\end{array}$ \\
\hline Distance to coast (log) & $\begin{array}{c}0.053 \\
(0.105)\end{array}$ & $\begin{array}{r}-0.139^{*} \\
(0.077)\end{array}$ & $\begin{array}{c}0.113 \\
(0.107)\end{array}$ & $\begin{array}{c}-0.071 \\
(0.078)\end{array}$ \\
\hline Distance to river (log) & $\begin{array}{c}0.057 \\
(0.122)\end{array}$ & $\begin{array}{r}-0.050 \\
(0.088)\end{array}$ & $\begin{array}{c}0.081 \\
(0.139)\end{array}$ & $\begin{array}{c}0.035 \\
(0.097)\end{array}$ \\
\hline Population (log) & & $\begin{array}{l}1.600^{* * *} \\
(0.402)\end{array}$ & & $\begin{array}{l}1.641^{* * *} \\
(0.597)\end{array}$ \\
\hline Area (log) & & $\begin{array}{c}-1.674^{* * *} \\
(0.423)\end{array}$ & & $\begin{array}{c}-1.672^{* * *} \\
(0.596)\end{array}$ \\
\hline Colony FE: & yes & yes & yes & yes \\
\hline Nature controls: & yes & yes & yes & yes \\
\hline Ethnic controls: & yes & yes & yes & yes \\
\hline Mean DV: & 13 & 1.1 & 14 & 1.2 \\
\hline Observations & 146 & 146 & 126 & 126 \\
\hline Adjusted $\mathrm{R}^{2}$ & 0.550 & 0.624 & 0.452 & 0.569 \\
\hline
\end{tabular}

Notes: OLS models. Standard errors are clustered on the province-level. The sample includes the colonies of the Gold Coast (Ghana), Nigeria, Nyasaland (Malawi), and Uganda. Nature controls consist of median altitude and slope, mean annual temperature, precipitation and evapotranspiration, the ratio of the two, agricultural suitability, and soils' suitability for cash crop production. Ethnic controls include the reliance on agriculture and pastoralism, as well as the intensity of agricultural activities. Significance codes: ${ }^{*} \mathrm{p}<0.1{ }^{* *} \mathrm{p}<0.05 ;{ }^{* * *} \mathrm{p}<0.01$.

I conduct a series of robustness checks, fully reported in Appendix A4.1. Following the previous analysis, I test whether the disease environment, the unequal weight of colonies, or outliers bias the results. Furthermore, I report alternative specifications of the model that do more justice to the panel character of the original 
budget data, moving from the cross-sectional analysis to a district-weighted panel and hierarchical models. The estimated association between revenues per capita and precolonial centralization remains stable in size and statistical significance. I also re-estimate the main model using the alternative measures of precolonial centralization $^{121}$ and a dummy for districts that feature a capital of a precolonial polity in 1885. Districts with a capital in 1885 exhibit larger budgets, but not on a per capita basis. Although speculatively, this might be indicative of indirect rule's differential effectiveness in rural and urban(izing) areas that developed around the old centers of society. I also disaggregate the analysis into the main revenue and expenditure lines of the budgets. The findings are prevalent across almost all budget items. Finally, a colony-level jackknife analysis reveals that the results are mainly driven by observations of Nigerian local budgets, which numerically dominate the sample (see Table 4).

To explore whether similar or opposite dynamics marked district finances in French colonies, I make use of Huillery's data on tax collection, public investments, and service provision in 109 French West African cercles. ${ }^{122}$ The results in Appendix A4.3 suggest that precolonial centralization had no significant effect on tax collections in French West Africa, but a negative effect on investments and spending on teachers and doctors. In per-capita terms, only the number of doctors is significantly lower in centralized districts than elsewhere; all other indicators yield statistically insignificant results. Although in itself not fully conclusive, these insignificant but negative associations provide a foil to compare the results from the British colonies against. This comparison increases the confidence that the posi-

\footnotetext{
${ }^{121}$ From Michalopoulos and Papaioannou 2013.

${ }^{122}$ Huillery 2010.
} 
tive association between precolonial institutions and native treasuries' resources in British colonies are indeed due to indirect rule over precolonially centralized polities.

The power of chiefs. The analysis of British native treasuries consistently shows that native administrations had more financial resources at their disposal if they were located in areas with high degrees of precolonial centralization. However, chiefs in centralized and decentralized areas might have enjoyed the same status, with the former being able to more effectively use their powers. An analysis of the highest class of chiefs in Nigerian districts shows that this doubt is unfounded (Table A28). Precolonial centralization correlates strongly with the class of chiefs. Districts in the territory of precolonial kingdoms featured many more "first class" chiefs than acephalous areas, which were most often headed by "third class" chiefs.

This pattern of greater powers remaining in the hands of chiefs who could build on precolonial institutions in Nigeria completes the picture of the second analytical part of this study. Drawing on data on districts' sizes, British administrators, native treasuries, and the power of local chiefs, the analyses provide consistent evidence that the British devolved more power to indigenous elites where centralized precolonial institutions offered readily usable structures for indirect rule. This dynamic is not apparent in data from the French colonies where, as we have seen, direct rule came with the frequent demise and downfall of precolonial polities.

\section{Conclusion}

Following up on the decades-old debate on indirect rule, in this article I have brought forward systematic empirical evidence on variation in the application of indirect rule 
between the French and the British empire and within British and French colonies in Africa. I argue that the French have ruled more directly and against rather than through precolonial institutions. In comparison, the British ideal of indirect rule and local self-government could be most effectively realized in areas that featured centralized precolonial institutions. Elsewhere, in particular in acephalous societies, the British established more direct rule to bridge the gap between the colonizers and the population.

The systematic evidence presented here supports both arguments. First, French rule was hostile toward precolonial polities to a degree that about 70 percent of all colonized polities ceased to exist before independence. In British colonies, this figure amounts to about 30 percent. Second, where strong precolonial institutions prevailed and the British ruled, districts were 35 to 54 percent larger than in areas settled by acephalous societies. They were by the same amount smaller where the French ruled. Within British colonies, equivalent differences are apparent in the size of native administrations' budgets, both in absolute and per capita terms. I interpret larger districts and budgets of local native administrations as proxies for local indirect rule. These patterns thus strongly support the argument that indirect rule was implemented where pre-existing institutions could be co-opted by the colonial state.

These results have consequences for research on the establishment of political hierarchies in comparative politics and international relations. For one, I find that indirect rule through cooptation crucially depends on the political centralization and capabilities of the polity to be subordinated. In the international realm, it may therefore come as no surprise that the United States could outsource, for example, the "war on terror" to some states, but saw the need for relatively and increasing 
direct involvement in post-2001 Afghanistan where the central government was too weak to act as a reliable proxy. ${ }^{123}$ For another, I identify differences in the indirectness of rule that can only be explained by the characteristics of the colonizing empires. This raises the expectation that different actors follow diverging strategies of dominance over subordinates, dictated by their internal power structure, ideological preferences, or limitations in their powers to coerce. This may be relevant to understand rather direct rule over the Eastern Bloc implemented by the ideologically more transformative and geographically closer USSR compared to the relation of the United States to Western Europe. ${ }^{124}$

My findings also bear important implications for understanding political development in Africa. Contrary to a deterministic view that "there is often nothing new out of Africa," 125 the evidence shows that local governance institutions were shaped by colonialism, but not in a uniform manner. The diversity of colonial experiences ${ }^{126}$ interacted with the local precolonial past in shaping colonial and postcolonial sociopolitical development. Arguments that neglect this heterogeneity by positing direct links between the (pre-)colonial past and the present might thus, in some cases, overly compress history. ${ }^{127}$

In particular, variation in indirect rule between and within colonial empires likely affects states' treatment of traditional authorities until today. What effects does colonial indirect rule have, for example, on postcolonial local governance, ${ }^{128}$ ethnic

\footnotetext{
${ }^{123}$ Katzman 2010; Monten 2014.

${ }^{124}$ See Lake 2011 on indirect US rule over Western Europe.

${ }^{125}$ Herbst 2000, 30 .

${ }^{126}$ These go of course well beyond the dimension of indirect rule, as the impacts of cash crop agriculture (Hopkins, 1973; Roessler et al., 2018) or Christianity (Lankina and Getachew, 2012) suggest.

${ }^{127}$ Austin 2008.

${ }^{128}$ Acemoglu, Reed and Robinson 2014; Lange 2009.
} 
politics and conflict, ${ }^{129}$ traditional institutions, ${ }^{130}$ and land rights? ${ }^{131}$ Since indirect rule still belongs to the repertoires of states today and chiefs act as brokers ${ }^{132}$ and auxiliaries ${ }^{133}$ of politicians and the state, better evidence on its short- and longterm effects on local and national politics is of considerable value.

Finally, in this article I show that European imperialism came with a variety of local governance arrangements, posing questions on the effects they had on the local population. What was the impact of direct and indirect rule on the lives and livelihoods of the millions colonized and ruled by either district officers, traditional rulers, or warrant chiefs? How did the style of local rule affect the level of violence, destruction, and extraction committed by the European empires and their local intermediaries? The present characterization and measurement of indirect colonial rule may offer a useful starting point for answering such questions.

\footnotetext{
${ }^{129}$ Cederman, Gleditsch and Buhaug 2013; Paine 2019; Wig 2016.

${ }^{130}$ Acemoglu et al. 2014; Baldwin 2016.

${ }^{131}$ Berry 1992; Boone 2003; Firmin-Sellers 2000; Honig 2017.

${ }^{132}$ Baldwin 2014; de Kadt and Larreguy 2018; Nathan 2019.

${ }^{133}$ Baldwin 2013; Henn 2018.
} 


\section{References}

Acemoglu, Daron, Isaías N. Chaves, Philip Osafo-Kwaako, and James A. Robinson. 2014. Indirect Rule and State Weakness in Africa: Sierra Leone in Comparative Perspective. NBER Working Paper 20092.

Acemoglu, Daron, Tristan Reed, and James A. Robinson. 2014. Chiefs: Economic Development and Elite Control of Civil Society in Sierra Leone. Journal of Political Economy $122(2): 319-68$.

Achebe, Chinua. 1958. Things Fall Apart. W. W. Norton \& Company, 1958th edn.

Afigbo, Adiele Eberechukwu. 1972. The Warrant Chiefs: Indirect Rule in Southeastern Nigeria 1891-1929. Longman.

Ali, Merima, Odd-Helge Fjeldstad, Boqian Jiang, and Abdulaziz B. Shifa. 2018. Colonial Legacy, State-building and the Salience of Ethnicity in Sub-saharan Africa. Economic Journal, forthcoming.

Asiwaju, Anthony I. 1970. The Aleketu of Ketu and the Onimek of Meko: The Changing Status of two Yoruba Rulers under French and British rule. In West African Chiefs. Their Changing Status under Colonial Rule and Independence, edited by Michael Crowder and Obaro Ikime, 134-161. University of Ife Press.

Austin, Gareth. 2008. The "Reversal of Fortune" Thesis and the Compression of History: Perspectives from African and Comparative Economic History. Journal of International Development 20:996-1027.

Baldwin, Kate. 2013. Why Vote with the Chief? Political Connections and Public Goods Provision in Zambia. American Journal of Political Science 57 (4):794-809.

Baldwin, Kate. 2014. When Politicians Cede Control of Resources: Land, Chiefs and Coalition-Building in Africa. Comparative Politics 46 (3):253-71.

Baldwin, Kate. 2016. The Paradox of Traditional Chiefs in Democratic Africa. Cambridge University Press.

Berry, Sara. 1992. Hegemony on a Shoestring: Indirect Rule and Access to Agricultural Land. Africa: Journal of the International African Institute 62 (3):327-55.

Bogdanor, Vernon. 2001. Devolution in the United Kingdom. Oxford University Press.

Bolt, Jutta, and Leigh Gardner. 2018. Tax Compliance under Indirect Rule in British Africa. AEHN Working Paper 2018 (40).

Boone, Catherine. 2003. Political Topographies of the African State. Cambridge University Press.

Breuel, Thomas. 2014. A Python-based OCR Package Using Recurrent Neural Networks. Available at https://github.com/tmbdev/ocropy .

Brownlie, Ian. 1979. African Boundaries. A Legal and Diplomatic Encyclopedia. University of California Press.

Bruhn, Miriam, and Francisco A. Gallego. 2012. Good, Bad, and Ugly Colonial Activities: Do They Matter for Economic Development? Review of Economics and Statistics 94 (2):433-61. 
Burbank, Jane, and Frederick Cooper. 2010. Empires in Worls History. Power and the Politics of Difference. Princeton University Press.

Cederman, Lars-Erik, Kristian Skrede Gleditsch, and Halvard Buhaug. 2013. Inequality, Grievances, and Civil War. Cambridge University Press.

Cogneau, Denis, and Alexander Moradi. 2014. Borders that Divide: Education and Religion in Ghana and Togo since Colonial Times. Journal of Economic History 74 (3):694-729.

Cohen, William B. 1971a. Rulers of Empire: the French Colonial Service in Africa. Hoover Institution Press.

Cohen, William B. 1971b. The French Colonial Service in West Africa. In France and Britain in Africa. Imperial Rivalry and Colonial Rule., edited by Prosser Gifford and WM. Roger Louis, 491-514. Yale University Press.

Conklin, Alice L. 1997. A Mission to Civilize. The Republican Idea of Empire in France and West Africa, 1895-1930. Stanford University Press.

Cooley, Alexander. 2005. Logics of Hierarchy: The Organization of Empires, States, and Military Occupation. Cornell University Press.

Crowder, Michael. 1968. West Africa under Colonial Rule. Hutchinson.

Crowder, Michael. 1971a. The White Chiefs of Tropical Africa. In Colonialism in Africa, 1870-1960. Volume 2., edited by Peter Duignan and L. H. Gann, 320-50. Cambridge University Press.

Crowder, Michael, ed. 1971b. West African Resistance. Hutchinson.

Crowder, Michael, and Obaro Ikime, eds. 1970. West African Chiefs. Their Changing Status under Colonial Rule and Independence. University of Ife Press.

de Kadt, Daniel, and Horacio Larreguy. 2018. Agents of the Regime? Traditional Leaders and Electoral Behavior in South Africa. Journal of Politics 80 (2):382-399.

Depetris-Chauvin, Emilio. 2014. State History and Contemporary Conflict: Evidence From Sub-Saharan Africa. Unpublished Working Paper .

Englebert, Pierre, Stacy Tarango, and Matthew Carter. 2002. Dismemberment and Suffocation: A Contribution to the Debate on African Boundaries. Comparative Political Studies 35 (10):1093-1118.

FAO. 2014. Global Administrative Unit Layers. Available from: http://data.fao.org/map?entryId=f7e7adb0-88fd-11da-a88f-000d939bc5d88tab=metadata

FAO. 2015. Global Agro-Ecological Zones: Crop Suitability Index. Dataset, available online at: http://gaez.fao.org .

Firmin-Sellers, Kathryn. 2000. Institutions, Context, and Outcomes: Explaining French and British Rule in West Africa. Comparative Politics 32 (3):253-72.

Fisher, Michael H. 1984. Indirect Rule in the British Empire: The Foundations of the Residency System in India (1764-1858). Modern Asian Studies 18 (3):393-428.

Fortes, Meyer, and Edward E. Evans-Pritchard, eds. 1940. African Political Systems. Oxford University Press, 1958th edn. 
Gennaioli, Nicola, and Ilia Rainer. 2007. The Modern Impact of Precolonial Centralization in Africa. Journal of Economic Growth 12 (3):185-234.

Gerring, John, Daniel Ziblatt, Johan van Gorp, and Julián Arévalo. 2011. An Institutional Theory of Direct and Indirect Rule. World Politics 63 (3):377-433.

Gething, Peter W., Thomas P. Van Boeckel, David L. Smith, Carlos A. Guerra, Anand P. Patil, Robert W. Snow, and Simon I. Hay. 2011. Modelling the Global Constraints of Temperature on Transmission of Plasmodium Falciparum and P. Vivax. Parasites and Vectors 4 (1):92.

Goldewijk, Kees Klein, Arthur Beusen, and Peter Janssen. 2010. Long-term Dynamic Modeling of Global Population and Built-up Area in a Spatially Explicit Way: HYDE 3.1. The Holocene 2010 (1):1-9.

Griffiths, Ieuan. 1986. The Scramble for Africa: Inherited Political Boundaries. The Geographical Journal 152 (2):204-16.

Grossman, Guy, and Janet I. Lewis. 2014. Administrative Unit Proliferation. American Political Science Review 108 (01):196-217.

Grossman, Guy, Jan H. Pierskalla, and Emma Boswell Dean. 2017. Government Fragmentation and Public Goods Provision. Journal of Politics 79 (3):823-39.

Hailey, William Malcom. 1945. An African Survey. A Study of Problems Arising in Africa South of the Sahara. Oxford University Press.

Hechter, Michael. 1975. Internal Colonialism. The Celtic Fringe in British National Development, 1536-1966. Routledge \& Kegan Paul.

Hechter, Michael. 2000. Containing Nationalism. Oxford University Press.

Henn, Sören. 2018. Complements or Substitutes: State Presence and the Power of Traditional Leaders. Unpublished Working Paper. http://soerenhenn.com/files/Henn_Chiefs.pdf

Herbst, Jeffrey. 2000. States and Power in Africa. Princeton University Press.

Hicks, Ursula K. 1961. Development from Below. Local Government and Finance in Developing Countries of the Commonwealth. Oxford University Press.

Hobson, John M, and Jason C Sharman. 2005. The Enduring Place of Hierarchy in World Politics: Tracing the Social Logics of Hierarchy and Political Change. European Journal of International Relations 11 (1):63-98.

Honig, Lauren. 2017. Selecting the State or Choosing the Chief? The Political Determinants of Smallholder Land Titling. World Development 100:94-107.

Hopkins, Anthony G. 1973. An Economic History of West Africa. Longman.

Huillery, Elise. 2009. History Matters: the Long-term Impact of Colonial Public Investments in French West Africa. American Economic Journal: Applied Economics 1 (2):176-215.

Huillery, Elise. 2010. The Impact of European Settlement within French West Africa: Did Precolonial Prosperous Areas Fall Behind? Journal of African Economies 20 (2):263-311.

Iyer, Lakshmi. 2010. Direct vs. Indirect Colonial Rule in India: Long-Term Consequences. Review of Economics and Statistics 92 (4):693-713. 
Jedwab, Remi, and Alexander Moradi. 2016. The Permanent Effects of Transportation Revolutions in Poor Countries: Evidence from Africa. Review of Economics and Statistics 98 (2):268-84.

Katzman, Kenneth. 2010. Afghanistan: Post-Taliban Governance, Security, and US Policy. Congressional Research Service.

Kirk-Greene, Anthony Hamilton Millard. 1980. The Thin White Line: The Size of the British Colonial Service in Africa. African Affairs 79 (314):25-44.

Lake, David A. 2009. Hierarchy in International Relations. Cornell University Press.

Lake, David A. 2011. The Domestic Politics of International Hierarchy: Indirect Rule in the American System. Available at SSRN 1903565 .

Lange, Matthew, James Mahoney, and Matthias vom Hau. 2006. Colonialism and Development: A Comparative Analysis of Spanish and British Colonies. American Journal of Sociology 111 (5):1412-62.

Lange, Matthew K. 2009. Lineages of Despotism and Development: British Colonialism and State Power. University of Chicago Press.

Lankina, Tomila, and Lullit Getachew. 2012. Mission or Empire, Word or Sword? The Human Capital Legacy in Postcolonial Democratic Development. American Journal of Political Science 56 (2):465-83.

Levi, Margaret. 1988. Of Rule and Revenue. University of California Press.

Lewis, Martin Deming. 1962. One Hundred Million Frenchmen: The "Assimilation" Theory in French Colonial Policy. Comparative Studies in Society and History 4 (2):129-53.

Lugard, Frederick. 1965. The Dual Mandate in British Tropical Africa. Frank Cass.

Mair, Lucy. 1977. Primitive Government. A Study of Traditional Political Systems in Eastern Africa. Scolar Press.

Mamdani, Mahmood. 1996. Citizen and Subject. Contemporary Africa and the Legacy of Late Colonialism. James Currey.

Martin, Susan M. 1988. Palm Oil and Protest. An Economic History of the Ngwa Region, South-Eastern Nigeria, 1800-1980. Cambridge University Press.

Mattern, Janice Bially, and Ayşe Zarakol. 2016. Hierarchies in world politics. International Organization 70 (3):623-54.

McCauley, John F., and Daniel N. Posner. 2015. African Borders as Sources of Natural Experiments Promise and Pitfalls. Political Science Research and Methods 3 (02):409-18.

McNamee, Lachlan. 2019. Indirect colonial rule and the salience of ethnicity. World Development 122:142-56.

Michalopoulos, Stelios, and Elias Papaioannou. 2013. Pre-Colonial Ethnic Institutions and Contemporary African Development. Econometrica 81 (1):113-52.

Miles, William F. S. 1994. Hausaland Divided. Colonialism and Independence in Nigeria and Niger. Cornell University Press. 
Monten, Jonathan. 2014. Intervention and State-building: Comparative Lessons from Japan, Iraq, and Afghanistan. The Annals of the American Academy of Political and Social Science 656 (1):173-91.

Murdock, George Peter. 1959. Africa. Its Peoples and Their Culture History. McGraw-Hill Book Company.

Murdock, George Peter. 1967. Ethnographic Atlas. University of Pittsburgh Press.

Nathan, Noah L. 2019. Electoral Consequences of Colonial Invention: Brokers, Chiefs, and Distribution in Northern Ghana. World Politics 71 (3):417-56.

Nexon, Daniel H. 2009. The Struggle for Power in Early Modern Europe. Religious Conflict, Dynastic Empires, and International Change. Princeton University Press.

Nunn, Nathan, and Leonard Wantchekon. 2011. The Slave Trade and the Origins of Mistrust in Africa. American Economic Review 101 (7):3221-52.

Paine, Jack. 2019. Ethnic Violence in Africa: Destructive Legacies of Pre-Colonial States. International Organization 73 (3):645-83.

Perham, Margery. 1937. Native Administration in Nigeria. Oxford University Press.

Programme Against African Trypanosomosis. 1999. Predicted Areas of Suitability for Tsetse Fly Groups and Species. Accessed on 2019/01/19 from: http://www.fao.org/paat/resources/atlases/tsetse-and-aat/en/ .

Ramankutty, Navin, Jonathan A Foley, John Norman, and Kevin McSweeney. 2002. The Global Distribution of Cultivable Lands: Current Patterns and Sensitivity to Possible Climate Change. Global Ecology and Biogeography 11 (5):377-92.

Ranger, Terence. 1997. The Invention of Tradition in Colonial Africa. In Perspectives on Africa: A Reader in Culture, History, and Representation, edited by Roy Richard Grinker, Stephen C. Lubkemann, and Christopher B. Steiner, 597-612. Wiley-Blackwell.

Reid, Richard J. 2002. Political Power in Pre-colonial Buganda: Economy, Society 83 Warfare in the Nineteenth Century. James Currey.

Roberts, Stephen H. 1929. The History of French Colonial Policy 1870-1925. Frank Cass, 1963rd edn.

Roessler, Philip, Yannick Pengl, Kyle Titlow, and Rob Marty. 2018. The Empty Panorama: The Colonial Origins of Spatial Inequality in Africa. Unpublished Working Paper.

Scott, James C. 2017. Against the Grain. A Deep History of the Earliest States. Yale University Press.

Skinner, Elliott P. 1970. The Changing Status of the 'Emperor of the Mossi' Under Colonial Rule and Since Independence. In West African Chiefs. Their Changing Status under Colonial Rule and Independence, edited by Michael Crowder and Obaro Ikime, 98-123. University of Ife Press.

Stewart, John. 2006. African States and Rulers. McFarland.

Suret-Canale, Jean. 1988. Essays on African History: From the Slave Trade to Neocolonialism. C. Hurst.

Tignor, Robert L. 1971. Colonial Chiefs in Chiefless Societies. The Journal of Modern African Studies 9 (3):339-59. 
Tilly, Charles, ed. 1975. The Formation of Nation States in Western Europe. Princeton University Press.

Tordoff, William. 1968. The Dismemberment and Revival of the Ashanti Confederacy. Journal of British Studies 7 (2):151-68.

United Kingdom War Office. 1929. Military Report on Nigeria. Volume I. (General). War Office.

Weber, Eugen. 1977. Peasant into Frenchmen. The Modernization of Rural France 18701914. Chatto \& Windus.

Weber, Max. 1958. The Three Types of Legitimate Rule. Publications in Society and Institutions $4(1): 1-11$.

Weiskel, Timothy C. 1980. French Colonial Rule and the Baule People: Resistance and Collaboration, 1889-1911. Clarendon Press.

Wesseling, Hendrik Lodewijk. 1996. Divide and Rule. The Partition of Africa, 1880-1914. Praeger.

Wig, Tore. 2016. Peace from the Past: Pre-colonial Political Institutions and Civil Wars in Africa. Journal of Peace Research 53 (4):509-24.

Wilks, Ivor. 1975. Asante in the Ninetheenth Century. The Structure and Evolution of Political Order. Cambridge University Press.

Wucherpfennig, Julian, Philipp M Hunziker, and Lars-Erik Cederman. 2016. Who Inherits the State? Colonial Rule and Post-Colonial Conflict. American Journal of Political Science 60 (4):882-98.

Young, Crawford. 1994. The African Colonial State in Comparative Perspective. Yale University Press. 


\title{
Supporting Information
}

\author{
Continuity or Change? \\ (In)direct Rule in British and French Colonial Africa
}

\section{Table of Contents}

A1 Data. . . . . . . . . . . . . . . . . . $\mathrm{A} 2$

A1.1 Precolonial polities . . . . . . . . . . . . . . . . . . A2

A1.2 Districts and regions in British and French colonies . . . . . . . . A10

A1.3 Data on native treasuries in British colonies . . . . . . . . . . . A12

A1.4 Correlations between indicators of British indirect rule . . . . . . A18

A2 Evidence from the survival of lines of succession . . . . . . . . . . A18

A2.1 Main robustness checks . . . . . . . . . . . . . . . . . . . . A19

A2.2 Linear models . . . . . . . . . . . . . . . . . . . . . . . . A20

A2.3 Colony-level jackknife . . . . . . . . . . . . . . . . . . . . . A22

A2.4 Survival of rulers before and after colonization . . . . . . . . . . A23

A2.5 The demise of polities in (coastal) West Africa . . . . . . . . . . A25

A3 Evidence from colonial districts . . . . . . . . . . . . . . . . . A28

A3.1 Districts' size: Robustness checks . . . . . . . . . . . . . . . . A28

A3.2 Colony-level jackknife . . . . . . . . . . . . . . . . . . . . . A30

A3.3 Districts' size across French-British borders . . . . . . . . . . . A32

A3.4 British administrators . . . . . . . . . . . . . . . . . . . A38

A4 Evidence from native administrations. . . . . . . . . . . . . . . A39

A4.1 Robustness checks . . . . . . . . . . . . . . . . . . . . . . A39

A4.2 Colony-level jackknife . . . . . . . . . . . . . . . . . . . . . A43

A4.3 French West Africa . . . . . . . . . . . . . . . . . . . . . . A44

A4.4 Chiefs' class in colonial Nigeria . . . . . . . . . . . . . . . . . A45 


\section{A1 Data}

This appendix provides an overview over the data collected for the analyses of indirect rule in British and French colonies presented in the main text. Subsection A1.1 presents the data on precolonial polities and their lines of succession digitized from the encyclopedia of 'African States and Rulers' compiled by Stewart (2006). Subsection A1.2 presents the newly collected data on districts in British and French colonies and Subsection A1.3 presents data on the budgets of native treasuries in four British colonies. Finally, Subsection A1.4 briefly summarizes the correlations between the four main proxies of indirect rule in British colonies: the size of districts, the number of British administrators, the size of native treasuries, and the class of chiefs in Nigeria.

\section{A1.1 Precolonial polities}

Table A1: Summary of data on lines of succesion

\begin{tabular}{lccccc}
\hline \hline Statistic & $\mathrm{N}$ & Mean & St. Dev. & Min & Max \\
\hline British rule & 5237 & 0.787 & 0.409 & 0 & 1 \\
French rule & 5237 & 0.213 & 0.409 & 0 & 1 \\
Year & 5237 & 1923.307 & 22.528 & 1830 & 2006 \\
Population (log) & 5208 & 3.736 & 1.498 & 0.000 & 7.769 \\
Distance to coast (log) & 5208 & 5.506 & 1.828 & 0.355 & 7.397 \\
Distance to nav. river (log) & 5208 & 4.637 & 1.451 & -0.223 & 7.724 \\
Polity age (log) & 5237 & 5.573 & 0.752 & 2.197 & 7.096 \\
Dependence on agriculture & 5016 & 1.913 & 1.376 & 0 & 8 \\
Dependence on husbandry & 5016 & 5.644 & 2.380 & 0 & 9 \\
Intensity of agriculture & 4792 & 2.096 & 0.980 & 0 & 4 \\
Precol. centralization & 4790 & 1.882 & 1.095 & 0 & 4 \\
Altitude (median) & 5208 & 500.653 & 430.092 & 5 & 1745 \\
Slope (median) & 5208 & 3.978 & 1.607 & 1 & 9 \\
Temperature (mean) & 5208 & 25.072 & 3.679 & 14.590 & 29.860 \\
Evapotranspiration & 5208 & 1732.141 & 334.175 & 1133 & 2347 \\
Precipitation & 5208 & 974.456 & 491.265 & 16 & 3006 \\
Evapotransp. / precipitation & 5208 & 3.858 & 1.337 & 1 & 7 \\
Suitability for agr. & 4902 & 0.333 & 0.210 & 0.001 & 0.785 \\
Cash crop suitability & 5208 & 0.351 & 0.162 & 0.000 & 0.863 \\
\hline
\end{tabular}

Table A1 summarizes the data on precolonial polities digitized from the encyclopedia on 'African States and Rulers' compiled by Stewart (2006) and the covariates attributed to them. The map in Figure A1 shows the spatial distribution of the polities' capitals. Table A5 at the end of this section contains the name and capital of each polity in the sample, its date of colonization by the British or the French, as well as the polity's last year in the sample, determined either by the end of its line of succession or the independence of the colony its capital is located in.

In addition to providing these summaries, this section aims to test the possibility 
that the observation of polities by Stewart (2006) is biased, in particular by potential effects of precolonial centralization and the colonizing power on the probability of observing more (or less) polities in a certain area. As throughout the paper, the analysis is limited towards polities that were colonized by either the French or the British empire. I analyze the quality of information on precolonial polities in three ways:

First, since Stewart (2006) gives a short account of the history of polities, we can systematically assess the information available for each state. For each polity that was ever colonized, I thus code the simple length of the historical account in characters. Table A2 reports the results of simple linear models of the logged number of characters on a 'British' rule dummy, the level of precolonial centralization of the (last) capital of a polity, and additional controls. The results show that Stewart does not give more detailed accounts of polities that were colonized by the British than by the French. Not surprisingly, the grand kingdoms, those polities located in highly centralized areas, are described in more detail.

The second approach is based on Murdock's (1967) ethnic settlement areas and takes the colony-ethnic polygon as the unit of analysis. For each polygon, I count

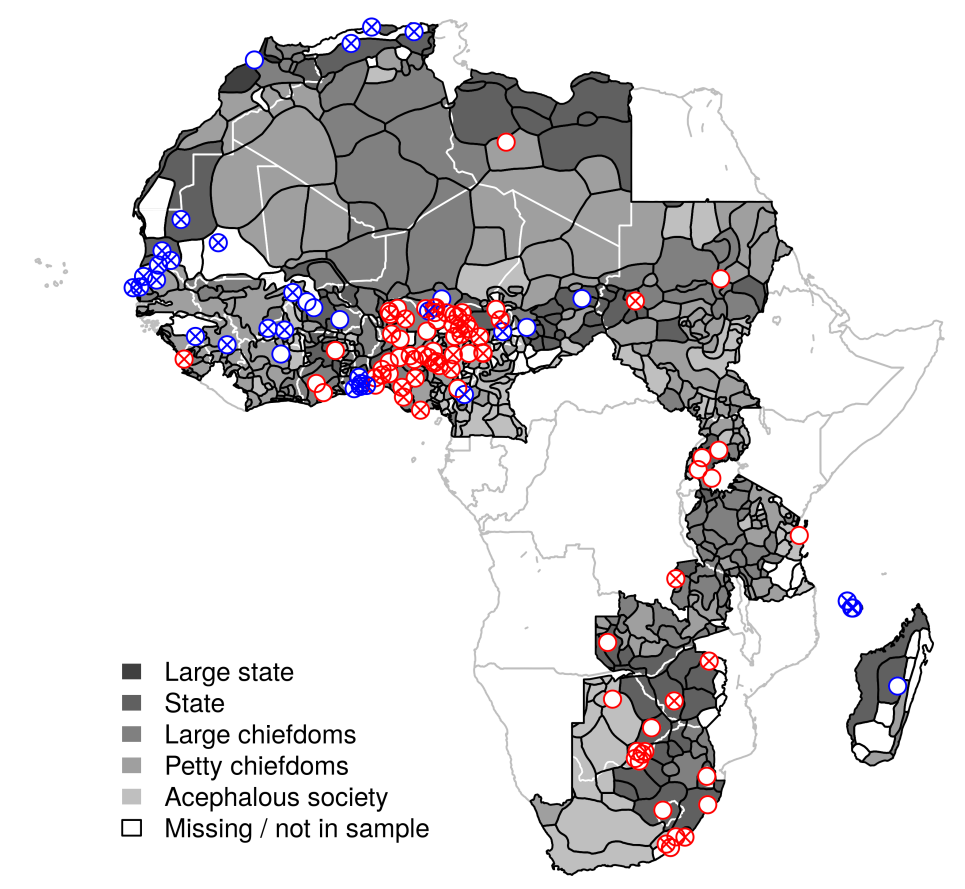

Figure A1: Polities colonized by the French or British empire in Africa.

The capitals of polities colonized by the French (British) are drawn in blue (red). Precolonial polities with lines of succession that ended before the end of the colonial period are marked with a cross. 
Table A2: Information per polity

\begin{tabular}{|c|c|c|c|}
\hline & \multicolumn{3}{|c|}{$\log ($ Characters of historical account $)$} \\
\hline & $(1)$ & $(2)$ & $(3)$ \\
\hline British colony & $\begin{array}{c}0.225 \\
(0.167)\end{array}$ & $\begin{array}{c}0.081 \\
(0.200)\end{array}$ & $\begin{array}{c}0.164 \\
(0.214)\end{array}$ \\
\hline Precol. centralization & $\begin{array}{l}0.303^{* * *} \\
(0.076)\end{array}$ & $\begin{array}{l}0.265^{* * *} \\
(0.079)\end{array}$ & $\begin{array}{c}0.255^{* *} \\
(0.099)\end{array}$ \\
\hline Population $/ \mathrm{km}^{2}(1880 ; \log )$ & $\begin{array}{c}0.037 \\
(0.047)\end{array}$ & $\begin{array}{c}0.055 \\
(0.117)\end{array}$ & $\begin{array}{c}0.020 \\
(0.120)\end{array}$ \\
\hline Distance to coast (log) & $\begin{array}{c}0.017 \\
(0.055)\end{array}$ & $\begin{array}{c}-0.013 \\
(0.064)\end{array}$ & \\
\hline Distance to river (log) & & & $\begin{array}{c}-0.026 \\
(0.070)\end{array}$ \\
\hline Nature controls: & no & yes & yes \\
\hline Ethnic controls: & no & no & yes \\
\hline Mean DV & 6.26 & 6.25 & 6.25 \\
\hline F-Stat: & 8.85 & 3.81 & 3.21 \\
\hline Observations & 104 & 100 & 100 \\
\hline Adjusted $\mathrm{R}^{2}$ & 0.276 & 0.270 & 0.263 \\
\hline
\end{tabular}

Notes: OLS models. Robust standard errors in parenthesis. Nature controls. consist of median altitude and slope, mean annual temperature, precipitation and evapotranspiration, the ratio of the two, agricultural suitability, and soils' suitability for cash crop production. Ethnic controls consist of the reliance on agriculture and pastoralism, as well as the intensity of agricultural activities. Significance codes: ${ }^{*} \mathrm{p}<0.1 ;{ }^{* *} \mathrm{p}<0.05 ;{ }^{* * *} \mathrm{p}<0.01$

the number of years that polygon has featured a polity in all year before 1885. This count comes in three flavors: the first counts every unique polity-year. The second counts every year only once, even if there are multiple polities in the same settlement area. The third adds to that a simple discount rate of 5 percent per year, so as to not overweight long-lasting empires such as Bornu in Northern Nigeria. Lastly, a simple dummy encodes whether there has ever been a polity observed by Stewart in a particular polygon.

None these four variables is significantly related to British colonization (see Table A3). Highlighting the overlap between the polity data and Murdock's Ethnographic Atlas, the degree of precolonial centralization is highly correlated with the number of years an ethnic group is associated with a precolonial polity - no matter how the latter value is constructed. For example, Model 3 suggests that moving from an acephalous ethnic group to a centralized one (precolonial centralization $=3$ ) adds 85 more 'state-years.' Figure A2 furthermore shows, that this relationship is non-linear and strongest for the highest degrees of precolonial statehood as coded by Murdock. 
Table A3: Observed polity-history per ethnic group: Difference between French and British colonizers

\begin{tabular}{|c|c|c|c|c|}
\hline & \multicolumn{4}{|c|}{ Years of precolonial data: } \\
\hline & $\mathrm{P}($ any year $)$ & discounted & unique & all \\
\hline & $(1)$ & $(2)$ & $(3)$ & $(4)$ \\
\hline British colony & $\begin{array}{c}0.019 \\
(0.024)\end{array}$ & $\begin{array}{c}3.668 \\
(3.216)\end{array}$ & $\begin{array}{c}11.697 \\
(21.714)\end{array}$ & $\begin{array}{c}24.158 \\
(37.904)\end{array}$ \\
\hline Precol. centralization & $\begin{array}{l}0.057^{* * *} \\
(0.011)\end{array}$ & $\begin{array}{l}8.734^{* * *} \\
(1.383)\end{array}$ & $\begin{array}{l}28.901^{* * *} \\
(9.339)\end{array}$ & $\begin{array}{c}32.775^{* *} \\
(16.303)\end{array}$ \\
\hline Population $/ \mathrm{km}^{2}$ (1880; log) & $\begin{array}{l}0.098^{* * *} \\
(0.012)\end{array}$ & $\begin{array}{l}12.420^{* * *} \\
(1.604)\end{array}$ & $\begin{array}{l}66.799^{* * *} \\
(10.833)\end{array}$ & $\begin{array}{l}105.719^{* * *} \\
(18.910)\end{array}$ \\
\hline Distance to coast (log) & $\begin{array}{c}0.012 \\
(0.014)\end{array}$ & $\begin{array}{c}0.347 \\
(1.829)\end{array}$ & $\begin{array}{c}14.279 \\
(12.347)\end{array}$ & $\begin{array}{c}26.332 \\
(21.554)\end{array}$ \\
\hline Distance to river $(\log )$ & $\begin{array}{c}-0.004 \\
(0.009)\end{array}$ & $\begin{array}{c}-1.238 \\
(1.193)\end{array}$ & $\begin{array}{r}-15.022^{*} \\
(8.056)\end{array}$ & $\begin{array}{r}-23.464^{*} \\
(14.063)\end{array}$ \\
\hline Area $\left(\mathrm{km}^{2}, \log \right)$ & $\begin{array}{l}0.062^{* * *} \\
(0.006)\end{array}$ & $\begin{array}{l}7.240^{* * *} \\
(0.852)\end{array}$ & $\begin{array}{l}32.662^{* * *} \\
(5.756)\end{array}$ & $\begin{array}{l}47.822^{* * *} \\
(10.049)\end{array}$ \\
\hline Ethnic controls: & yes & yes & yes & yes \\
\hline Nature controls: & yes & yes & yes & yes \\
\hline Mean DV & 0.12 & 12.98 & 47.95 & 63.87 \\
\hline F-Stat: & 13.94 & 12.5 & 7.66 & 5.94 \\
\hline Observations & 893 & 893 & 893 & 893 \\
\hline Adjusted $\mathrm{R}^{2}$ & 0.198 & 0.180 & 0.113 & 0.086 \\
\hline
\end{tabular}

Notes: OLS models. Robust standard errors in parenthesis. Nature controls consist of median. altitude and slope, mean annual temperature, precipitation and evapotranspiration, the ratio of the two, agricultural suitability, and soils' suitability for cash crop production. Ethnic controls consist of the reliance on agriculture and pastoralism, as well as the intensity of agricultural activities. Significance codes: ${ }^{*} \mathrm{p}<0.1 ;{ }^{* *} \mathrm{p}<0.05 ;{ }^{* * *} \mathrm{p}<0.01$

This underlines the quality of the data.

The third analysis (Table A4) builds on this approach, only exchanging the ethnic polygons with a simple raster of a resolution of 0.417 by 0.417 decimal degrees. The results underline the weak relationship between British rule and information on precolonial polities provided by Stewart: none of the counts of polity-years is significantly correlated with the British rule dummy. In contrast, the pattern that the Murdock coding of precolonial centralization is a significant correlate of Stewart's polity data is also prevalent when using raster cells as the units of analysis. 
Table A4: Observed polity-history per raster cell

\begin{tabular}{|c|c|c|c|c|}
\hline & & Years of pr & ial data: & \\
\hline & $\mathrm{P}$ (any year) & discounted & unique & all \\
\hline & $(1)$ & $(2)$ & $(3)$ & $(4)$ \\
\hline British colony & $\begin{array}{c}0.003 \\
(0.003)\end{array}$ & $\begin{array}{c}0.151 \\
(0.374)\end{array}$ & $\begin{array}{r}-0.852 \\
(1.700)\end{array}$ & $\begin{array}{r}-0.438 \\
(2.009)\end{array}$ \\
\hline Precol. centralization & $\begin{array}{l}0.007^{* * *} \\
(0.002)\end{array}$ & $\begin{array}{l}0.773^{\text {*** }} \\
(0.165)\end{array}$ & $\begin{array}{c}1.793^{* *} \\
(0.752)\end{array}$ & $\begin{array}{c}1.876^{* *} \\
(0.889)\end{array}$ \\
\hline Population $/ \mathrm{km}^{2}(1880 ; \log )$ & $\begin{array}{l}0.039^{* * *} \\
(0.002)\end{array}$ & $\begin{array}{l}3.187^{* * *} \\
(0.191)\end{array}$ & $\begin{array}{l}15.335^{* * *} \\
(0.868)\end{array}$ & $\begin{array}{l}17.780^{* * *} \\
(1.025)\end{array}$ \\
\hline Distance to coast (log) & $\begin{array}{l}0.004^{* *} \\
(0.002)\end{array}$ & $\begin{array}{c}0.072 \\
(0.196)\end{array}$ & $\begin{array}{c}0.212 \\
(0.889)\end{array}$ & $\begin{array}{c}0.376 \\
(1.051)\end{array}$ \\
\hline Distance to river (log) & $\begin{array}{r}-0.001 \\
(0.001)\end{array}$ & $\begin{array}{c}0.116 \\
(0.135)\end{array}$ & $\begin{array}{c}-1.312^{* *} \\
(0.614)\end{array}$ & $\begin{array}{c}-1.729^{* *} \\
(0.725)\end{array}$ \\
\hline Ethnic controls: & yes & yes & yes & yes \\
\hline Nature controls: & yes & yes & yes & yes \\
\hline Mean DV & 0.02 & 1.41 & 5.16 & 5.62 \\
\hline F-Stat: & 50.3 & 30.07 & 30.19 & 29.07 \\
\hline Observations & 9,692 & 9,692 & 9,692 & 9,692 \\
\hline Adjusted $\mathrm{R}^{2}$ & 0.075 & 0.046 & 0.046 & 0.044 \\
\hline
\end{tabular}

Notes: OLS models. Robust standard errors in parenthesis. Nature controls consist of median. altitude and slope, mean annual temperature, precipitation and evapotranspiration, the ratio of the two, agricultural suitability, and soils' suitability for cash crop production. Ethnic controls consist of the reliance on agriculture and pastoralism, as well as the intensity of agricultural activities. Significance codes: ${ }^{*} \mathrm{p}<0.1 ;{ }^{* *} \mathrm{p}<0.05 ;{ }^{* * *} \mathrm{p}<0.01$

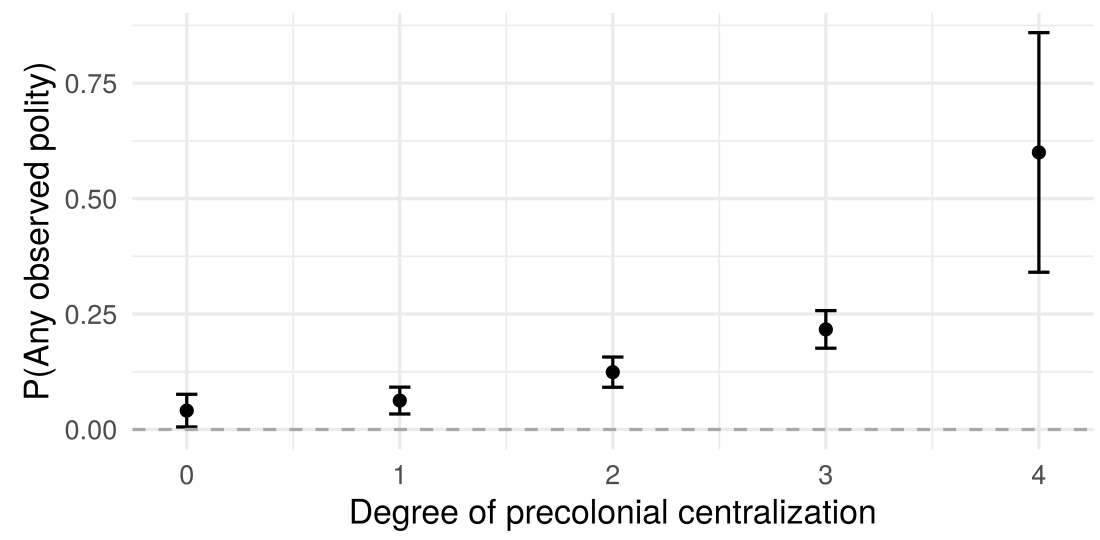

Figure A2: Probability of an ethnic group featuring a precolonial state as coded by Stewart (2006) by level of precolonial centralization. 
Table A5: Polities colonized by France or Great Britain

\begin{tabular}{|c|c|c|c|c|}
\hline Polity & Capital & Colonizer & Colonized in & End year \\
\hline Abeokuta & Abeokuta & Great Britain & 1893 & 1960 (I) \\
\hline Abuja & Abuja & Great Britain & 1902 & 1960 (I) \\
\hline Adamawa & Yola & Great Britain & 1901 & $1953(\mathrm{E})$ \\
\hline Adrar & Atar & France & 1909 & $1932(\mathrm{E})$ \\
\hline Agaie & Agaie & Great Britain & 1908 & $1953(\mathrm{E})$ \\
\hline Akim & Nsauoen & Great Britain & 1899 & $1957(\mathrm{I})$ \\
\hline Algiers & Algiers & France & 1830 & $1830(\mathrm{E})$ \\
\hline Allada & Allada & France & 1894 & $1923(\mathrm{E})$ \\
\hline Andruna & Moroni [approx] & France & 1852 & $1852(\mathrm{E})$ \\
\hline Anjouan & Domoni & France & 1866 & $1912(\mathrm{E})$ \\
\hline Argungu & Argungu & Great Britain & 1902 & $1960(\mathrm{I})$ \\
\hline Ashanti & Kumasi & Great Britain & 1896 & $1957(\mathrm{I})$ \\
\hline Baguirmi & Massenya & France & 1899 & $1960(\mathrm{I})$ \\
\hline Bakgatlaland & Mochudi & Great Britain & 1885 & $1963(\mathrm{E})$ \\
\hline Bakwenaland & Molepolole & Great Britain & 1885 & $1966(\mathrm{I})$ \\
\hline Bamaleteland & Gaberones & Great Britain & 1885 & $1966(\mathrm{I})$ \\
\hline Bamangwatoland & Serowe & Great Britain & 1885 & $1966(\mathrm{I})$ \\
\hline Bamoun & Bamoun & France & 1920 & $1933(\mathrm{E})$ \\
\hline Bangwaketseland & Kanye & Great Britain & 1885 & $1966(\mathrm{I})$ \\
\hline BaoI & Lambaye & France & 1877 & $1894(\mathrm{E})$ \\
\hline Barlokwaland & Gaberones & Great Britain & 1885 & $1966(\mathrm{I})$ \\
\hline Barolongland & Lobatsi & Great Britain & 1885 & $1966(\mathrm{I})$ \\
\hline Barotseland & LeaIui & Great Britain & 1891 & $1964(\mathrm{I})$ \\
\hline Batwanaland & Maun & Great Britain & 1885 & $1966(\mathrm{I})$ \\
\hline Bauchi & Bauchi & Great Britain & 1902 & $1960(\mathrm{I})$ \\
\hline Bedde & Gorgeram & Great Britain & 1902 & $1945(\mathrm{E})$ \\
\hline Benin [i] & Usama & Great Britain & 1897 & $1933(\mathrm{E})$ \\
\hline Biu & $\mathrm{Biu}$ & Great Britain & 1900 & $1959(\mathrm{E})$ \\
\hline Bonny & Bonny & Great Britain & 1885 & $1891(\mathrm{E})$ \\
\hline Bornu Empire & Yerwa & Great Britain & 1902 & $1960(\mathrm{I})$ \\
\hline Brakna & Shamama & France & 1904 & $1934(\mathrm{E})$ \\
\hline Brass & Brass town & Great Britain & 1885 & $1936(\mathrm{E})$ \\
\hline Buganda & Nabulagala & Great Britain & 1890 & $1962(\mathrm{I})$ \\
\hline Bunyoro & Mparo & Great Britain & 1896 & $1962(\mathrm{I})$ \\
\hline Constantine & Qusantina & France & 1837 & $1837(\mathrm{E})$ \\
\hline Dagomba & Yendi & Great Britain & 1896 & $1957(\mathrm{I})$ \\
\hline Dahomey & Abomey & France & 1891 & $1898(\mathrm{E})$ \\
\hline Damagaram & Zinder & France & 1899 & $1960(\mathrm{I})$ \\
\hline Darfur & aI-Fasher & Great Britain & 1916 & $1916(\mathrm{E})$ \\
\hline Daura & Daura & Great Britain & 1903 & $1906(\mathrm{E})$ \\
\hline Daura-Baure & Baure & France & 1903 & $1903(\mathrm{E})$ \\
\hline Daura-Zango & Zango & Great Britain & 1903 & 1960 (I) \\
\hline
\end{tabular}




\begin{tabular}{|c|c|c|c|c|}
\hline Doma & Doma & Great Britain & 1901 & $1930(\mathrm{E})$ \\
\hline Dyolof & Linger & France & 1889 & $1900(\mathrm{E})$ \\
\hline Fezzan & Sahha & Great Britain & 1943 & 1951 (I) \\
\hline Fika & Fika & Great Britain & 1899 & $1960(\mathrm{I})$ \\
\hline Fingoland & Nqamakwe & Great Britain & 1879 & $1879(\mathrm{E})$ \\
\hline Fulani Empire & Sokoto & Great Britain & 1903 & $1960(\mathrm{I})$ \\
\hline Fura Toro & Podor & France & 1877 & $1891(\mathrm{E})$ \\
\hline Futa Jallon & Timbo & France & 1881 & $1912(\mathrm{E})$ \\
\hline Gobir & Alkalawa & Great Britain & 1900 & $1960(\mathrm{I})$ \\
\hline Gombe & Gombe & Great Britain & 1902 & $1936(\mathrm{E})$ \\
\hline Gran Comoro & Moroni & France & 1893 & $1909(\mathrm{E})$ \\
\hline Gumel & Gumel & Great Britain & 1903 & $1960(\mathrm{I})$ \\
\hline Gurma & Fada N'Gurma & France & 1895 & $1960(\mathrm{I})$ \\
\hline Gwandu & Gwandu & Great Britain & 1903 & $1954(\mathrm{E})$ \\
\hline Gwiriko & $\begin{array}{l}\text { Bobo-Dioulasso } \\
\text { [approx] }\end{array}$ & France & 1890 & $1915(\mathrm{E})$ \\
\hline Hadejia & Hadejia & Great Britain & 1903 & $1960(\mathrm{I})$ \\
\hline Ibadan & Ibadan & Great Britain & 1893 & $1893(\mathrm{E})$ \\
\hline Ife & Ife & Great Britain & 1900 & $1960(\mathrm{I})$ \\
\hline Igala & Idah & Great Britain & 1901 & $1956(\mathrm{E})$ \\
\hline Ilorin & Ilorin & Great Britain & 1897 & $1960(\mathrm{I})$ \\
\hline Jema'a & Kafanchan & Great Britain & 1902 & $1960(\mathrm{I})$ \\
\hline Jemaari & Jemaari & Great Britain & 1903 & $1960(\mathrm{I})$ \\
\hline Kano & Kano & Great Britain & 1903 & $1960(\mathrm{I})$ \\
\hline Karagwe & Bukoba & Great Britain & 1920 & 1961 (I) \\
\hline Katagum & Azare & Great Britain & 1903 & $1947(\mathrm{E})$ \\
\hline Katsina & Katsina & Great Britain & 1903 & $1960(\mathrm{I})$ \\
\hline Kayor & Mbul & France & 1885 & $1886(\mathrm{E})$ \\
\hline Kazaure & Kazaure & Great Britain & 1906 & $1960(\mathrm{I})$ \\
\hline Kazembe & Kazembe & Great Britain & 1899 & $1899(\mathrm{E})$ \\
\hline Keana & [unknown] & Great Britain & 1900 & $1900(\mathrm{E})$ \\
\hline Keffi & Keffi & Great Britain & 1902 & $1948(\mathrm{E})$ \\
\hline Kenedugu & Sikasso & France & 1898 & $1898(\mathrm{E})$ \\
\hline Kom & Laikom & Great Britain & 1920 & $1960(\mathrm{I})$ \\
\hline Kong & Kong & France & 1893 & $1960(\mathrm{I})$ \\
\hline Kontagora & Kontagora & Great Britain & 1901 & $1960(\mathrm{I})$ \\
\hline Kororofa & Kororofa & Great Britain & 1901 & $1927(\mathrm{E})$ \\
\hline Koya-Temne & Robanna & Great Britain & 1896 & $1899(\mathrm{E})$ \\
\hline Kreli's Country & Kenrani & Great Britain & 1881 & $1910(\mathrm{I})$ \\
\hline Lafia & Lafia & Great Britain & 1900 & $1960(\mathrm{I})$ \\
\hline Lafiagi & Lafiagi & Great Britain & 1900 & $1960(\mathrm{I})$ \\
\hline Lagos & Lagos & Great Britain & 1861 & 1960 (I) \\
\hline Lapai & Badeggi-Lapai & Great Britain & 1900 & 1960 (I) \\
\hline Lesotho & Maseru & Great Britain & 1868 & $1966(\mathrm{I})$ \\
\hline
\end{tabular}




\begin{tabular}{|c|c|c|c|c|}
\hline Little Popo & Little Popo & France & 1920 & $1955(\mathrm{E})$ \\
\hline Madagascar & Antananarivo & France & 1885 & $1960(\mathrm{I})$ \\
\hline Mandara & Mora & France & 1920 & $1942(\mathrm{E})$ \\
\hline Mascara & Tiaret & France & 1847 & $1847(\mathrm{E})$ \\
\hline Matabeleland & Bulawayo & Great Britain & 1894 & $1894(\mathrm{E})$ \\
\hline Mayotte & Chingoni & France & 1841 & $1841(\mathrm{E})$ \\
\hline Misau & Misau & Great Britain & 1903 & $1926(\mathrm{E})$ \\
\hline Moheli & Fomboni & France & 1886 & $1912(\mathrm{E})$ \\
\hline Morocco & Rabat & France & 1907 & $1666(\mathrm{I})$ \\
\hline Muri & Jalingo & Great Britain & 1901 & $1960(\mathrm{I})$ \\
\hline Mutapa & Mount Fura & Great Britain & 1888 & $1917(\mathrm{E})$ \\
\hline \multicolumn{5}{|l|}{ Empire } \\
\hline New Calabar & Elem Kalabari & Great Britain & 1885 & $1900(\mathrm{E})$ \\
\hline Nkore & Mbarara & Great Britain & 1896 & $1962(\mathrm{I})$ \\
\hline Opobo & Opobo & Great Britain & 1884 & $1884(\mathrm{E})$ \\
\hline Оуо & New Oyo & Great Britain & 1900 & $1960(\mathrm{I})$ \\
\hline Pondoland & Port St Johns & Great Britain & 1844 & $1867(\mathrm{E})$ \\
\hline Porto-Novo & Porto-Novo & France & 1863 & $1941(\mathrm{E})$ \\
\hline Potiskum & Potiskum & Great Britain & 1901 & $1915(\mathrm{E})$ \\
\hline Rabih's Empire & Dikwa & Great Britain & 1901 & $1901(\mathrm{E})$ \\
\hline Samory's Empire & Bissandugu & France & 1898 & $1898(\mathrm{E})$ \\
\hline Sudan & Khartoum & Great Britain & 1899 & $1956(\mathrm{I})$ \\
\hline Swaziland & Mbabane & Great Britain & 1893 & $1968(\mathrm{I})$ \\
\hline Tagant & Tagant & France & 1905 & $1918(\mathrm{E})$ \\
\hline Tembuland & Umtata & Great Britain & 1885 & $1910(\mathrm{I})$ \\
\hline Trarza & Saint Louis , Trarza & France & 1902 & $1932(\mathrm{E})$ \\
\hline Tukolor Empire & Bandiagara & France & 1891 & $1891(\mathrm{E})$ \\
\hline Wadai & Abeche & France & 1909 & $1960(\mathrm{I})$ \\
\hline Wagadugu & Dazuli & France & 1897 & $1960(\mathrm{I})$ \\
\hline Walo & [unknown] & France & 1855 & $1855(\mathrm{E})$ \\
\hline Wani & Ward & Great Britain & 1884 & $1936(\mathrm{E})$ \\
\hline Wase & Wase & Great Britain & 1898 & $1948(\mathrm{E})$ \\
\hline Whydah & Savio & France & 1892 & $1898(\mathrm{E})$ \\
\hline Yatenga & Ouahigouya & France & 1895 & $1960(\mathrm{I})$ \\
\hline Yauri & Yelwa & Great Britain & 1901 & $1955(\mathrm{E})$ \\
\hline Zamfara & Anka & Great Britain & 1902 & $1946(\mathrm{E})$ \\
\hline Zanzibar & Zanzibar-City & Great Britain & 1862 & 1961 (I) \\
\hline Zaria & Zaria & Great Britain & 1902 & $1960(\mathrm{I})$ \\
\hline Zululand & Eshowe & Great Britain & 1879 & $1910(\mathrm{I})$ \\
\hline
\end{tabular}

Notes: Colonizing powers and dates only refer to colonization by France and Great Britain. The last column refers to the last year of a polity in the sample. (E) refers to the end of a line of succession during the colonial period. (I) refers to the independence of the colony whithin which a polity's capital is located. 


\section{A1.2 Districts and regions in British and French colonies}

Table A6: Summary of sources of district maps

\begin{tabular}{cccc}
\hline \hline colony & Observations & year & source \\
\hline Côte d'Ivoire & 19 & 1925 & Huillery (2009) \\
Dahomey & 13 & 1960 s & Central Intelligence Agency \\
Gold Coast & 35 & 1927 & British War Office \\
Guinée & 18 & 1925 & Huillery (2009) \\
Haute Volta & 11 & 1925 & Huillery (2009) \\
Kenya & 34 & 1962 & George Philip and Son \\
Mauretanie & 9 & 1925 & Huillery (2009) \\
Niger & 10 & 1925 & Huillery (2009) \\
Nigeria & 96 & 1962 & Central Intelligence Agency \\
Northern Rhodesia & 22 & 1948 & British War Office \\
Nyasaland & 21 & 1936 & Annual Report \\
Senegal & 14 & 1925 & Huillery (2009) \\
Sierra Leone & 13 & 1932 & British War Office \\
Soudan & 20 & 1925 & Huillery (2009) \\
Tanganyika & 58 & 1962 & George Philip and Son \\
Uganda & 15 & 1957 & Annual Departmental Reports \\
\hline
\end{tabular}

Table A6 enlists the sources for the district maps used in all analyses.

Please note that I have only been able to locate precise and labeled maps on the district-boundaries in Nigeria, Kenya, and Tanganyika for the year 1962, that is shortly after these countries' independence. It seems however unlikely that the results of the analysis are purely driven by quick territorial reforms directly after independence, in particular also because the names of districts can be matched with those of local colonial administrations without problems (see below). To digitize the available maps, I use current districts obtained form the FAO (2014) GAUL Database. Since the number of districts has sharply increased over the past 60 years, I can use current units and align them to the units observed in the past, recoding boundaries only when they significantly deviate from a modern boundary. This facilitates the tracing of boundaries over time and makes up for some lack of detail in the colonial maps. Districts are then clustered into regions, according to the historical map material. To each district and region, I then attribute a capital by recurring to a number of sources, first the maps from the colonial period, the statoids.org data base, and where the two sources do not provide the name of district or regional capitals, a Google search. The names of capitals are then geocoded trough the geonames.org gazetteer. Table A7 provides the summary statistics of the district-size data, and Figures A3 and A4 map all district boundaries used for the analysis. 


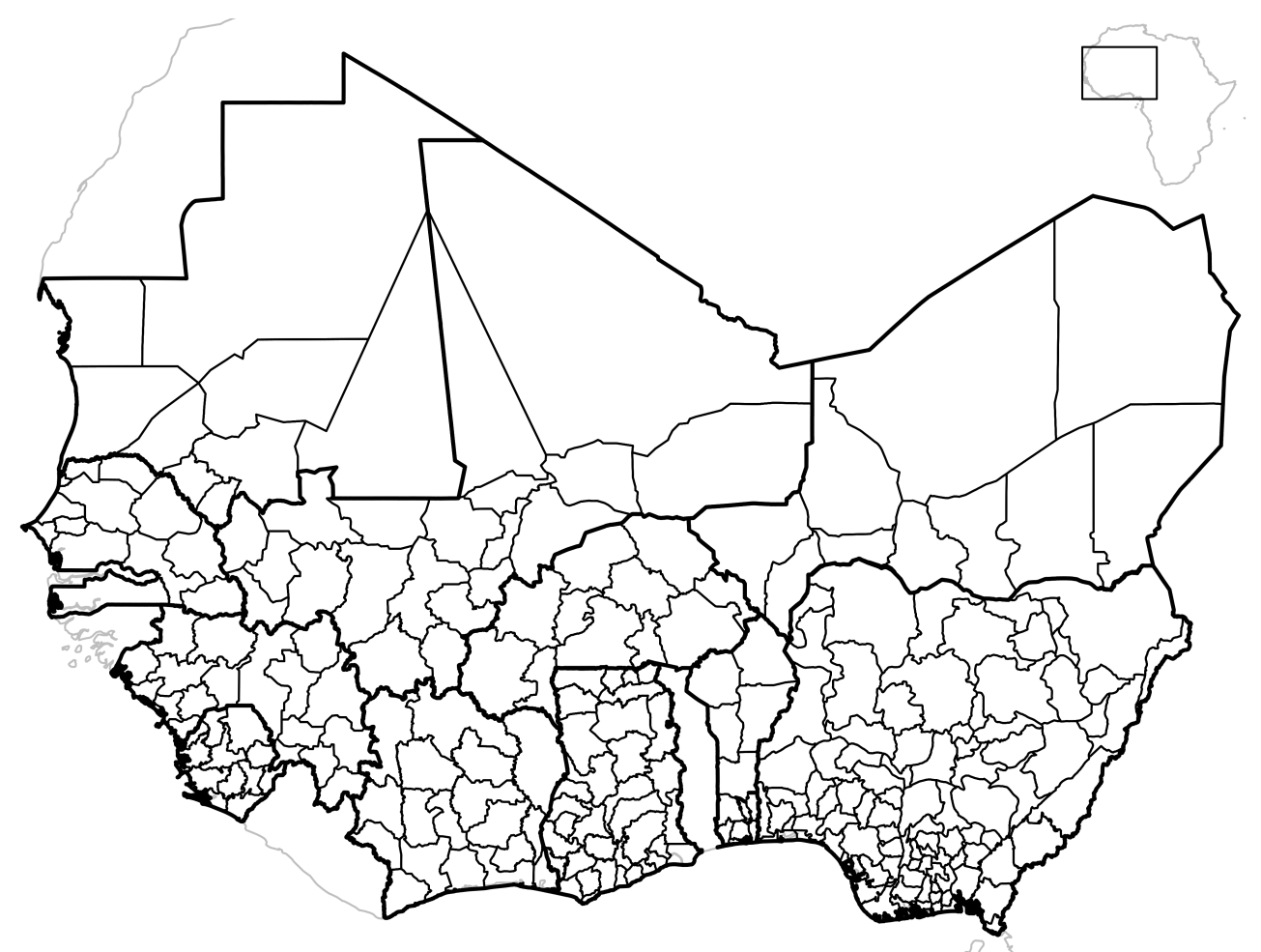

Figure A3: Districts in West Africa.

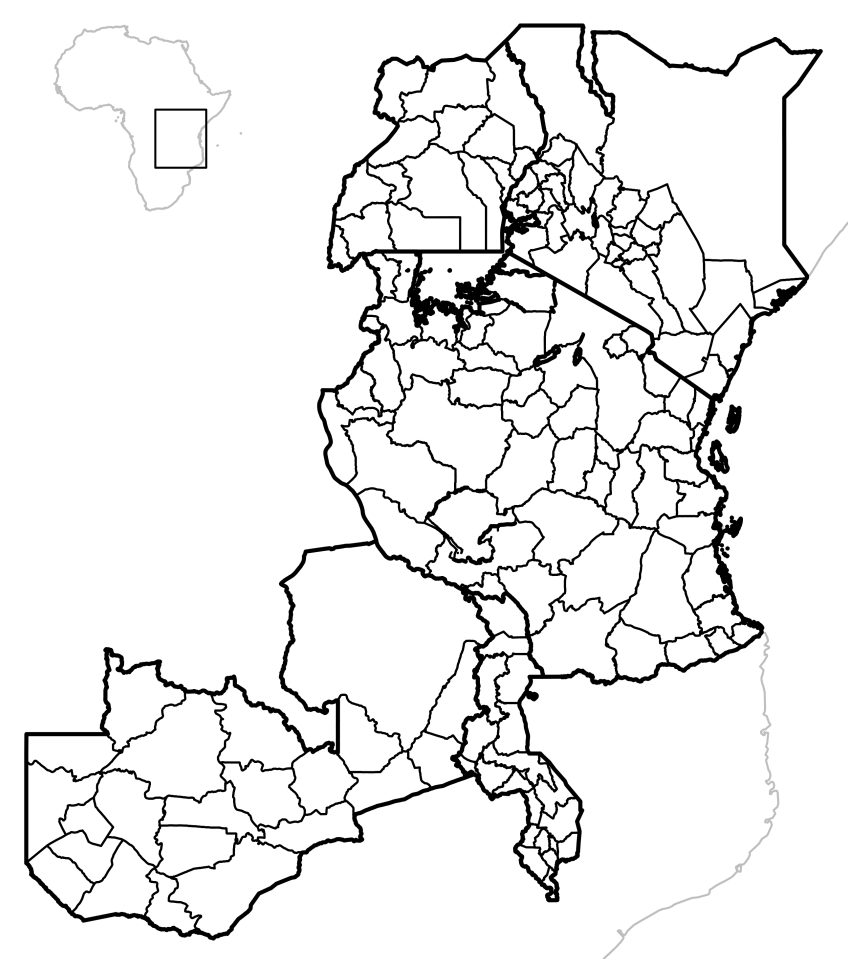

Figure A4: Districts in Southern and East Africa. 
Table A7: Summary of district-area data

\begin{tabular}{lccccc}
\hline \hline Statistic & $\mathrm{N}$ & Mean & St. Dev. & Min & Max \\
\hline French & 408 & 0.279 & 0.449 & 0 & 1 \\
Area & 408 & 20533.900 & 47162.950 & 42.942 & 520937.400 \\
Precolonial centralization & 405 & 1.521 & 0.772 & 0.000 & 3.000 \\
Population density (log) & 408 & 1.980 & 1.619 & -5.029 & 7.475 \\
Ethnic groups' population density $(\log )$ & 406 & 1.973 & 1.449 & -2.958 & 5.970 \\
Distance to coast & 408 & 4.190 & 3.155 & -2.303 & 7.021 \\
Distance to nav. river & 407 & 4.824 & 0.962 & 2.394 & 6.748 \\
Median altitude & 408 & 529.020 & 526.416 & 3.000 & 2256.611 \\
Median slope & 408 & 3.815 & 1.160 & 1.000 & 9.000 \\
Evapotranspiration & 408 & 25.184 & 3.068 & 14.504 & 29.920 \\
Precipitation & 408 & 1652.711 & 253.904 & 1195.292 & 2414.136 \\
Evapotranspiration/Precipitation & 408 & 1258.852 & 598.442 & 56.293 & 3187.805 \\
Mean temperature & 408 & 4.535 & 1.462 & 1.000 & 8.000 \\
Agricultural suitability & 403 & 0.414 & 0.213 & 0.000 & 0.938 \\
Cash crop suitability & 407 & 0.371 & 0.130 & 0.000 & 0.721 \\
Reliance on agriculture & 406 & 2.012 & 1.509 & 0.000 & 8.507 \\
Reliance on pastoralism & 406 & 6.055 & 1.460 & 0.200 & 9.000 \\
Intensity of agriculture & 405 & 2.245 & 0.561 & 0.000 & 4.000 \\
\hline
\end{tabular}

\section{A1.3 Data on native treasuries in British colonies}

The digitization of reports on native treasuries' budgets proceeds in two stages. I first process the scanned images of the respective pages in the colonial reports automatically to extract structured data from the tables they enclose. I then postprocess the results to correct errors. Subsection A1.3.1 provides details on this procedure, and Subsection A1.3.2 enlists the sources and provides an overview over the resulting data set.

\section{A1.3.1 Digitizing tables from British colonial reports}

I automatically extract structured information from tables in the scanned pages of the British Blue Books and Annual Departmental reports, information which is cleaned by hand in a second step. To this end, I developed an algorithm that transforms an image of a printed table ${ }^{134}$ into a machine readable matrix of strings which is then stored in a relational database. The algorithm proceeds as follows:

1. Image pre-processing: Transforming the images into binary black and white pixels and turning to maximize the horizontal alignment of rows. ${ }^{135}$

2. Table cell detection: Segmenting the image into rows and columns based on (1) vertical lines that delimit columns, and (2) clustering of the $\mathrm{x}$ - and $\mathrm{y}$ -

\footnotetext{
${ }^{134}$ It must be born in mind that conventional OCR programs fail at digitizing table from such deprecated scans as dealt with in the context of historical archives.

${ }^{135}$ Doing so is achieved by maximizing the standard deviation of the row-wise sum of black pixels in the image.
} 
coordinates of connected image components retrieved by a horizontal blurring filter that produces probable text blocks. Warps in the image that stem from the physical wave of the pages of an open book are corrected by using horizontal (waved) lines as reverence lines to straighten the entire image.

3. Optical character recognition (OCR): Extracting text from the cell-images using the open source program Ocropy (Breuel, 2014). Ocropy is based on a recurrent neural network which is trained on 8000 cell images from the colonial Blue Books.

Although the automatic extraction of information from the scanned image is efficient, and the OCR attains an error rate of only about $3 \%$, each page is postprocessed by hand to correct remaining inaccuracies. Such errors are highly clustered, since they mostly stem from low-quality printing and scanning on certain pages or regions of a page. Where I extract numbers, such errors are in particular worrying, since they oftentimes introduce errors in the number of digits, thus altering a number's order of magnitude. Errors also emerge if pages are printed in a font for which the neural network used for the OCR is not trained.

\section{A1.3.2 Budget data: sources and resulting data set}

Table A9 enlists all Annual Colonial Reports from which I digitize financial information on the budgets of native administrations, with Figure A5 showing an exemplary report page. Table A9 provides the summary statistics of the digitized data, averaged by district and over all years in which a district is observed. Figure A6 provides and overview over the development of per-capita revenues of the native treasuries in each district in the sample. As apparent in the plots, most districts developed very much in parallel without much variance in their rank. This strengthens the validity of the approach of using the average revenue and expenditure within a district as the main dependent variable in the respective analysis. Lastly, Figure A7 maps the average revenue by district in each colony in the sample. 
Table A8: Sources of native treasury data

\begin{tabular}{|c|c|c|c|}
\hline Colony & Title & Pages & Microform ID \\
\hline Gold Coast & Local Government Revenue and Expenditure, 1948-1951 & $\begin{array}{l}6 ; 7 ; 11 ; 14 ; 15 ; \\
35 ; 36 ; 41 ; 42 ; 45 ; \\
46 ; 71 ; 73 ; 77 ; 78 ; \\
82 ; 83\end{array}$ & $73211 \mathrm{~B}-13$ \\
\hline Nigeria & Native Authority Estimates, North, 1929-1937 & $150 ; 160 ; 301 ; 302$ & $73242 \mathrm{~B}-22$ \\
\hline Nigeria & Native Authority Estimates, North, 1934-1938 & $4 ; 147 ; 290 ; 435$ & $73242 \mathrm{~B}-23$ \\
\hline Nigeria & Native Authority Estimates, North, 1938-1941 & $4 ; 266 ; 267$ & $73242 \mathrm{~B}-24$ \\
\hline Nigeria & Native Authority Estimates, North, 1944-1946 & $135 ; 136 ; 425 ; 426$ & $73242 \mathrm{~B}-25$ \\
\hline Nigeria & Native Authority Estimates, North, 1948-1950 & $345 ; 346 ; 675 ; 676$ & $73242 \mathrm{~B}-26$ \\
\hline Nigeria & Native Authority Estimates, North, 1950-1952 & $334 ; 335 ; 336 ; 337 ; 340$ & $73242 \mathrm{~B}-27$ \\
\hline Nigeria & Memoranda on Estimates, North, 1948-1960 & $\begin{array}{l}43 ; 61 ; 80 ; 98 ; 113 ; \\
114 ; 115 ; 136 ; 156\end{array}$ & $73242 \mathrm{~B}-35$ \\
\hline Nigeria & Native Financial Statements, South, 1929-1937 & $\begin{array}{l}98 ; 192 ; 193 ; 298 ; 299 \\
416 ; 417 ; 556 ; 557\end{array}$ & $73242 \mathrm{~B}-36$ \\
\hline Nigeria & Native Financial Statements, South, 1937-1939 & $143 ; 144 ; 342$ & $73242 \mathrm{~B}-37$ \\
\hline Nigeria & Native Financial Statements, East, 1939-1943 & $157 ; 158$ & $73242 \mathrm{~B}-38$ \\
\hline Nigeria & Native Financial Statements, West, 1939-1940 & $81 ; 82$ & $73242 \mathrm{~B}-40$ \\
\hline Nyasaland & Native Affairs and Administration 1931-1945 & $\begin{array}{l}214 ; 301 ; 334 ; 378 ; 414 \\
445 ; 484 ; 518 ; 548 ; 575 \\
613 ; 624 ; 637\end{array}$ & $73105 \mathrm{~A}-01$ \\
\hline Nyasaland & Native affairs and Administration 1946-1959 & $\begin{array}{l}14 ; 31 ; 44 ; 61 ; 75 ; \\
91 ; 101 ; 114 ; 132 ; 150 ; \\
166 ; 189 ; 209 ; 225 ; 243 \\
262 ; 274 ; 285 ; 299 ; 309 \\
320 ; 335 ; 348 ; 360 ; 379 \\
391 ; 402 ; 417 ; 428 ; 441\end{array}$ & $73105 \mathrm{~A}-02$ \\
\hline Uganda & Provincial Commissioners, 1935-1938 & $\begin{array}{l}7 ; 9 ; 10 ; 11 ; 12 ; \\
17 ; 18 ; 19 ; 20 ; 21 ; \\
22 ; 23 ; 24 ; 25 ; 26 ; \\
27 ; 28 ; 36 ; 55 ; 56 ; \\
57 ; 58 ; 59 ; 70 ; 71 ; \\
72 ; 73 ; 74 ; 75 ; 85 ; \\
98 ; 100 ; 101 ; 102 ; 103 ; \\
104 ; 116 ; 119 ; 120 ; 121 ; \\
133 ; 155 ; 157 ; 158 ; 159 ; \\
160 ; 161 ; 162 ; 173 ; 174 ; \\
185\end{array}$ & 73143A-01 \\
\hline Uganda & Provincial Commissioners, 1939-1946 & $\begin{array}{l}30 ; 33 ; 34 ; 57 ; 58 ; \\
59 ; 60 ; 61 ; 62 ; 119 \\
120 ; 122\end{array}$ & 73143A-02 \\
\hline Uganda & Provincial Commissioners, 1947-1952 & $\begin{array}{l}63 ; 97 ; 98 ; 116 ; 117 ; \\
142 ; 143 ; 181 ; 216 ; 233 \\
255 ; 256 ; 305 ; 368 ; 401 \\
453 ; 454 ; 487 ; 488 ; 511 ; \\
556 ; 557 ; 615 ; 616 ; 644 ; \\
676 ; 677 ; 715 ; 716 ; 762 \\
763 ; 804 ; 864\end{array}$ & 73143A-03 \\
\hline Uganda & Provincial Commissioners, 1953-1956 & $\begin{array}{l}58 ; 59 ; 105 ; 106 ; 170 ; \\
223 ; 224 ; 270 ; 271 ; 316 ; \\
380 ; 433 ; 434 ; 484 ; 517 ; \\
518 ; 575 ; 576 ; 632 ; 696 \\
697\end{array}$ & 73143A-04 \\
\hline
\end{tabular}

Microform ID denotes the 'Reference ID' used on ww.britishonlinearchives.co.uk. 


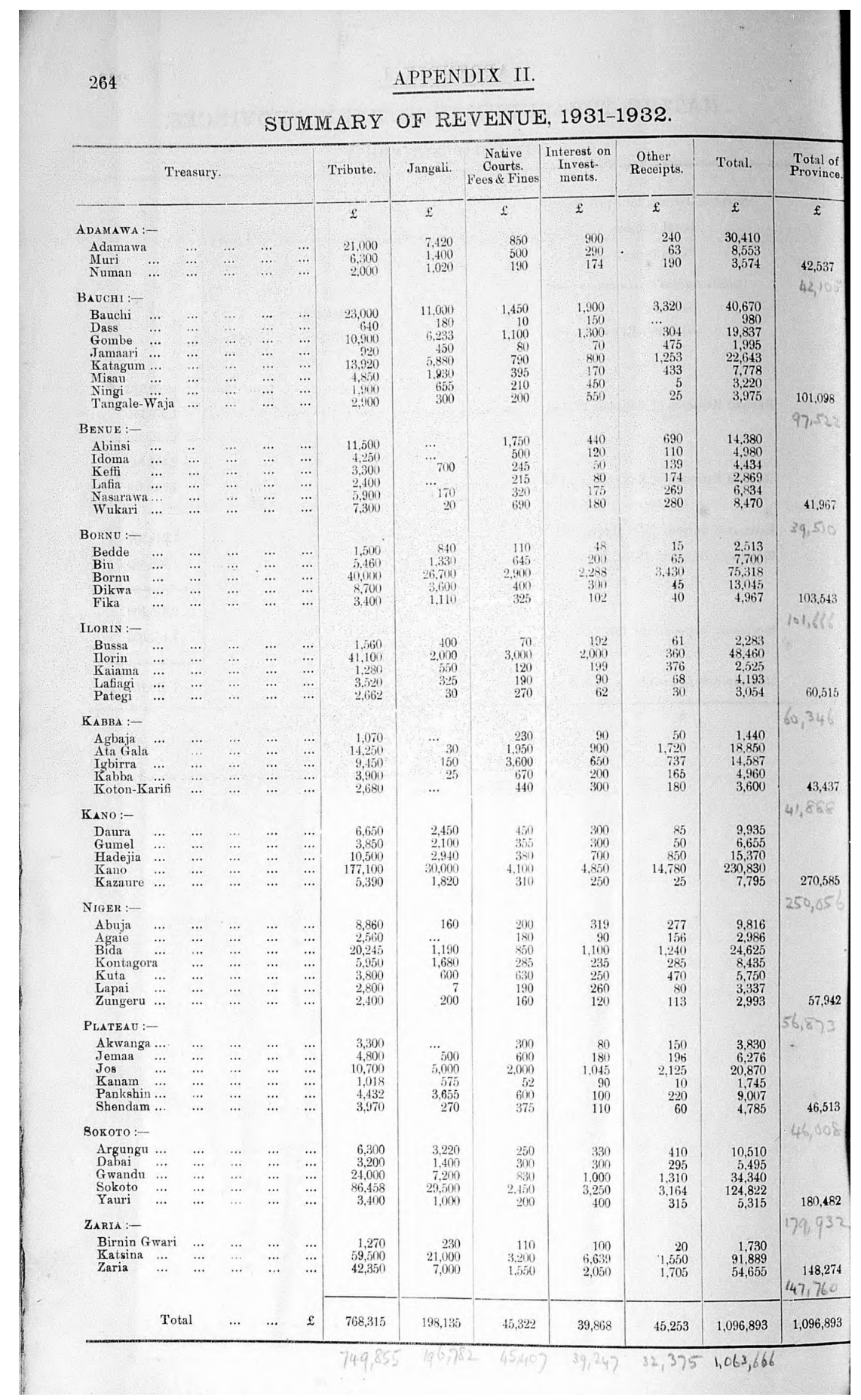

Figure A5: Detail of native treasuries' summary of revenues: Northern Nigeria, 1931-1932, Microform ID: 73242B-22, page 151. 
Table A9: Summary of British budget data

\begin{tabular}{lccccc}
\hline \hline Statistic & $\mathrm{N}$ & Mean & St. Dev. & Min & Max \\
\hline Total revenue (log) & 147 & 13.38 & 1.22 & 9.01 & 16.42 \\
Revenue from: Taxes (log) & 147 & 12.78 & 1.22 & 8.56 & 16.26 \\
.. Fees \& fines (log) & 147 & 11.48 & 1.35 & 7.88 & 15.22 \\
.. Transfers (log) & 147 & 6.76 & 5.65 & 0.00 & 15.18 \\
.. Other (log) & 128 & 10.99 & 1.49 & 4.94 & 14.37 \\
Total expenitures (log) & 127 & 13.60 & 1.12 & 8.85 & 16.47 \\
Expenditures on: Administration (log) & 127 & 12.25 & 1.20 & 6.92 & 15.54 \\
.. Order (log) & 127 & 11.77 & 0.89 & 8.25 & 14.34 \\
.. Education \& health (log) & 127 & 11.42 & 1.66 & 0.00 & 14.44 \\
.. Agriculture (log) & 127 & 9.13 & 2.19 & 0.00 & 13.99 \\
.. Public works (log) & 127 & 12.13 & 1.31 & 7.47 & 15.49 \\
. Other (log) & 127 & 10.93 & 1.57 & 5.81 & 15.65 \\
Precolonial centralization & 146 & 1.55 & 0.71 & 0.00 & 3.00 \\
Population (log) & 146 & 12.25 & 0.77 & 9.71 & 14.89 \\
Area (log) & 146 & 2.16 & 0.11 & 1.89 & 2.43 \\
Population density (log, 1880) & 146 & 3.00 & 0.96 & 0.84 & 5.25 \\
Ethnic groups' pop. density (log, 1880$)$ & 146 & 3.03 & 0.87 & 1.02 & 4.52 \\
Distance to coast (log) & 146 & 5.31 & 1.28 & 0.14 & 7.07 \\
Distance to nav. river (log) & 146 & 4.41 & 0.84 & 2.48 & 5.99 \\
Median altitude & 146 & 383.91 & 386.85 & 8.77 & 1756.29 \\
Median slope & 146 & 3.78 & 1.18 & 1.67 & 7.49 \\
Mean temperature & 146 & 25.77 & 2.20 & 18.58 & 28.97 \\
Evapotranspiration & 146 & 1572.15 & 257.01 & 1195.29 & 2318.16 \\
Precipitation & 146 & 1444.26 & 530.15 & 485.48 & 2835.08 \\
Evapotranspiration/Precipitation & 146 & 5.08 & 1.30 & 2.04 & 8.00 \\
Agricultural suitability & 146 & 0.45 & 0.19 & 0.01 & 0.89 \\
Cash crop suitability & 146 & 0.40 & 0.11 & 0.08 & 0.72 \\
Reliance on agriculture & 146 & 1.37 & 0.72 & 0.00 & 3.78 \\
Reliance on pastoralism & 146 & 6.71 & 1.13 & 3.12 & 9.00 \\
Intensity of agriculture & 146 & 2.14 & 0.29 & 2.00 & 3.00 \\
\hline
\end{tabular}




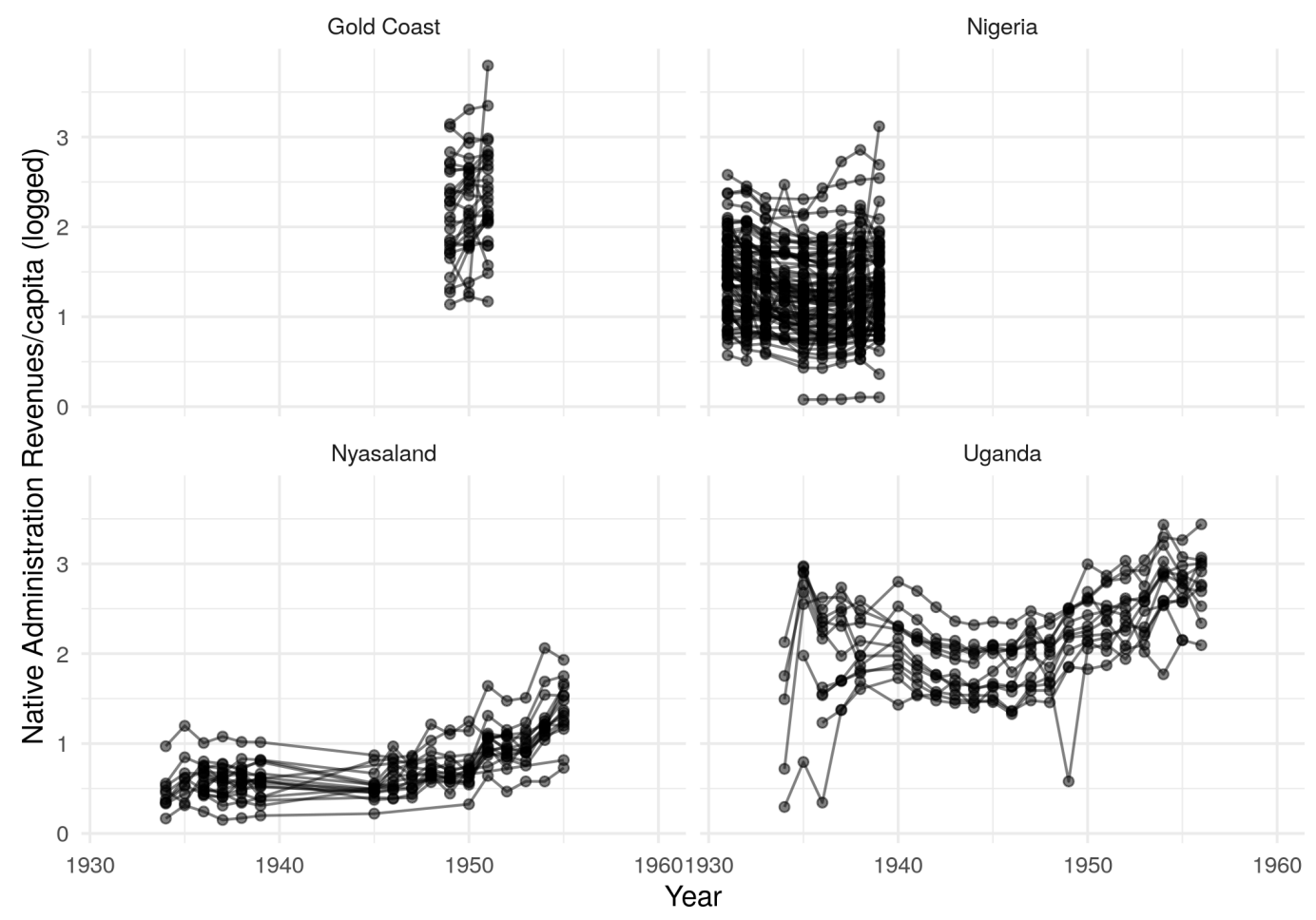

Figure A6: Per-capita revenues of native treasuries over time (logged; $2016 £$ ). Aggregated to the district level.

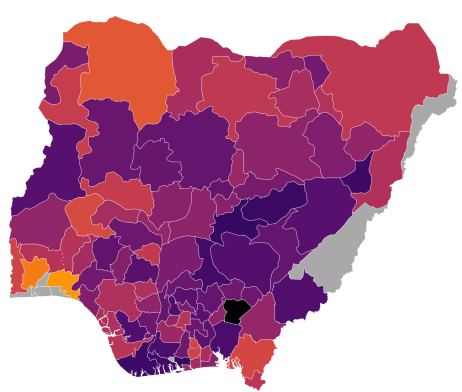

(a) Nigeria 1931-1939

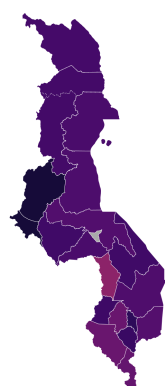

(b) Nyasa-(c) Gold Coast, land, $\quad$ 1949-1951 $1934-1955$

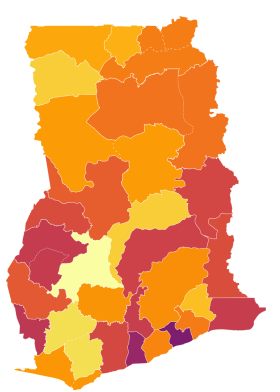

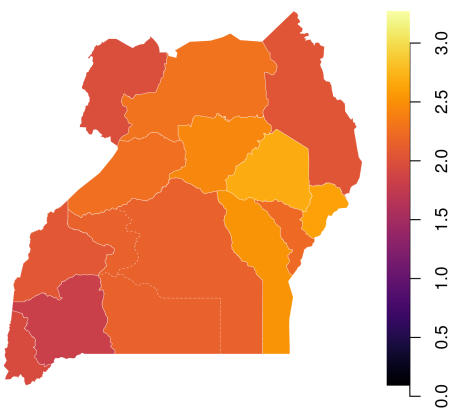

(d) Uganda 1934-1956

Figure A7: Per-capita revenues of native treasuries (logged; $2016 £$ ). Aggregated to the district level and averaged over all observed years. 


\section{A1.4 Correlations between indicators of British indirect rule}

In order to gauge in how far the various measures of indirect rule used as dependent variables in the main analysis correlate with each other and thus consistently capture "indirect rule," Figure A8 displays the correlation matrix of all four measures. All outcomes are correlated with each other, but not perfectly. This supports the view that they capture varying aspects of indirect rule.

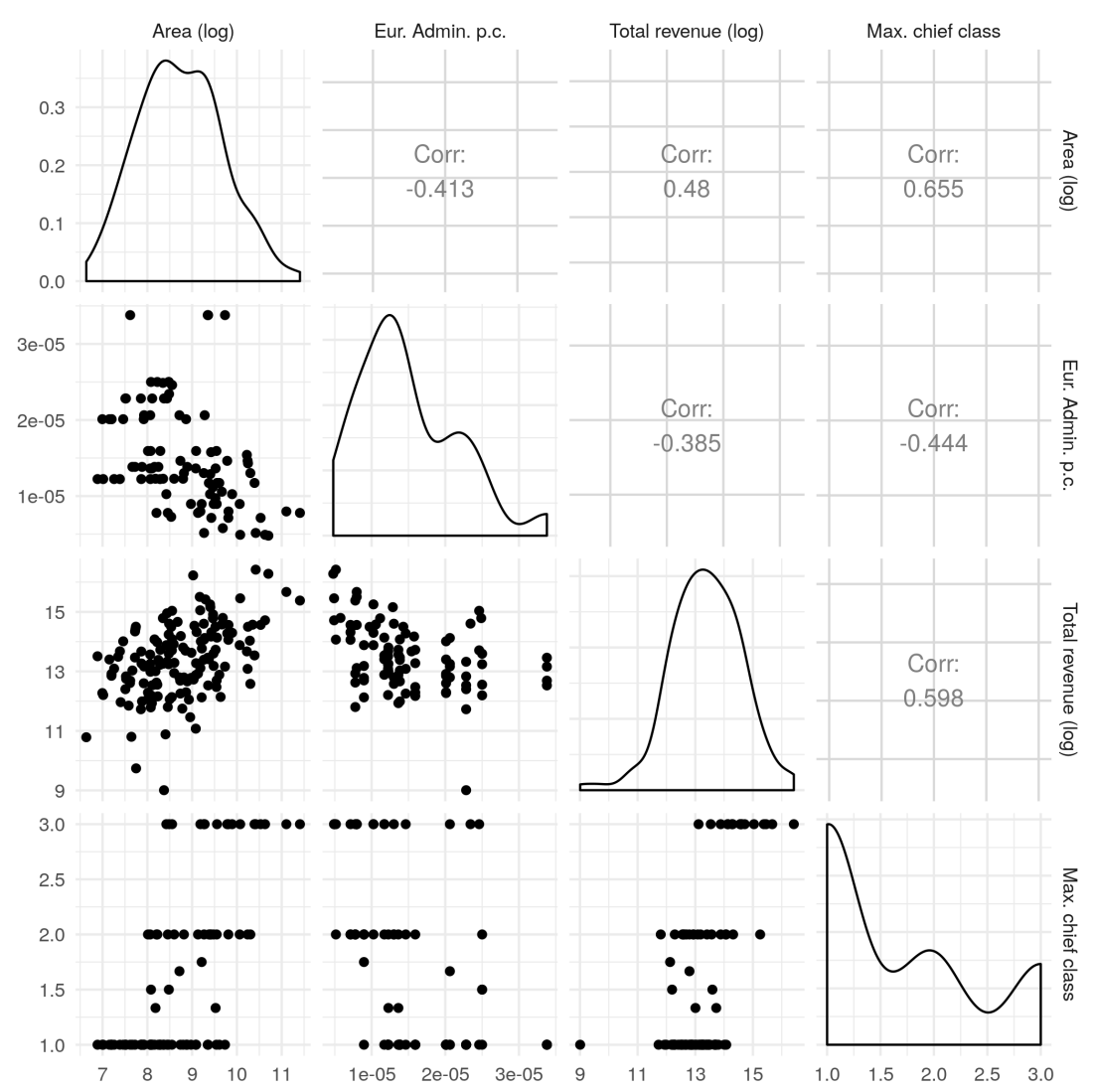

Figure A8: Correlations between four main measures of British indirect rule.

\section{A2 Evidence from the survival of lines of succession}

This section presents a set of supplementary analyses of the effect of French and British rule on the demise of precolonial polities in Africa. Subsection A2.1 discusses the robustness checks to the baseline models mentioned in the main text. In Subsection A2.5, I exploit variation within West Africa and along its coast to increase the internal validity of the research design. Lastly, Subsection A2.1 shows how British and French colonization led to the death and deposition of individual rulers, mainly right after colonization. 


\section{A2.1 Main robustness checks}

Three types of robustness checks are applied to the baseline model including all control variables in Table 2 of the main text. First, Models 1 and 2 in Table A10 address the imbalance in the sample with regards to the number of polities from the French and British empires as well as from the various colonies therein. Weighting observations such that each empire (Model 1) and colony (Model 2) receives equal weight substantially increases the coefficient associated with British rule from 1.8 to 2.4 and 2.9, respectively. This suggests that giving the British empire and the colony of Nigeria more weight in the baseline specification leads to more conservative estimates.

Model 3 stratifies the data by year ${ }^{136}$ in order to avoid that different timings of the French and British colonization bias the results. Doing so does not change the the baseline coefficient but increases its standard error $(p<.1)$. Thus, variation in the timing of colonization does not explain the difference between the French and British style of colonial conquest. Lastly, Model 4 adds additional control variables for the local disease environment measured through the local suitability for the transmission of the malaria vector between mosquitoes (Gething et al., 2011) and an estimate of the local suitability for the Tsetse fly (Programme Against African Trypanosomosis, 1999). Including the two additional controls slightly increases the estimated effect of British colonial rule.

Table A10: British vs. French rule and the demise of precolonial polities: Robustness checks

\begin{tabular}{lcccc}
\hline \hline & \multicolumn{4}{c}{ End of line of succession } \\
\cline { 2 - 5 } & $(1)$ & $(2)$ & $(3)$ & $(4)$ \\
\hline British rule & $-2.397^{* * *}$ & $-2.916^{* *}$ & $-1.815^{*}$ & $-2.357^{* * *}$ \\
& $(0.846)$ & $(1.266)$ & $(1.035)$ & $(0.711)$ \\
& & & & \\
\hline Robustness check: & empire & colony & stratified & desease \\
& weights & weights & by year & controls \\
Baseline controls: & yes & yes & yes & yes \\
Nature controls: & yes & yes & yes & yes \\
Ethnic controls: & yes & yes & yes & yes \\
Observations & 4,581 & 4,581 & 4,581 & 4,581 \\
$\mathrm{R}^{2}$ & 0.00001 & 0.001 & 0.006 & 0.010 \\
Max. Possible $\mathrm{R}^{2}$ & -0.00003 & 0.002 & 0.014 & 0.055 \\
Log Likelihood & 0.091 & -2.248 & -19.910 & -105.428 \\
\hline \hline
\end{tabular}

Notes: Cox Proportional Hazard models. Standard errors are clustered on the polity-level. Baseline controls consist of the 1880 population density (logged), the distance to the coast (logged), the age of a polity (loged), and a linear time trend. Nature controls consist of median altitude and slope, mean annual temperature, precipitation and evapotranspiration, the ratio of the two, agricultural suitability, and soils' suitability for cash crop production. Ethnic controls consist of the reliance on agriculture and pastoralism, as well as the intensity of agricultural activities. Significance codes: ${ }^{*} \mathrm{p}<0.1 ;{ }^{* *} \mathrm{p}<0.05 ;{ }^{* * *} \mathrm{p}<0.01$.

\footnotetext{
${ }^{136}$ This is equivalent to adding year fixed effects.
} 
Lastly, the uncertainty associated with the results might vary with the level on which standard errors are clustered - so far on the level of individual polities. To gauge the effect of such clustering, Table A11 clusters standard errors (1) not at all, (2) the level of polities (the baseline specification), (3) on the level of colonies, and (4) ethnic groups (from Murdock's Atlas, 1959). The results show that the baseline clustering on the level of polities produces the most conservative standard errors.

Table A11: British vs. French rule and the demise of precolonial polities: Standard error clustering

\begin{tabular}{lcccc}
\hline \hline & \multicolumn{4}{c}{ End of line of succession } \\
\cline { 2 - 5 } & $(1)$ & $(2)$ & $(3)$ & $(4)$ \\
\hline British rule & $-1.787^{* * *}$ & $-1.787^{* * *}$ & $-1.787^{* * *}$ & $-1.787^{* * *}$ \\
& $(0.544)$ & $(0.600)$ & $(0.507)$ & $(0.600)$ \\
\hline SE clusters: & & & colony & ethnic group \\
Baseline controls: & none & polity & yes & yes \\
Nature controls: & yes & yes & yes & yes \\
Ethnic controls: & yes & yes & yes & yes \\
Observations & 4,581 & 4,581 & 4,581 & 4,581 \\
$\mathrm{R}^{2}$ & 0.009 & 0.009 & 0.009 & 0.009 \\
Max. Possible $\mathrm{R}^{2}$ & 0.055 & 0.055 & 0.055 & 0.055 \\
Log Likelihood & -108.471 & -108.471 & -108.471 & -108.471 \\
\hline \hline
\end{tabular}

Notes: Cox Proportional Hazard models. Standard errors are clustered on the polity-level. Baseline controls consist of the 1880 population density (logged), the distance to the coast (logged), the age of a polity (loged), and a linear time trend. Nature controls consist of median altitude and slope, mean annual temperature, precipitation and evapotranspiration, the ratio of the two, agricultural suitability, and soils' suitability for cash crop production. Ethnic controls consist of the reliance on agriculture and pastoralism, as well as the intensity of agricultural activities. Significance codes: ${ }^{*} \mathrm{p}<0.1 ;{ }^{* *} \mathrm{p}<0.05 ;{ }^{* * *} \mathrm{p}<0.01$.

\section{A2.2 Linear models}

Table A12 presents the results of a linear probability model of the rate of survival of colonized polities until their respective countries' independence. The table substantiates the insights from the raw correlation of British rule with a higher survival rate plotted in Figure 4 in the main text. The coefficient British rule in Models 1-3 shows that polities under British rule had a 25-32 percentage points higher chance of surviving colonial rule than those under French rule.

In a similar vein and to check whether the choice of estimating Cox Proportional Hazard Models drives the results, Table A13 presents the results of liner hazard models. The models take the following specification:

$$
\mathrm{h}_{i, t}=\alpha_{t}+\beta_{1} \text { British }_{i}+\boldsymbol{X}_{1} \boldsymbol{\Lambda}_{i}+\boldsymbol{X}_{2} \boldsymbol{\Omega}_{i}+\boldsymbol{X}_{3} \boldsymbol{\Psi}_{i}+\epsilon_{i},
$$

where the hazard $h$ of polity $i$ to experience the end of its line of succession is 
Table A12: British vs. French rule and the demise of precolonial polities: OLS

\begin{tabular}{lccc}
\hline \hline & \multicolumn{3}{c}{ Reaches independence } \\
\cline { 2 - 4 } & $(1)$ & $(2)$ & $(3)$ \\
\hline British rule & $0.318^{* * *}$ & $0.312^{* *}$ & $0.251^{*}$ \\
& $(0.097)$ & $(0.123)$ & $(0.135)$ \\
\hline Baseline controls: & yes & yes & yes \\
Nature controls: & no & yes & yes \\
Ethnic controls: & no & no & yes \\
Observations & 116 & 112 & 102 \\
$\mathrm{R}^{2}$ & 0.129 & 0.221 & 0.269 \\
Adjusted $\mathrm{R}^{2}$ & 0.081 & 0.108 & 0.111 \\
\hline \hline
\end{tabular}

Notes: Linear probability models. Standard errors are clustered on the politylevel. Baseline controls consist of the 1880 population density (logged), the distance to the coast (logged), the age of a polity (loged), and a linear time trend. Nature controls consist of median altitude and slope, mean annual temperature, precipitation and evapotranspiration, the ratio of the two, agricultural suitability, and soils' suitability for cash crop production. Ethnic controls consist of the reliance on agriculture and pastoralism, as well as the intensity of agricultural activities. Significance codes: ${ }^{*} \mathrm{p}<0.1 ;{ }^{* *} \mathrm{p}<0.05 ;{ }^{* * *} \mathrm{p}<0.01$.

dependent on the baseline hazard in a given year after colonization $t$, the identity of the colonizer (British), and the series of control variables (see above). Sequentially adding the vectors of control, the results show that, in any given year, polities under British rule had a 1.6 percentage points lower hazard of experiencing the end of their line of succession. Although the uncertainty associated with this estimate increases as more control variables are added to the model, the point estimate does not change. If we aggregate this difference in the yearly hazard up to the total duration of colonial rule $(\approx 80$ years $)$, we arrive at almost the same difference in the average probability of surviving colonial rule than estimated above in Table A12: $(1-.016)^{80}=.275$. Hence, the linear models reaffirm the main insight from the Hazard Models, namely that polities under French rule were 30 percentage points less likely to survive colonial rule than those under British rule. 
Table A13: British vs. French rule and the demise of precolonial polities: OLS

\begin{tabular}{lccc}
\hline \hline & \multicolumn{3}{c}{ End of line of succession } \\
\cline { 2 - 4 } & $(1)$ & $(2)$ & $(3)$ \\
\hline British rule & $-0.016^{* * *}$ & $-0.016^{* *}$ & $-0.017^{*}$ \\
& $(0.006)$ & $(0.007)$ & $(0.009)$ \\
\hline Year since conquest FE: & & & yes \\
Baseline controls: & yes & yes & yes \\
Nature controls: & no & yes & yes \\
Ethnic controls: & no & no & yes \\
Observations & 5,208 & 4,902 & 4,581 \\
$\mathrm{R}^{2}$ & 0.078 & 0.086 & 0.066 \\
Adjusted $\mathrm{R}^{2}$ & 0.059 & 0.065 & 0.042 \\
\hline \hline
\end{tabular}

Notes: Linear probability models. Standard errors are clustered on the politylevel. Baseline controls consist of the 1880 population density (logged), the distance to the coast (logged), the age of a polity (loged), and a linear time trend. Nature controls consist of median altitude and slope, mean annual temperature, precipitation and evapotranspiration, the ratio of the two, agricultural suitability, and soils' suitability for cash crop production. Ethnic controls consist of the reliance on agriculture and pastoralism, as well as the intensity of agricultural activities. Significance codes: ${ }^{*} \mathrm{p}<0.1 ;{ }^{* *} \mathrm{p}<0.05 ;{ }^{* * *} \mathrm{p}<0.01$.

\section{A2.3 Colony-level jackknife}

In order to assess in as how far the results are driven by precolonial polities located in different colonies conquered by either the British or the French, I re-estimate the three baseline models in Table 2 in the main text, iteratively dropping observations in each colony. The results of this exercise are plotted in Figure A9. They show point estimates that are robust to dropping each colony, indicating that the results are not driven by observations from any single colony. The only exception consists in the fully specified model that includes all 'nature' and 'ethnic' control variables, which features a considerably larger standard error of 'British rule' once polities in Nigeria are dropped $(p=.24)$ but a point estimate $(-1.08)$ not far removed from that of the baseline model. This deviation is in large part due to the drastically decreased sample size caused by dropping the 52 polities located in Nigeria which make up 42 percent of the entire sample of polities observed. In addition, the fact that the results remain stable in the models on the sample without Nigeria and without 'ethnic covariates' speaks to the robustness of the results. Furthermore and as explained in Subsection A2.5 below, polities in Nigeria are crucial for the comparison between French and British polities which is best identified in coastal West Africa where French and British colonies featured very similar conditions. This comparison is naturally not captured in the jackknife models when Nigerian cases are dropped from the sample. 

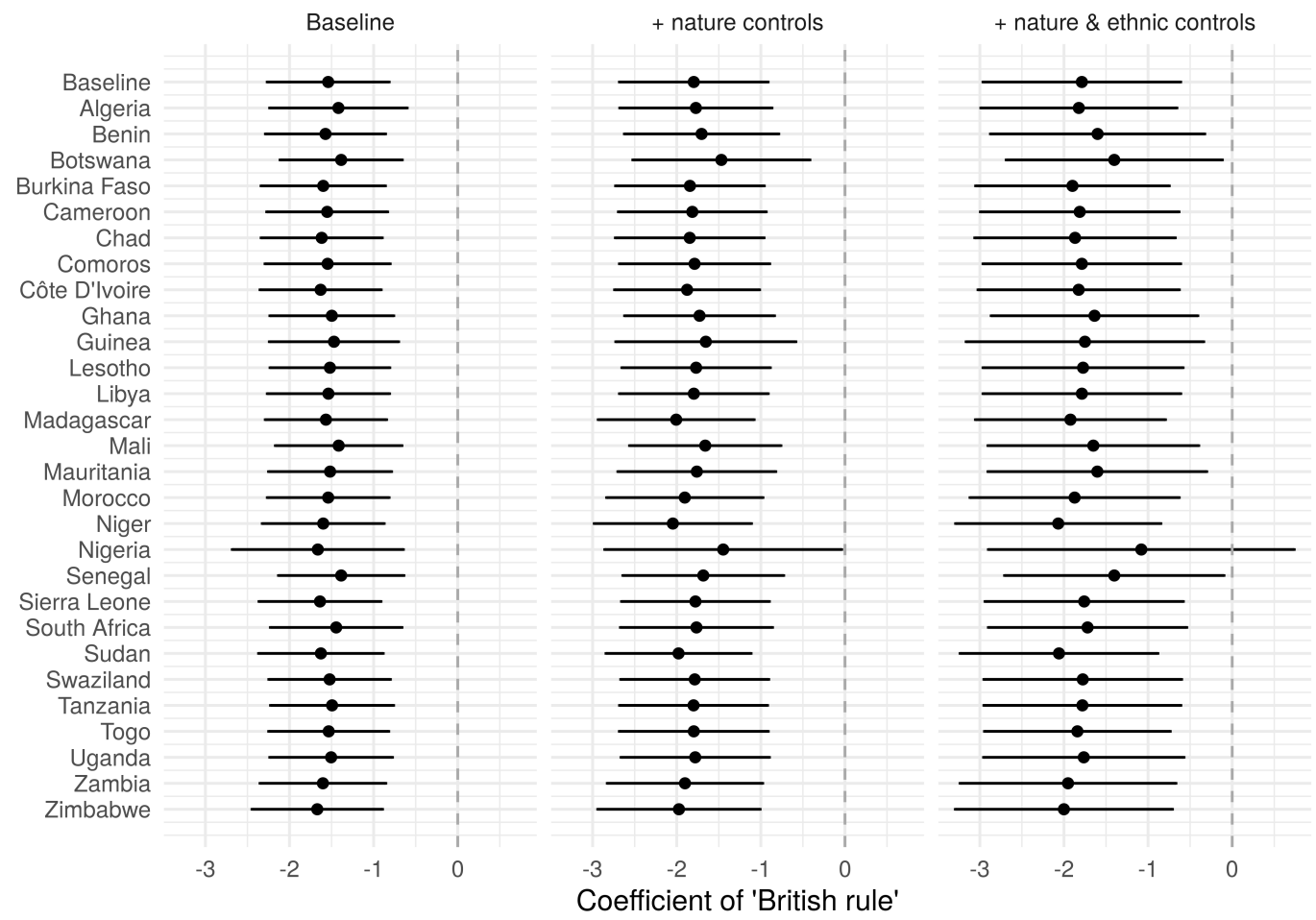

Figure A9: Colony-level jackknife: Estimated effects estimated when iteratively dropping each colony from the sample.

\section{A2.4 Survival of rulers before and after colonization}

The data gathered from Stewart's (2006) encyclopedia on states and rulers in Africa allows us to further zoom into the demise of polities. Using the tenure time of each individual ruler for which Stewart provides us with data, ${ }^{137}$ we can compare the average tenure lengths of rulers of the same polity before and after colonization by either the British, the French, or another colonizer. By restricting the analysis to variation within a polity, I control for all polity-specific attributes that might affect the length of rule of one ruler - in particular its political system and natural (disease) environment.

Figure A10 plots the basic intuition behind the approach. It shows descriptively how up to the point of colonization, the probability of a ruler to be deposed in a given year does not change much. However, it rises sharply with colonization by either the British or the French although substantively more so in the case of the latter. In the first year of colonization by the French almost $50 \%$ of all rulers got deposed. In the case of British colonization, that percentage stands at $35 \%$, as compared to a baseline probability of around $10 \%$.

Modeling the data in a Cox Proportional Hazard Models stratified by each

\footnotetext{
${ }^{137} 10 \%$ of all rulers are associated with missing start or end dates.
} 


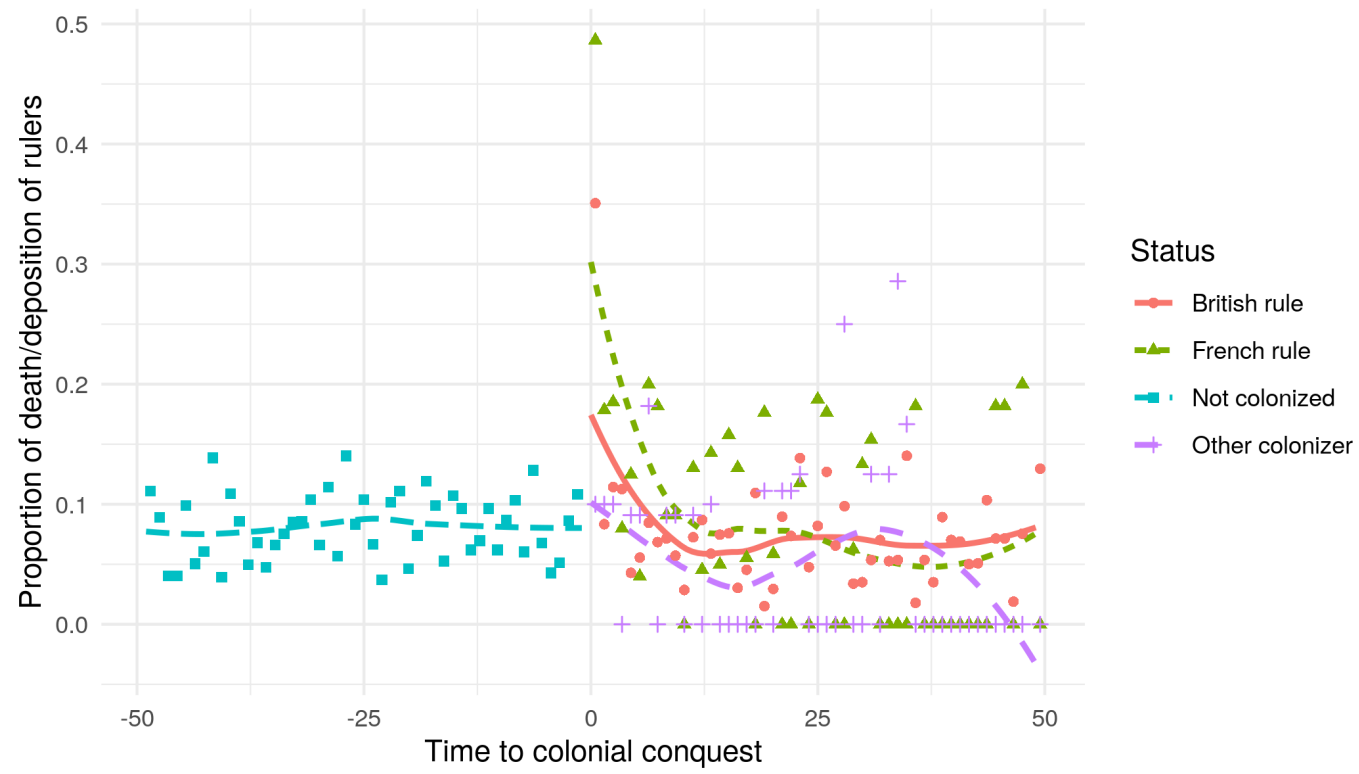

Figure A10: Colony-level jackknife: Estimated effects of British rule on the risk of the end of lines of succession when iteratively dropping each colony from the sample.

polity's capital ${ }^{138}$ in Table A14 shows that the difference between the effect of British and French colonization on ruler's deposition is indeed statistically significant and of meaningful size. Model 1 compares the average deposition probabilities within polities before and after colonization, in a sample restricted to observations post1500. Colonization by the French is treated as the reference category to ease the interpretation of the coefficient of British rule which is statistically significant and of meaningful size: In a given year, rulers under British rule are $73 \%$ as likely to get deposed as under French rule. To identify the effect of colonization right when it began, Model 2 then adds linear pre- and post-trends for each of the four states in which polities can be: either not colonized, or colonized by the British, the French, or another colonizer (see Figure A10). Model 3 adds also quadratic terms of these. Because they pick up the non-linear increase in survival rates in the years after colonization (see Figure A10), the models with trends yield larger differences between the French and the British colonization: with quadratic trends, rulers under British rule are only $62 \%$ as likely as French rulers to be deposed or killed in the year of colonization. Lastly, by adding a dummy for the demise of a ruler's polity to the estimation, Model 4 shows that these difference are mostly due the comparatively heavy hand of the French towards the colonized polities and not only to their rulers. While the coefficient of the demise of a polity is (naturally) highly significant, the difference between the French and the British is now associated with a smaller

\footnotetext{
${ }^{138}$ Stratifying by polity-capital rather than polity has the advantage that doing so holds all environmental variables constant.
} 
coefficient that is statistically insignificant.

Table A14: Death/deposition of rulers before and during colonial rule (1500-): Cox Proportional Hazards

\begin{tabular}{|c|c|c|c|c|}
\hline & \multicolumn{4}{|c|}{ Death/deposition of ruler } \\
\hline & $(1)$ & $(2)$ & $(3)$ & $(4)$ \\
\hline British rule & $\begin{array}{c}-0.323^{* *} \\
(0.158)\end{array}$ & $\begin{array}{c}-0.431^{* *} \\
(0.200)\end{array}$ & $\begin{array}{c}-0.468^{* *} \\
(0.230)\end{array}$ & $\begin{array}{r}-0.275 \\
(0.235)\end{array}$ \\
\hline Other colonizer & $\begin{array}{c}0.327 \\
(0.308)\end{array}$ & $\begin{array}{c}0.057 \\
(0.367)\end{array}$ & $\begin{array}{c}-0.337 \\
(0.441)\end{array}$ & $\begin{array}{r}-0.126 \\
(0.443)\end{array}$ \\
\hline Not (yet) colonized & $\begin{array}{c}-0.278^{* *} \\
(0.139)\end{array}$ & $\begin{array}{c}-0.600^{* * *} \\
(0.164)\end{array}$ & $\begin{array}{c}-0.766^{* * *} \\
(0.189)\end{array}$ & $\begin{array}{c}-0.472^{* *} \\
(0.192)\end{array}$ \\
\hline Polity age (log) & $\begin{array}{c}0.001^{* * *} \\
(0.0003)\end{array}$ & $\begin{array}{c}-0.003 \\
(0.003)\end{array}$ & $\begin{array}{c}-0.005 \\
(0.005)\end{array}$ & $\begin{array}{c}-0.006^{* *} \\
(0.003)\end{array}$ \\
\hline End of line of succession & & & & $\begin{array}{l}2.615^{* * *} \\
(0.284)\end{array}$ \\
\hline Strata: & capital & capital & capital & capital \\
\hline Running linear: & no & yes & yes & yes \\
\hline Running quadratic: & no & no & yes & yes \\
\hline Sample: & post- 1500 & post- 1500 & post-1500 & post- 1500 \\
\hline Observations & 25,328 & 25,328 & 25,328 & 25,328 \\
\hline $\mathrm{R}^{2}$ & 0.001 & 0.002 & 0.002 & 0.005 \\
\hline Max. Possible $\mathrm{R}^{2}$ & 0.240 & 0.240 & 0.240 & 0.240 \\
\hline Log Likelihood & $-3,460.952$ & $-3,454.023$ & $-3,448.067$ & $-3,420.846$ \\
\hline
\end{tabular}

${ }^{*} \mathrm{p}<0.1 ;{ }^{* *} \mathrm{p}<0.05 ;{ }^{* * *} \mathrm{p}<0.01$. Standard errors are clustered on the ruler-level.

\section{A2.5 The demise of polities in (coastal) West Africa}

One question the previous analyses cannot fully answer is whether the results are driven by endogenous colonization choices of the French and British conquerors. Although the ruler-level analysis above (Subsection A2.4) exploits within polity variation, it might still be that various local (e.g. environmental) factors make a certain area more or less difficult to colonize. If the British systematically colonized areas in which indirect rule was inherently easier to carry out, the results above might be solely due to that choice rather than due to the fact that the British rather than the French conquered a certain precolonial polity. In order to further zoom in on that relevant counterfactual, I exploit variation in the demise of polities first in West Africa and particularly along its coast, where the regions which were colonized by the British and the French are arguably exogenous. In that regard, Models 1 ad 2 in Table A16 restrict the sample to all French and British colonies in West Africa. Models 3 and 4 only rely on polities observed in colonies along the 
West African coast.

Finally, Models 5 and 6 exploit only variation across French-British borders that run perpendicular to the West African coast. ${ }^{139}$ Because they resulted from the race of the colonizers towards the inner parts of the continent (Cogneau and Moradi, 2014; Wesseling, 1996), these borders run at an angle of $90^{\circ}$ from the coast and come closest to a "natural experiment" that allows us to draw counterfactual inferences. These last two specification thus stratify the Cox Proportional Hazard estimate by the perpendicular border closest to each polity. Stratified baseline hazards are estimated as a conditional logistic regression, avoiding the incidental parameter problem. The models thus compare polities only across these borders, similar to a linear model with border and year-since-colonization fixed effects. Because the relatively few polities around the perpendicular borders are unevenly distributed in space, I cannot estimate a sharp discontinuity at the borders.

Indeed, the balance Table A15 shows that the strategy of sequentially narrowing the range of comparisons to polities in ever closer geographical areas is successful in reducing the imbalance of the sample on pre-treatment covariates of polities. However, significant imbalances of polities' distance to the costs and navigable rivers as well as of their agricultural suitability remain so that even the cross-border sample is not perfectly balanced. This underlines the need to control for observed covariates.

The results of this analysis point towards even greater differences in the probability of polities' demise in the British and French colonies than estimated at baseline. While the size of the estimated hazard ratios ranges significantly - in particular once covariates are added in Models 2, 4, and 6 - but mostly smaller than the one estimated at baseline $(.23) .{ }^{140}$ Once the model is stratified across borders, the estimates are less precise $\mathrm{p}<.1$ ). In sum, these patterns suggest that the baseline results are not caused by endogenous choices of the French and British which areas of the African continent to colonize.

\footnotetext{
${ }^{139}$ From West to East: Côte d'Ivoire-Gold Coast-French Togo Mandate-Dahomey-NigeriaCameroon.

${ }^{140}$ This means that, in a given year, a polity is a quarter as likely to be demised under British than under French rule.
} 
Table A15: Balance test, standardized coefficients

\begin{tabular}{|c|c|c|c|c|}
\hline & All & West Africa & West African Coast & X-Border \\
\hline $\begin{array}{l}\text { Indep. variable } \\
\text { Dep. variable }\end{array}$ & British & British & British & British \\
\hline Population (log) & $\begin{array}{c}0.055 \\
(0.268)\end{array}$ & $\begin{array}{l}0.789^{* * *} \\
(0.286)\end{array}$ & $\begin{array}{c}0.779^{*} \\
(0.436)\end{array}$ & $\begin{array}{c}0.092 \\
(0.411)\end{array}$ \\
\hline Distance to coast (log) & $\begin{array}{c}0.524^{*} \\
(0.307)\end{array}$ & $\begin{array}{c}0.163 \\
(0.345)\end{array}$ & $\begin{array}{c}0.928^{* *} \\
(0.412)\end{array}$ & $\begin{array}{l}1.068^{* *} \\
(0.480)\end{array}$ \\
\hline Distance to river (log) & $\begin{array}{r}-0.263 \\
(0.316)\end{array}$ & $\begin{array}{c}0.196 \\
(0.345)\end{array}$ & $\begin{array}{r}-0.049 \\
(0.294)\end{array}$ & $\begin{array}{c}-0.358^{* * *} \\
(0.137)\end{array}$ \\
\hline Polity age (log) & $\begin{array}{c}-0.453^{* *} \\
(0.202)\end{array}$ & $\begin{array}{c}-0.358^{*} \\
(0.211)\end{array}$ & $\begin{array}{r}-0.114 \\
(0.194)\end{array}$ & $\begin{array}{c}0.060 \\
(0.257)\end{array}$ \\
\hline Dependence on agriculture & $\begin{array}{r}-0.407^{*} \\
(0.229)\end{array}$ & $\begin{array}{r}-0.532 \\
(0.329)\end{array}$ & $\begin{array}{r}-0.706 \\
(0.589)\end{array}$ & $\begin{array}{c}0.408 \\
(0.345)\end{array}$ \\
\hline Dependence on husbandry & $\begin{array}{r}-0.222 \\
(0.185)\end{array}$ & $\begin{array}{c}0.742^{* *} \\
(0.299)\end{array}$ & $\begin{array}{c}0.772 \\
(0.512)\end{array}$ & $\begin{array}{c}0.131 \\
(0.502)\end{array}$ \\
\hline Intensity of agriculture & $\begin{array}{c}-0.845^{* * *} \\
(0.274)\end{array}$ & $\begin{array}{r}-0.507 \\
(0.379)\end{array}$ & $\begin{array}{r}-1.094^{*} \\
(0.579)\end{array}$ & $\begin{array}{c}-0.831 \\
(0.569)\end{array}$ \\
\hline Precol. centralization & $\begin{array}{c}-0.741^{* * *} \\
(0.241)\end{array}$ & $\begin{array}{c}-0.641^{* *} \\
(0.255)\end{array}$ & $\begin{array}{r}-0.291 \\
(0.319)\end{array}$ & $\begin{array}{c}0.235 \\
(0.247)\end{array}$ \\
\hline Altitude (median) & $\begin{array}{c}0.484^{* *} \\
(0.224)\end{array}$ & $\begin{array}{c}0.114 \\
(0.257)\end{array}$ & $\begin{array}{c}0.467 \\
(0.336)\end{array}$ & $\begin{array}{c}0.241 \\
(0.423)\end{array}$ \\
\hline Slope (median) & $\begin{array}{c}0.315 \\
(0.250)\end{array}$ & $\begin{array}{c}0.364 \\
(0.309)\end{array}$ & $\begin{array}{c}0.687^{*} \\
(0.403)\end{array}$ & $\begin{array}{c}0.768 \\
(0.576)\end{array}$ \\
\hline Temperature (mean) & $\begin{array}{r}-0.285 \\
(0.302)\end{array}$ & $\begin{array}{c}-0.636^{* *} \\
(0.252)\end{array}$ & $\begin{array}{r}-0.177 \\
(0.335)\end{array}$ & $\begin{array}{l}0.157 \\
(0.297)\end{array}$ \\
\hline Evapotranspiration & $\begin{array}{c}0.071 \\
(0.256)\end{array}$ & $\begin{array}{c}0.114 \\
(0.251)\end{array}$ & $\begin{array}{c}0.493^{* *} \\
(0.251)\end{array}$ & $\begin{array}{c}0.441 \\
(0.269)\end{array}$ \\
\hline Precipitation & $\begin{array}{c}0.145 \\
(0.249)\end{array}$ & $\begin{array}{c}0.598^{* *} \\
(0.257)\end{array}$ & $\begin{array}{c}0.288 \\
(0.361)\end{array}$ & $\begin{array}{c}-0.221 \\
(0.284)\end{array}$ \\
\hline Evapotransp. / precipitation & $\begin{array}{c}0.171 \\
(0.261)\end{array}$ & $\begin{array}{c}0.490^{*} \\
(0.275)\end{array}$ & $\begin{array}{c}0.142 \\
(0.378)\end{array}$ & $\begin{array}{r}-0.273 \\
(0.281)\end{array}$ \\
\hline Suitability for agr. & $\begin{array}{c}0.258 \\
(0.272)\end{array}$ & $\begin{array}{c}0.533^{* *} \\
(0.271)\end{array}$ & $\begin{array}{c}0.340 \\
(0.396)\end{array}$ & $\begin{array}{c}-0.798^{* *} \\
(0.374)\end{array}$ \\
\hline Cash crop suitability & $\begin{array}{l}0.396^{* *} \\
(0.194)\end{array}$ & $\begin{array}{r}0.426^{*} \\
(0.251)\end{array}$ & $\begin{array}{l}0.741^{* *} \\
(0.306)\end{array}$ & $\begin{array}{c}0.151 \\
(0.406)\end{array}$ \\
\hline X-Border FE & no & no & no & yes \\
\hline Obs & 5208 & 3424 & 3026 & 2845 \\
\hline British & 0 & 0 & 0 & 0 \\
\hline French & 0 & 0 & 0 & 0 \\
\hline
\end{tabular}

${ }^{*} \mathrm{p}<0.1 ;{ }^{* *} \mathrm{p}<0.05 ;{ }^{* * *} \mathrm{p}<0.01$. Standard errors are clustered on the polity-level. 
Table A16: British vs. French rule and the demise of precolonial polities in West Africa

\begin{tabular}{|c|c|c|c|c|c|c|}
\hline & \multicolumn{6}{|c|}{ End of line of succession } \\
\hline & \multicolumn{2}{|c|}{ All West Africa } & \multicolumn{2}{|c|}{ Coastal West Africa } & \multicolumn{2}{|c|}{ x-Border Coastal W. A. } \\
\hline & $(1)$ & $(2)$ & $(3)$ & $(4)$ & $(5)$ & $(6)$ \\
\hline British rule & $\begin{array}{c}-1.28^{* *} \\
(0.55)\end{array}$ & $\begin{array}{c}-2.18^{* * *} \\
(0.83)\end{array}$ & $\begin{array}{c}-1.66^{* *} \\
(0.74)\end{array}$ & $\begin{array}{c}-2.53^{* *} \\
(1.21)\end{array}$ & $\begin{array}{r}-1.45^{*} \\
(0.86)\end{array}$ & $\begin{array}{r}-5.56^{*} \\
(3.07)\end{array}$ \\
\hline Strata: & - & - & - & - & Border & Border \\
\hline Baseline controls: & yes & yes & yes & yes & yes & yes \\
\hline Nature controls: & no & yes & no & yes & no & yes \\
\hline Ethnic controls: & no & yes & no & yes & no & yes \\
\hline Observations & 3,424 & 3,144 & 3,026 & 2,746 & 2,845 & 2,611 \\
\hline $\mathrm{R}^{2}$ & 0.01 & 0.01 & 0.01 & 0.01 & 0.003 & 0.01 \\
\hline Max. Possible $\mathrm{R}^{2}$ & 0.06 & 0.06 & 0.06 & 0.06 & 0.03 & 0.03 \\
\hline Log Likelihood & -100.93 & -82.78 & -81.42 & -64.53 & -34.84 & -20.79 \\
\hline
\end{tabular}

Notes: Cox Proportional Hazard models. Standard errors are clustered on the polity-level. Baseline controls consist of the 1880 population density (logged), the distance to the coast (logged), the age of a polity (loged), and a linear time trend. Nature controls consist of median altitude and slope, mean annual temperature, precipitation and evapotranspiration, the ratio of the two, agricultural suitability, and soils' suitability for cash crop production. Ethnic controls consist of the reliance on agriculture and pastoralism, as well as the intensity of agricultural activities. Significance codes: ${ }^{*} \mathrm{p}<0.1 ;{ }^{* *} \mathrm{p}<0.05 ;{ }^{* * *} \mathrm{p}<0.01$.

\section{A3 Evidence from colonial districts}

This section presents additional results for the analysis of the first dimension of indirect rule: the administrative effort employed by the colonial governments. This effort is proxied by two main variables: the size of colonial district, and the number of European administrators deployed at the local level. The main focus of the analysis lies on the size of districts for which data is more abundant and comparable across the French and British empires. Subsection A3.1 presents the main robustness checks and Subsection A3.3 discusses the more controlled comparisons of districts' sizes in the French and British colonies along the West African coastline. Lastly, Subsection A3.4 presents the results of the analysis of the association of precolonial centralization and the number of local British administrators.

\section{A3.1 Districts' size: Robustness checks}

Table A17 presents the robustness checks to the main analysis of the effect of precolonial centralization on districts' size (main text, Table 5). It addresses a number of issues which might bias the baseline results. First, Model 1 drops all outliers from the sample, some of which might drive the relationship between precolonial centralization and size in British colonies. Outliers are defined as very small and large districts in the upper and lower 2.5 percentiles of the data. Dropping them does not change the positive relation between precolonial centralization and districts' size in 
the British colonies. In the French colonies, this relation is slightly less negative than at baseline but significantly different from that in the British sample (see the interaction term). In order to avoid excessive weight for the large colonies - in particular Nigeria - which might bias the results, Model 2 weights each observation by the inverse of the number of observations from the colony it belongs to. Giving each colony equal weight leads to very similar results as at the baseline.

I then proceed as with the analysis of the survival of precolonial politites and add a districts' disease environment (Malaria and Tsetse suitability), both of which might have reduced the administrative effort of the British. These additional control variables do not change the results (Model 3). Model 4 replaces the measure of precolonial centralization provided by Murdock (1959) with a dummy for whether a district featured a capital in 1885 of one of the polities listed in Stewart's (2006) encyclopedia of African states and rulers (see Appendix A1.1 above) or not. The emerging pattern is consistent with the previous results: Districts in the British empire that featured a capital in 1885 are about 65 percent bigger than those that did not. ${ }^{141}$ This pattern is not discernible in French West Africa. This shows that the results are not due to arbitrary codings which might bias Murdock's data. Model 5 replace the the mapping of Murdock's Ethnographic Atlas (1967) to his ethnic map (1959) conducted by Nunn and Wantchekon (2011) with the slightly different coding from Michalopoulos and Papaioannou (2013). While their data lead to five more missing values, the results are very similar to the baseline estimates.

\footnotetext{
${ }^{141}$ This percent estimate results from the following equation: $(\exp (\beta)-1) * 100$
} 
Table A17: Precolonial centralization and the size of districts: Robustness checks

\begin{tabular}{|c|c|c|c|c|c|}
\hline & \multicolumn{5}{|c|}{$\log ($ District Area $)$} \\
\hline & $\begin{array}{c}\text { No outlier } \\
\text { (1) }\end{array}$ & $\begin{array}{c}\text { Col.-weight } \\
\text { (2) }\end{array}$ & $\begin{array}{c}\text { Disease } \\
(3)\end{array}$ & $\begin{array}{c}\text { Cap. } 1885 \\
(4)\end{array}$ & $\begin{array}{l}\text { Alt. PCC } \\
\text { (5) }\end{array}$ \\
\hline Precol. centralization & $\begin{array}{l}0.14^{* *} \\
(0.05)\end{array}$ & $\begin{array}{l}0.13^{* * *} \\
(0.05)\end{array}$ & $\begin{array}{l}0.13^{* * *} \\
(0.05)\end{array}$ & & \\
\hline Precol. centr. $\times$ French & $\begin{array}{c}-0.29^{* * *} \\
(0.11)\end{array}$ & $\begin{array}{c}-0.27^{* * *} \\
(0.10)\end{array}$ & $\begin{array}{c}-0.33^{* * *} \\
(0.10)\end{array}$ & & \\
\hline Capital 1885 & & & & $\begin{array}{l}0.50^{* * *} \\
(0.14)\end{array}$ & \\
\hline Capital $1885 \times$ French & & & & $\begin{array}{c}-0.36^{* *} \\
(0.18)\end{array}$ & \\
\hline Precol. centr. (MP) & & & & & $\begin{array}{l}0.17^{* * *} \\
(0.05)\end{array}$ \\
\hline Precol. centr. $(\mathrm{MP}) \times$ French & & & & & $\begin{array}{c}-0.30^{* * *} \\
(0.11)\end{array}$ \\
\hline Colony FE: & yes & yes & yes & yes & yes \\
\hline Colony weights: & no & yes & no & no & no \\
\hline Desease controls: & no & no & yes & no & no \\
\hline Baseline controls: & yes & yes & yes & yes & yes \\
\hline Nature controls: & yes & yes & yes & yes & yes \\
\hline Ethnic controls: & yes & yes & yes & yes & yes \\
\hline Mean DV & 9.11 & 9.14 & 9.14 & 9.14 & 9.15 \\
\hline Observations & 383 & 400 & 400 & 400 & 395 \\
\hline Adjusted $\mathrm{R}^{2}$ & 0.69 & 0.81 & 0.72 & 0.73 & 0.74 \\
\hline
\end{tabular}

Notes: OLS models. Standard errors are clustered on the province-level. Baseline controls include the local population density, ethnic groups' population density, and the distance to the coast as well as the closest navigable river. Nature controls consist of the local altitude and slope, mean annual temperature, precipitation and evapotranspiration, the ratio of the two, agricultural suitability, and soils' suitability for cash crop production. Ethnic controls are the reliance on agriculture and pastoralism, as well as the intensity of agricultural activities. Additionally, all covariates are interacted with 'French rule'. Significance codes: ${ }^{*} \mathrm{p}<0.1$; ${ }^{* *} \mathrm{p}<0.05 ;{ }^{* * *} \mathrm{p}<0.01$.

\section{A3.2 Colony-level jackknife}

As in the polity-survival analysis, I check the robustness of the results in the main district-size analysis presented in Table 5 in the main text to iteratively excluding every single colony in the sample. The results of this jackknife model are plotted in Figure A11. The plot shows that the results are not driven by observations from any single colony in the sample, including Nigeria.

There are a few, although unsystematic deviations from the baseline patterns observed in some specifications. Depending on the vector of covariates, the negative estimate for the effect of precol. centralization $\times$ French rule seems to be partly driven 

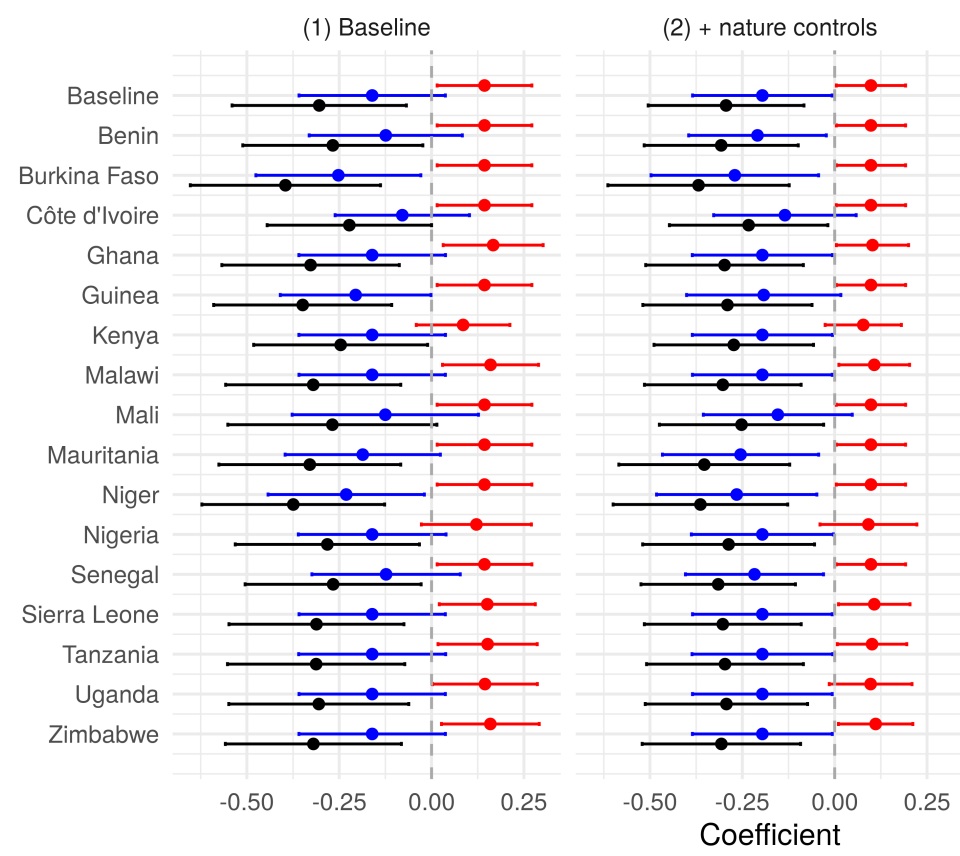

(3) + nature + ethnic controls

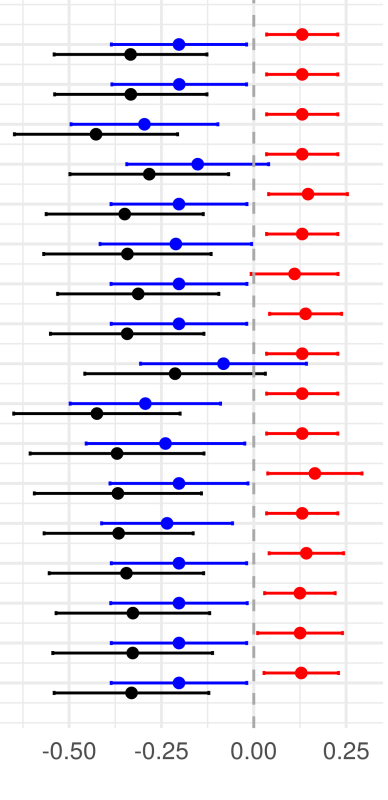

Figure A11: Colony-level jackknife: Estimated effects of precol. centralization on districts' size in British and French colonies when iteratively dropping each colony from the sample.

by observations from Mali (French Sudan) and becomes larger when we drop Burkina Faso (Upper Volta) and Niger. Similarly, in the Model without any covariates, the estimate of precol. centralization $\times$ British rule slightly drops when we exclude Kenya, and its standard errors becomes larger when Nigeria with its 96 districts (24\% of all observations) is excluded, although this does not affect the point estimates. The difference between the estimated effect of precol. centralization becomes less precisely estimated $(p<.1)$ when Mali is dropped from the sample in the fully specified model. In all, the lack of systematic influence of any colony on the estimates across specification speaks to the robustness of the baseline results. This is in particular the case since those colonies that affect the point estimates (Mali, Niger, Burkina Faso, and Kenya) are not part of the regression discontinuity analysis along French-British borders perpendicular to the West African African coast line presented below. This analysis accounts for omitted variables that may cause the variation observed in the jackknife analysis. 


\section{A3.3 Districts' size across French-British borders}

In the baseline specification, the identification of differences in districts' sizes within colonies and the difference of these patterns across the two empires rests on the assumption that there are no omitted variables. We can weaken this assumption and focus only on the difference of the effect of precolonial centralization on district sizes between the French and British empire. The identification of this difference rests on the assumption that French and British rule resembled a natural experiment, which is clearly not the case when comparing colonies across the entire continent. I therefore turn towards plausibly exogenous variation in the assignment of the ruling empire, the Nigeria-Benin and Gold Coast-Côte d'Ivoire borders in West Africa. Both borders are perpendicular to the coast line and emerged from a race of both colonizers towards the inner part of the continent (Wesseling, 1996). They can therefore be treated as-if random (Cogneau and Moradi, 2014) to identify the difference in the effect of precolonial institutions on administrative effort under French direct and British indirect rule.

In order to exploit the change in the effect of precolonial centralization on districts' size at the border, I turn towards an approach based on the centroids of grid cells. Using grid cell centroids as the main unit of the regression discontinuity design is warranted by the need to balance the number of observations across the FrenchBritish borders. Such balance is not achieved if one compares districts of varying size (which is the dependent variable), because larger districts are observed less often. Grid-cells in the main analysis ${ }^{142}$ have a size of .0833 decimal degrees or about $10 \mathrm{~km}$ at the equator. Each cell centroid is associated with the size of its district, the precolonial centralization of the ethnic group settling in it (from Murdock, 1959), as well as its distance to the next border. Because I am interested not in the pure effect of British or French colonial rule at the border, but its effect on the marginal effect of precolonial centralization, I estimate the following regression discontinuity:

$$
\begin{array}{r}
y_{i}=\alpha_{c}+\gamma_{b}+\beta_{1} \text { precol. }_{\text {centr. }}{ }_{i} \times \text { French }_{i}+\tau_{1} \text { Empire }_{i} \times \Delta_{i}+ \\
\tau_{2} \text { precol. centr. }_{i} \times \text { Empire }_{i} \times \Delta_{i}+\tau_{3} \text { precol. }_{\text {centr }}{ }_{i} \times \text { Border }_{i}+\epsilon_{i, p}
\end{array}
$$

The logic of this RD-design is illustrated in Figures A12a and A12b. The first figure plots the coefficient of precol. centralization on districts' size left and right of French-British borders in intervals of .5 decimal degrees. The second plots the marginal effect of centralization as a linear function of the distance to the border. As in common RDDs, we notice the trends in the effect of centralization on district sizes on both sides of the border. With $\Delta_{i}$ denoting the distance to the border, the absolute trends in district sizes are controlled for by the term Empire ${ }_{i} \times \Delta_{i}$, while

\footnotetext{
${ }^{142}$ See Figure A14 for a robustness check that varies the size of grid cells.
} 
Table A18: Balance test: Grid-cell level

\begin{tabular}{|c|c|c|c|}
\hline & All & RDD & $\mathrm{RDD}$ \\
\hline $\begin{array}{l}\text { Indep. variable } \\
\text { Dep. variable }\end{array}$ & Centr. $\times$ French & Centr. $\times$ French & Centr. $\times$ French \\
\hline Distance to coast (log) & $\begin{array}{l}-0.429^{* * *} \\
(0.109)\end{array}$ & $\begin{array}{r}-0.177^{*} \\
(0.101)\end{array}$ & $\begin{array}{r}-0.060 \\
(0.100)\end{array}$ \\
\hline Distance to nav. river $(\log )$ & $\begin{array}{r}-0.140 \\
(0.116)\end{array}$ & $\begin{array}{r}-0.236 \\
(0.302)\end{array}$ & $\begin{array}{r}-0.350 \\
(0.214)\end{array}$ \\
\hline Population density (log) & $\begin{array}{l}0.345^{* * *} \\
(0.100)\end{array}$ & $\begin{array}{c}0.194 \\
(0.167)\end{array}$ & $\begin{array}{c}0.147 \\
(0.120)\end{array}$ \\
\hline Ethnic groups' pop. dens. (log) & $\begin{array}{l}0.490^{* * *} \\
(0.108)\end{array}$ & $\begin{array}{c}0.240 \\
(0.184)\end{array}$ & $\begin{array}{c}0.065 \\
(0.124)\end{array}$ \\
\hline Dependence on agriculture & $\begin{array}{c}-0.257^{*} \\
(0.150)\end{array}$ & $\begin{array}{c}0.064 \\
(0.361)\end{array}$ & $\begin{array}{c}0.331 \\
(0.327)\end{array}$ \\
\hline Dependence on husbandry & $\begin{array}{c}0.113 \\
(0.138)\end{array}$ & $\begin{array}{r}-0.491 \\
(0.441)\end{array}$ & $\begin{array}{r}-0.503 \\
(0.436)\end{array}$ \\
\hline Intensity of agriculture & $\begin{array}{c}0.401 \\
(0.261)\end{array}$ & $\begin{array}{c}0.208 \\
(0.350)\end{array}$ & $\begin{array}{c}0.368 \\
(0.338)\end{array}$ \\
\hline Altitude & $\begin{array}{r}-0.064 \\
(0.087)\end{array}$ & $\begin{array}{c}-0.441^{* *} \\
(0.220)\end{array}$ & $\begin{array}{l}-0.617^{* * *} \\
(0.167)\end{array}$ \\
\hline Slope & $\begin{array}{c}0.195^{*} \\
(0.101)\end{array}$ & $\begin{array}{r}-0.283 \\
(0.179)\end{array}$ & $\begin{array}{r}-0.065 \\
(0.136)\end{array}$ \\
\hline Temperature & $\begin{array}{c}0.058 \\
(0.072)\end{array}$ & $\begin{array}{c}0.149 \\
(0.231)\end{array}$ & $\begin{array}{l}0.418^{* * *} \\
(0.153)\end{array}$ \\
\hline Evapotranspiration & $\begin{array}{r}-0.089 \\
(0.091)\end{array}$ & $\begin{array}{c}0.059 \\
(0.066)\end{array}$ & $\begin{array}{c}0.135^{*} \\
(0.073)\end{array}$ \\
\hline Precipitation & $\begin{array}{l}0.183^{* *} \\
(0.072)\end{array}$ & $\begin{array}{c}0.087 \\
(0.173)\end{array}$ & $\begin{array}{r}-0.073 \\
(0.159)\end{array}$ \\
\hline Evapotransp. / precipitation & $\begin{array}{l}0.153^{* *} \\
(0.071)\end{array}$ & $\begin{array}{c}0.125 \\
(0.125)\end{array}$ & $\begin{array}{c}-0.098 \\
(0.144)\end{array}$ \\
\hline Suitability for agr. & $\begin{array}{c}0.063 \\
(0.074)\end{array}$ & $\begin{array}{c}-0.366^{* *} \\
(0.152)\end{array}$ & $\begin{array}{c}0.021 \\
(0.164)\end{array}$ \\
\hline Cash crop suitability & $\begin{array}{c}0.156^{* *} \\
(0.062)\end{array}$ & $\begin{array}{c}0.074 \\
(0.193) \\
\end{array}$ & $\begin{array}{c}-0.461^{* *} \\
(0.191) \\
\end{array}$ \\
\hline RD-Design & no & yes & yes \\
\hline Cutoff (dec. degrees) & - & 5 & 2.5 \\
\hline Obs & 92954 & 13455 & 6456 \\
\hline British & 0 & 0 & 0 \\
\hline French & 0 & 0 & 0 \\
\hline
\end{tabular}

${ }^{*} \mathrm{p}<0.1 ;{ }^{* *} \mathrm{p}<0.05 ;{ }^{* * *} \mathrm{p}<0.01$. Standard errors are clustered on the province-level. 


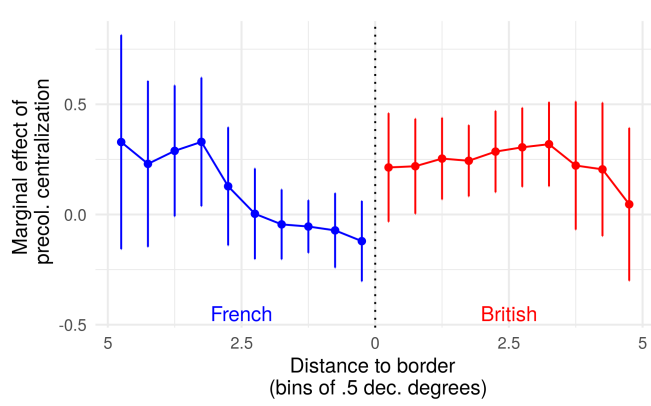

(a) RDD-plot discrete

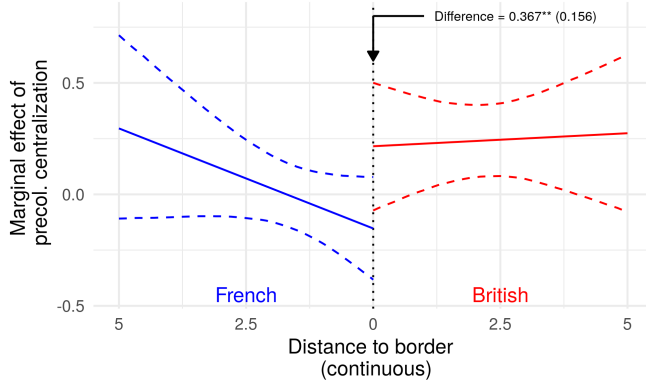

(b) RDD-plot continuous

Figure A12: Marginal effect of precolonial centralization left and right of FrenchBritish borders.

Point estimates in (a) and liner trends in (b) results from estimating Equation 2. For point estimates in (a), the continuous measure of the distance to the border $\Delta_{i}$ is cut into categorical bins of a size of .5 decimal degrees.

the trend in the effect of centralization is captured by the term precol. centr. ${ }_{i} \times$ Empire $_{i} \times \Delta_{i}$. To account for different levels in the effect of centralization in the two border-regions, I include the fixed slopes precol. centr. ${ }_{i} \times$ Border $_{i}$. Adding colony and border-segment fixed effects ${ }^{143} \alpha_{c}$ and $\gamma_{b}$, the main coefficient of interest, $\beta_{1}$ is driven by the jump in the marginal effect of precolonial centralization right at the border. To account for interdependencies between grid-cells and districts that are part of the same region, standard errors remain clustered on the level of provinces. ${ }^{144}$

Figure A12a shows that the trend in the effect of centralization on both sides of the border is reasonably smooth and well approximated by a linear term. Also, the plot shows a discrete jump of centralization's marginal effect on districts' size at the border. Lastly, the $\mathrm{RD}$-design requires that precolonial centralization has no such jump in its marginal association with any other pre-treatment variable. If that is the case, these pre-treatment variables, rather than precolonial centralization might drive the results. Table A18 shows few signs of such a jump. Choosing different distance cutoffs for the analysis at 5 and 2.5 decimal degrees $(\approx 500$ and $250 \mathrm{~km}$ ) balance is best for the wider bandwidth. Here, precol. centr. ${ }_{i} \times$ French $_{i}$ is only significantly related to cells altitude and agricultural suitability. Because this imbalance might drive the results, I estimate models with and without all co-variates as well as their interaction with French rule.

Table A19 presents the results. The first two columns show that precolonially centralized cells in the whole sample have become part of larger districts in the British, but not the French colonies. This suggests that the results from the district

\footnotetext{
${ }^{143}$ Note that I cut borders into segments according to distance-bins to the coastline of $100 \mathrm{~km}$ in order to increase the balance in the sample. This avoids that points in the North of Nigeria are compared with those in the South of Dahomey (Benin).

${ }^{144}$ Note that clustering on the level of districts leads to slightly smaller standard errors.
} 
level analysis carry over to the cell-level analysis. Models 3 and 4 then implement the RDD with a bandwidth of 5 decimal degrees, Models 5 and 6 with one of 2.5 decimal degrees, each time first without and then with all covariates. They all show that, at the border, the effect of precolonial centralization on district sizes decreases by about .35 log-points as one crosses from a British to a French colony. This effect of French rule on the marginal effect of precolonial centralization on district sizes is insignificantly bigger than that estimated at the baseline (.29-.33). The results are robust to the choice of bandwidth and adding the vectors of covariates. The latter suggests that the remaining and observed imbalances do not drive the results and further support the baseline estimates.

Table A19: Precolonial centralization and the size of districts: Grid-cells, RDD at French-British borders

\begin{tabular}{|c|c|c|c|c|c|c|}
\hline & \multicolumn{2}{|c|}{ All cells } & \multicolumn{4}{|c|}{ Regression Discontinuity Design } \\
\hline & $(1)$ & $(2)$ & $(3)$ & $(4)$ & $(5)$ & $(6)$ \\
\hline Precol. centralization & $\begin{array}{l}0.266^{* * *} \\
(0.087)\end{array}$ & $\begin{array}{l}0.184^{* * *} \\
(0.045)\end{array}$ & & & & \\
\hline Precol. centr. $\times$ French & $\begin{array}{c}-0.472^{* * *} \\
(0.133)\end{array}$ & $\begin{array}{c}-0.154^{* *} \\
(0.075)\end{array}$ & $\begin{array}{c}-0.367^{* *} \\
(0.156)\end{array}$ & $\begin{array}{c}-0.351^{* *} \\
(0.154)\end{array}$ & $\begin{array}{c}-0.370^{* *} \\
(0.178)\end{array}$ & $\begin{array}{r}-0.331^{*} \\
(0.175)\end{array}$ \\
\hline Colony FE: & yes & yes & yes & yes & yes & yes \\
\hline Border-region FE: & no & no & yes & yes & yes & yes \\
\hline $\begin{array}{l}\text { Dist } 2 \text { border } \times \text { French: } \\
\text { Dist } 2 \text { border } \times \text { French }\end{array}$ & no & no & yes & yes & yes & yes \\
\hline$\times$ Precol. centr.: & no & no & yes & yes & yes & yes \\
\hline Dist. cutoff (dec. degr.): & - & - & 5 & 5 & 2.5 & 2.5 \\
\hline Baseline controls: & no & yes & no & yes & no & yes \\
\hline Nature controls: & no & yes & no & yes & no & yes \\
\hline Ethnic controls: & no & yes & no & yes & no & yes \\
\hline Mean DV & 1.51 & 1.52 & 0.17 & 0.19 & 0.17 & 0.19 \\
\hline Observations & 92,954 & 92,065 & 13,455 & 13,141 & 7,899 & 7,745 \\
\hline Adjusted $\mathrm{R}^{2}$ & 0.574 & 0.823 & 0.687 & 0.767 & 0.696 & 0.793 \\
\hline
\end{tabular}

Notes: OLS models. Standard errors are clustered on the province-level. Baseline controls include the local population density, ethnic groups' population density, and the distance to the coast as well as the closest navigable river. Nature controls consist of median altitude and slope, mean annual temperature, precipitation and evapotranspiration, the ratio of the two, agricultural suitability, and soils' suitability for cash crop production. Ethnic controls are the reliance on agriculture and pastoralism, as well as the intensity of agricultural activities. Additionally, all covariates are interacted with 'French rule'. Significance codes: ${ }^{*} \mathrm{p}<0.1$; ${ }^{* *} \mathrm{p}<0.05 ;{ }^{* * *} \mathrm{p}<0.01$.

I implement three robustness checks to this analysis. First, I continuously vary the distance-to-border cutoff between .1 and 5 decimal degrees. Figure A13 shows no statistically significant discontinuity in the effect of precolonial centralization on district sizes once when I restrict the sample to units very close to the border. The discontinuity becomes statistically significant with the sample of cells closer to 1.5 


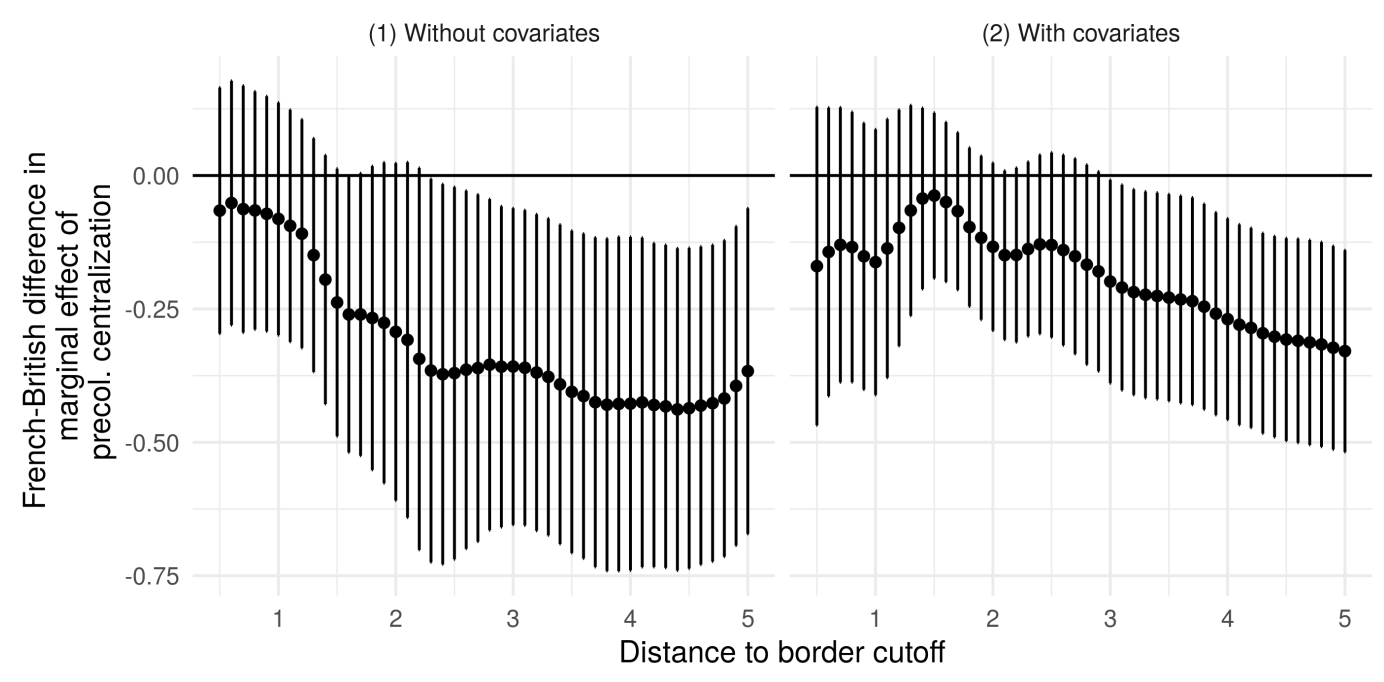

Figure A13: French-British difference in the marginal effect of precolonial centralization with varying cutoffs of the maximum distance to the closest border.

Point estimates with $95 \%$ confidence intervals represent $\beta_{1}$ from Equation 2 estimated with varying distance-to-border cutoffs.

(2) decimal degrees in the Model without (with) covariates. The second robustness check tests whether the choice of the size of grid cells affects the analysis. Figure A14 suggests the results to be robust to variation in the size of grid cells. It plots the results from RDD-estimates based on the the centroids of grid cells of a resolution of .083 (the baseline), .17, .25, and .33 decimal degrees. The estimated difference in the effect of precolonial centralization on district sizes at the French-British border hardly varies between the models.

The third robustness check addresses the caveat that parts of the two borders might have been locally adjusted to prevailing socio-demographic conditions and might therefore not be locally as-if-random. Griffiths (1986) for example points to the 1906 French-British agreement on the border between Nigeria and Dahomey which allowed small indentations of up to $8 \mathrm{~km}$ for towns and villages (see also Brownlie, 1979, 165-189). Assuming that the approximate location of the border was still as-if-randomly determined by the race of the colonial powers towards the continent's interior, we can drop all observations very close to the border, were they would be affected by endogenous local adjustments. If the estimates would be driven by such adjustments, coefficient sizes would decrease and approach zero. Table A20 presents the results from this 'donut'-RDD for which I drop all grid-cells closer to $10 \mathrm{~km}$ to the borders. This yields coefficients that are larger than the ones estimated in the baseline model. The results are thus not driven by potentially endogenous local adjustments of colonial borders. 


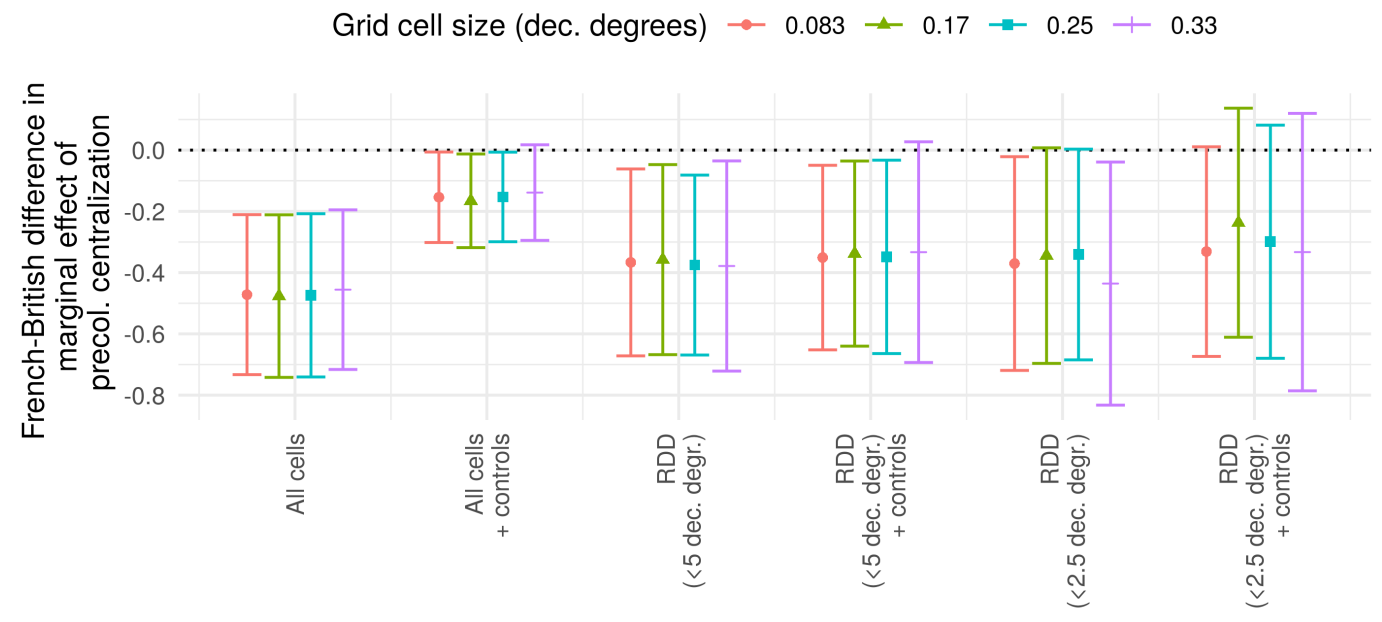

Figure A14: Re-estimating all models in Table A19 with varying sizes of centroids' grid cells.

Point estimates with $95 \%$ confidence intervals represent $\beta_{1}$ from Equation 2.

Table A20: Precolonial centralization and the size of districts: RDD at French-British borders, donut specification

\begin{tabular}{lcccc}
\hline \hline & \multicolumn{4}{c}{ Regression Discontinuity Design } \\
\cline { 2 - 5 } & $(1)$ & $(2)$ & $(3)$ & $(4)$ \\
\hline Precol. centr. $\times$ French & $-0.397^{* *}$ & $-0.353^{* *}$ & $-0.449^{* *}$ & $-0.395^{* *}$ \\
& $(0.163)$ & $(0.160)$ & $(0.196)$ & $(0.193)$ \\
& & & & \\
\hline Colony FE: & yes & yes & yes & yes \\
Border-region FE: & yes & yes & yes & yes \\
Dist2border $\times$ French: & yes & yes & yes & yes \\
Dist2border $\times$ French & & & & \\
× Precol. centr.: & yes & yes & yes & yes \\
Min. dist. (dec. degr.): & 0.1 & 0.1 & 0.1 & 0.1 \\
Dist. cutoff (dec. degr.): & 5 & 5 & 2.5 & 2.5 \\
Baseline controls: & no & yes & no & yes \\
Nature controls: & no & yes & no & yes \\
Ethnic controls: & no & yes & no & yes \\
Mean DV & 0.17 & 0.19 & 0.17 & 0.19 \\
Observations & 13,140 & 12,830 & 7,584 & 7,434 \\
Adjusted R & 0.688 & 0.770 & 0.694 & 0.795 \\
\hline \hline
\end{tabular}

Notes: OLS models. Standard errors are clustered on the province-level. Baseline controls include the local population density, ethnic groups' population density, and the distance to the coast as well as the closest navigable river. Nature controls consist of median altitude and slope, mean annual temperature, precipitation and evapotranspiration, the ratio of the two, agricultural suitability, and soils' suitability for cash crop production. Ethnic controls are the reliance on agriculture and pastoralism, as well as the intensity of agricultural activities. Additionally, all covariates are interacted with 'French rule'. Significance codes: ${ }^{*} \mathrm{p}<0.1$; ${ }^{* *} \mathrm{p}<0.05{ }^{* * *} \mathrm{p}<0.01$. 


\section{A3.4 British administrators}

Table A21: Local-level European Administrators: Nigeria and Uganda

\begin{tabular}{lcccc}
\hline \hline & \multicolumn{4}{c}{ European administrators per million } \\
& $(1)$ & $(2)$ & $(3)$ & $(4)$ \\
\hline Precol. centralization & $-2.395^{* *}$ & -0.701 & $-3.597^{* *}$ & -1.330 \\
& $(1.157)$ & $(1.760)$ & $(1.551)$ & $(1.929)$ \\
& & & & \\
\hline Colony FE: & yes & yes & yes & yes \\
Baseline controls: & yes & yes & yes & yes \\
Nature controls: & no & yes & no & yes \\
Ethnic controls: & no & no & yes & yes \\
Mean DV: & 15 & 15 & 15 & 15 \\
Observations & 34 & 34 & 34 & 34 \\
Adjusted R & 0.495 & 0.506 & 0.497 & 0.446 \\
\hline \hline
\end{tabular}

Notes: OLS models. Standard errors are clustered on the district-level. The sample consists of the colonies of Nigeria and Uganda. Baseline controls consist of the logged 1880 population density of the district and its ethnic groups, the logged distance to coast and closest navigable river, and, for per-capita outcomes, the logged district area and population. Nature controls are the median altitude and slope, mean annual temperature, precipitation and evapotranspiration, the ratio of the two, agricultural suitability, and soils' suitability for cash crop production. Ethnic controls include the reliance on agriculture and pastoralism, as well as the intensity of agricultural activities. Significance codes: ${ }^{*} \mathrm{p}<0.1 ;{ }^{* *} \mathrm{p}<0.05 ;{ }^{* * *} \mathrm{p}<0.01$.

In order to test whether precolonial centralization affects not only the size of British districts, but also directly the administrative effort exerted by the British colonial government, Table A21 presents models of the association between the centralization of precolonial polities and the number of British administrators per million inhabitants in 34 Nigerian and Ugandan provinces and districts. Although the number of observations is very small, the correlation is substantive. Without the vectors of controls added in Models 2-4, one additional level of centralization is associated with 2.4 administrators per million - a variables with a mean of only 14.8 in the sample. Adding the vector of ethnic control (Model 3) increase the size of the coefficient of precolonial centralization. However, adding the vector of 'nature' controls renders the association smaller and insignificant. While this casts doubt on the stability of the results, cautious interpretation is necessary here. First, none of the additional variables is either significant or improves the fit of the model by much. Furthermore, with 34 observations in the sample, the addition of the rather long vector of eight and later eleven controls in Model 4 likely causes multicolinearities that render the coefficients meaningless. 


\section{A4 Evidence from native administrations}

The following section presents additional analyses on the effect of precolonial centralization on the indigenous side of local governance, in particular native authorities' budgets. Subsection A4.1 presents all robustness checks highlighted in the main text. Subsection A4.3 discusses the results of an analysis of public finance data from French West Africa. And lastly, Subsection A4.4 presents analysis on the association between precolonial centralization and the status of chiefs in colonial Nigeria.

\section{A4.1 Robustness checks}

Following the robustness checks conducted in the analyses of polities' survival and district sizes, I test whether the results are driven by (1) potential omitted variables, specifically the disease environment (Malaria and Tsetse suitability), (2) the unequal weight of colonies, and (3) outliers. Furthermore, I test whether collapsing the original panel data on budgets into a cross-sectional data set biased the results. To that intent, I (4) estimate a district-weighted panel model. Furthermore, I (5) model the data in a hierarchical manner, including colony fixed effects and district random effects. As Table A22 demonstrates, none of these changes the estimated effect of precolonial centralization on native treasuries' revenues. The estimated association between revenues per capita and precolonial centralization remains stable in size and statistical significance.

Noting that the measurement of precolonial centralization might be imperfect, I also reestimate the main model using the alternative proxies for precolonial centralization in Table A23. First, I use the Murdock-mapping of Michalopoulos and Papaioannou (2013) (Models 1-2) which differs slightly from the mapping produced by Nunn and Wantchekon (2011) used in the main analysis. This does not affect the estimated effect of pre-colonial centralization. I then draw on a dummy for whether a district comprises a polity's capital in 1885, based on the data on precolonial polities collected for the first empirical part of this study. Districts with a capital in 1885 exhibit 76 percent larger budgets (Model 3), but not on a per-capita basis (Model 4). This might be indicative of differential effectiveness of indirect rule in rural and urban(izing) areas that developed around the old centers of society. However, it must be noted that a simple "capital in 1885" dummy is not precise enough to mirror variation in the level of centralization of precolonial polities and does not provide information about the spatial extent of its polity. Because of the resulting measurement error, the results might also biased towards zero. Also, in order to gauge the consistency of the budget data with that on the power of chiefs (see Subsection A4.4, Models 5 and 6 finally test whether, in Nigeria, the class of the most powerful chief in a district is indeed associated with the size of native treasuries. It 
Table A22: Per-capita revenues: Robustness checks

\begin{tabular}{lccccc}
\hline \hline & \multicolumn{5}{c}{ Revenues p.c. (log) } \\
\cline { 2 - 6 } & Desease & Col.-weight & No outlier & Wght. panel & HLM \\
& $(1)$ & $(2)$ & $(3)$ & $(4)$ & $(5)$ \\
\hline Precol. centralization & $0.24^{* * *}$ & $0.24^{* * *}$ & $0.19^{* * *}$ & $0.23^{* * *}$ & $0.20^{* *}$ \\
& $(0.09)$ & $(0.07)$ & $(0.07)$ & $(0.07)$ & $(0.08)$ \\
& & & & & \\
\hline Fixed effect: & colony & colony & colony & col.-year & col.-year \\
Baseline controls: & yes & yes & yes & yes & yes \\
Nature controls: & yes & yes & yes & yes & yes \\
Ethnic controls: & yes & yes & yes & yes & 1.2 \\
Mean DV: & 1.1 & 1.1 & 1.2 & 1,315 & 1,765 \\
Observations & 146 & 146 & 138 & 0.64 & -588.62 \\
Adjusted R & 0.62 & 0.79 & 0.64 & & $1,345.24$ \\
Log Likelihood & & & & & $1,805.22$ \\
Akaike Inf. Crit. & & & & & \\
Bayesian Inf. Crit. & & & & & \\
\hline \hline
\end{tabular}

Notes: OLS models in 1-4, hierarchical linear model in 5. The sample includes the colonies of the Gold Coast (Ghana), Nigeria, Nyasaland (Malawi), and Uganda. Standard errors are clustered on the province-level. Baseline controls are the logged 1880 population density of the district and its ethnic groups, the logged distance to coast and closest navigable river, and the logged district area and population. Nature controls include the median altitude and slope, mean annual temperature, precipitation and evapotranspiration, the ratio of the two, agricultural suitability, and soils' suitability for cash crop production. Ethnic controls are the reliance on agriculture and pastoralism, as well as the intensity of agricultural activities. Significance codes: ${ }^{*} \mathrm{p}<0.1$; ${ }^{* *} \mathrm{p}<0.05 ;{ }^{* * *} \mathrm{p}<0.01$.

emerges that treasuries were 130 (58) percent bigger in absolute (per-capita) terms in districts with a "first class" as compared to those with a "second class" chief.

Lastly, detailed information on budget lines retrieved from the official reports allows me to further explore the implications of precolonial institutions on the financial governance of native treasuries. Although standardizing budget items across many and changing formats adds uncertainty and noise to the data, ${ }^{145}$ it is of substantial interest to know whether the above reported patterns are driven by only a few or all budget lines. All respective results are reported in Tables A24 and A25. Disaggregating the revenue side shows that all revenue items are positively related to precolonial institutions, while the largest effects are visible for per capita revenues from 'fees and fines' and a category of 'other' revenues, which, inter alia, includes revenues from interests on savings. Unfortunately, the financial reporting of taxation was such that it is impossible to disentangle the amount of collected taxes from the amount of rebated taxes, which is ultimately reported in the budgets. On the expenditure side reported in Table A25, we see significant and positive effects of precolonial centralization across almost all items, in particular items relating to

\footnotetext{
${ }^{145}$ I standardize the varying items into their smallest common denominator in order to derive the most consistent data set possible.
} 
Table A23: Revenues $(2016 £)$ : Alternative specifications

\begin{tabular}{|c|c|c|c|c|c|c|}
\hline & \multicolumn{6}{|c|}{ Revenues (log): } \\
\hline & $\begin{array}{c}\text { Total } \\
(1)\end{array}$ & $\begin{array}{c}\text { Per capita } \\
(2)\end{array}$ & $\begin{array}{c}\text { Total } \\
(3)\end{array}$ & $\begin{array}{c}\text { Per capita } \\
(4)\end{array}$ & $\begin{array}{c}\text { Total } \\
(5)\end{array}$ & $\begin{array}{c}\text { Per capita } \\
(6)\end{array}$ \\
\hline Precol. centr. (M\&P) & $\begin{array}{l}0.55^{* * *} \\
(0.13)\end{array}$ & $\begin{array}{l}0.21^{* * *} \\
(0.07)\end{array}$ & & & & \\
\hline Capital 1885 & & & $\begin{array}{l}0.57^{* *} \\
(0.22)\end{array}$ & $\begin{array}{c}0.13 \\
(0.15)\end{array}$ & & \\
\hline Chief class & & & & & $\begin{array}{l}0.85^{* * *} \\
(0.15)\end{array}$ & $\begin{array}{l}0.46^{* * *} \\
(0.09)\end{array}$ \\
\hline Colony FE: & yes & yes & yes & yes & yes & yes \\
\hline Baseline controls: & yes & yes & yes & yes & yes & yes \\
\hline Nature controls: & yes & yes & yes & yes & yes & yes \\
\hline Ethnic controls: & yes & yes & yes & yes & yes & yes \\
\hline Mean DV: & 13 & 1.1 & 13 & 1.1 & 13 & 0.87 \\
\hline Observations & 144 & 144 & 146 & 146 & 86 & 86 \\
\hline Adjusted $\mathrm{R}^{2}$ & 0.58 & 0.61 & 0.52 & 0.60 & 0.50 & 0.24 \\
\hline
\end{tabular}

Notes: OLS models. Standard errors are clustered on the province-level. The sample includes the colonies of the Gold Coast (Ghana), Nigeria, Nyasaland (Malawi), and Uganda. Baseline controls consist of the logged 1880 population density of the district and its ethnic groups, the logged distance to coast and closest navigable river, and, for per-capita outcomes, the logged district area and population. Nature controls are the median altitude and slope, mean annual temperature, precipitation and evapotranspiration, the ratio of the two, agricultural suitability, and soils' suitability for cash crop production. Ethnic controls include the reliance on agriculture and pastoralism, as well as the intensity of agricultural activities. Significance codes: ${ }^{*} \mathrm{p}<0.1 ;{ }^{* *} \mathrm{p}<0.05 ;{ }^{* * *} \mathrm{p}<0.01$.

per capita spending on administration, social services such as education and health, as well as expenditure for agricultural development. The one insignificant but also positive coefficient is estimated for lines spent on 'law and order'. This might be of substantive importance, given that a reading of historical accounts suggests that areas under direct control were more prone to violent resistance against British rule (e.g. Martin, 1988). 
Table A24: Native treasury revenues per capita by type $(2016 £)$

\begin{tabular}{|c|c|c|c|c|}
\hline & \multicolumn{4}{|c|}{ Revenues/capita (log) } \\
\hline & Taxes & Fees \& fines & Transfers & Other \\
\hline & (1) & $(2)$ & $(3)$ & (4) \\
\hline Precol. centralization & $\begin{array}{c}0.168^{* *} \\
(0.081)\end{array}$ & $\begin{array}{l}0.272^{\text {*** }} \\
(0.103)\end{array}$ & $\begin{array}{c}0.285 \\
(0.607)\end{array}$ & $\begin{array}{c}0.382^{* *} \\
(0.164)\end{array}$ \\
\hline Colony FE: & yes & yes & yes & yes \\
\hline Baseline controls: & yes & yes & yes & yes \\
\hline Nature controls: & yes & yes & yes & yes \\
\hline Ethnic controls: & yes & yes & yes & yes \\
\hline Mean DV: & 0.53 & -0.77 & -5.5 & -1.4 \\
\hline Observations & 146 & 146 & 146 & 127 \\
\hline Adjusted $\mathrm{R}^{2}$ & 0.412 & 0.707 & 0.680 & 0.473 \\
\hline
\end{tabular}

Notes: OLS models. Standard errors are clustered on the province-level. The sample includes the colonies of the Gold Coast (Ghana), Nigeria, Nyasaland (Malawi), and Uganda. Baseline controls consist of the logged 1880 population density of the district and its ethnic groups, the logged distance to coast and closest navigable river, and, for per-capita outcomes, the logged district area and population. Nature controls are the median altitude and slope, mean annual temperature, precipitation and evapotranspiration, the ratio of the two, agricultural suitability, and soils' suitability for cash crop production. Ethnic controls include the reliance on agriculture and pastoralism, as well as the intensity of agricultural activities. Significance codes: ${ }^{*} \mathrm{p}<0.1 ;{ }^{* *} \mathrm{p}<0.05$; ${ }^{* * *} \mathrm{p}<0.01$.

Table A25: Native treasury expenditures per capita by type $(2016 £)$

\begin{tabular}{lcccccc}
\hline \hline & \multicolumn{7}{c}{ Expenditures/capita (log) } \\
\cline { 2 - 7 } & Admin. & Order & Educ. \& Health & Agric. & Works & Other \\
& $(1)$ & $(2)$ & $(3)$ & $(4)$ & $(5)$ & $(6)$ \\
\hline Precol. centralization & $0.27^{* *}$ & 0.13 & $0.38^{* *}$ & $0.94^{* * *}$ & $0.29^{* *}$ & $0.35^{* * *}$ \\
& $(0.10)$ & $(0.09)$ & $(0.17)$ & $(0.26)$ & $(0.11)$ & $(0.12)$ \\
& & & & & & \\
\hline Colony FE: & yes & yes & yes & yes & yes & yes \\
Baseline controls: & yes & yes & yes & yes & yes & yes \\
Nature controls: & yes & yes & yes & yes & yes & yes \\
Ethnic controls: & yes & yes & yes & yes & yes & yes \\
Mean DV: & -0.098 & -0.57 & -0.94 & -3.2 & -0.23 & -1.4 \\
Observations & 126 & 126 & 126 & 126 & 126 & 126 \\
Adjusted R & 0.51 & 0.27 & 0.53 & 0.35 & 0.41 & 0.75 \\
\hline \hline
\end{tabular}

Notes: OLS models. Standard errors are clustered on the province-level. The sample includes the colonies of the Gold Coast (Ghana), Nigeria, Nyasaland (Malawi), and Uganda. Baseline controls consist of the logged 1880 population density of the district and its ethnic groups, the logged distance to coast and closest navigable river, and, for per-capita outcomes, the logged district area and population. Nature controls are the median altitude and slope, mean annual temperature, precipitation and evapotranspiration, the ratio of the two, agricultural suitability, and soils' suitability for cash crop production. Ethnic controls include the reliance on agriculture and pastoralism, as well as the intensity of agricultural activities. Significance codes: ${ }^{*} \mathrm{p}<0.1 ;{ }^{* *} \mathrm{p}<0.05 ;{ }^{* * *} \mathrm{p}<0.01$. 


\section{A4.2 Colony-level jackknife}

In line with the main analyses on polities' survival and districts' sizes, I again check the robustness of the results to iteratively dropping each of the four colonies from the sample. In the case of the data on native administrations' budgets, this test comes with the limitation that the sample for a large part consists of observations from Nigeria $(N=86,59 \%$ of the sample), whereas the Gold Coast $(N=29)$, Nyasaland $(N=19)$, and Uganda $(N=13)$ contribute much less power to the analysis. Given the much reduced statistical power, I therefore re-estimate the baseline models of the effect of precol. centralization with and without colony fixed effects. The comparison of the resulting specifications with the full sample in the top row of Figure A15 reveals that the colony fixed effects do not have a systematic or large effect on the results.

The results are presented in the remaining rows of Figure A15. They show an unsurprising large effect of observations from Nigeria which increases as more and more covariates are added. Nigeria drives the entirety of the results with the full set of covariates. However, given that dropping Nigeria leaves us with only 61 observations in a model with 17 covariates ( 20 covariates with the fixed effects). The results of the models without the fixed effects indicate, in the two specifications without the "ethnic controls' that correlated significantly with the indicator for precol. centralization that there is an effect of more centralized districts having access to more revenues. This result relies in part on the comparison of the comparatively centralized Gold Coast and Uganda with less centralized Nyasaland.

Colony fixed effects: $\rightarrow$ no $\rightarrow$ yes

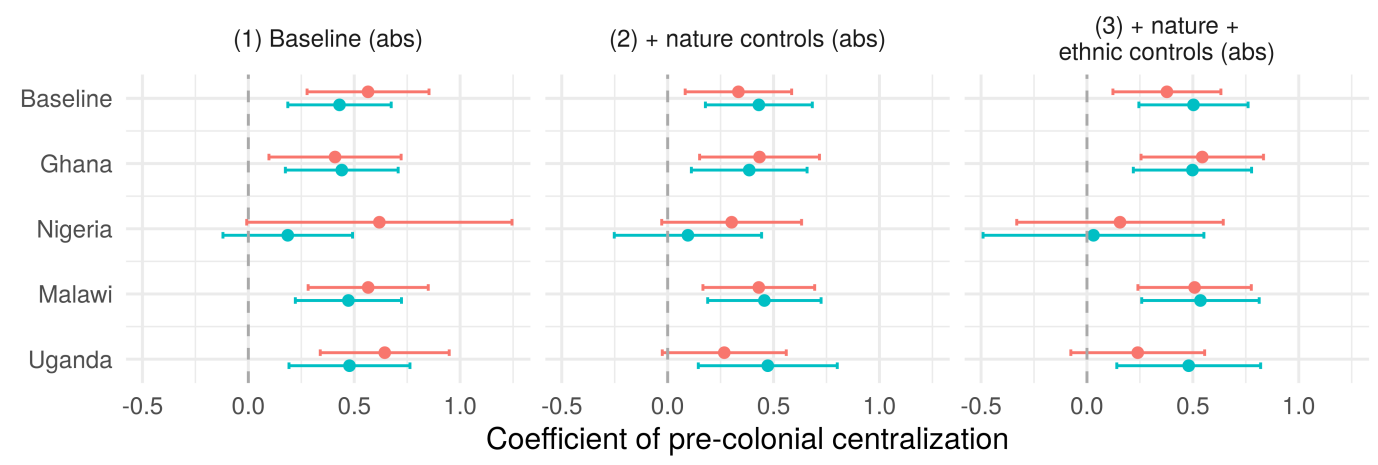

Figure A15: Colony-level jackknife: Estimated effects of precol. centralization in British colonies on the absolute amount of expenditures of native administration when iteratively dropping each colony from the sample. 


\section{A4.3 French West Africa}

To explore whether district finances in French colonies were marked by similar or opposite dynamics, I make use of Huillery's (2010) data on tax collection, public investments, and the number of teachers and doctors in 109 French West African cercles. Unfortunately, the data are not of the same format as those collected from the British colonies. They do neither contain total local revenues and expenditures, nor do they allow for a breakdown of local budgets. With that limitation in mind, I proceed in parallel to the analysis of the British budget data, reporting results of analyses of absolute outcomes in Table A26 and of per-capita outcomes in Table A27. The results show that precolonially centralization had, if at all, a negative effect on the size of district budgets in French West Africa. They are thus similar in direction but not precision to those of the analysis of districts' sizes. Centralized districts had no differential tax collection, but featured lower rates of investments and numbers of teachers and doctors employed by the French. This is similar to results previously reported by Huillery (2010). In per-capita terms, only the number of doctors is significantly lower in centralized districts than elsewhere. All other indicators yield statistically insignificant results. The negative or insignificant associations highlight once again the different pattern of local governance by direct and indirect means apparent in the British and French colonies.

Table A26: Precolonial centralization and absolute local revenues \& expenditures (logged): French West Africa

\begin{tabular}{lcccc}
\hline \hline & Taxes & Public works & Teachers & Doctors \\
& $(1)$ & $(2)$ & $(3)$ & $(4)$ \\
\hline Precol. centralization & 0.012 & -0.347 & $-0.200^{* *}$ & $-0.343^{* * *}$ \\
& $(0.180)$ & $(0.215)$ & $(0.098)$ & $(0.112)$ \\
& & & & \\
\hline Colony FE: & yes & yes & yes & yes \\
Baseline controls: & yes & yes & yes & yes \\
Nature controls: & yes & yes & yes & yes \\
Ethnic controls: & yes & yes & yes & yes \\
Mean DV: & 13 & 13 & 1.8 & 2.2 \\
Observations & 109 & 109 & 109 & 109 \\
Adjusted R & 0.682 & 0.839 & 0.521 & 0.325 \\
\hline \hline
\end{tabular}

Notes: OLS models. Standard errors are clustered on the province-level. The sample consists of all French colonies in West Africa. Baseline controls consist of the logged 1880 population density of the district and its ethnic groups, the logged distance to coast and closest navigable river, and, for per-capita outcomes, the logged district area and population. Nature controls are the median altitude and slope, mean annual temperature, precipitation and evapotranspiration, the ratio of the two, agricultural suitability, and soils' suitability for cash crop production. Ethnic controls include the reliance on agriculture and pastoralism, as well as the intensity of agricultural activities. Significance codes: ${ }^{*} \mathrm{p}<0.1 ;{ }^{* *} \mathrm{p}<0.05 ;{ }^{* * *} \mathrm{p}<0.01$. 
Table A27: Precolonial centralization and local revenues \& expenditures per-capita (logged): French West Africa

\begin{tabular}{lcccc}
\hline \hline & Taxes & Public works & Teachers & Doctors \\
& $(1)$ & $(2)$ & $(3)$ & $(4)$ \\
\hline Precol. centralization & 0.153 & -0.143 & -0.117 & $-0.274^{* *}$ \\
& $(0.186)$ & $(0.189)$ & $(0.084)$ & $(0.104)$ \\
& & & & \\
\hline Colony FE: & yes & yes & yes & yes \\
Baseline controls: & yes & yes & yes & yes \\
Nature controls: & yes & yes & yes & yes \\
Ethnic controls: & yes & yes & yes & yes \\
Mean DV: & 1.6 & 1.4 & -9.6 & -9.2 \\
Observations & 109 & 109 & 109 & 109 \\
Adjusted R & 0.701 & 0.901 & 0.776 & 0.651 \\
\hline \hline
\end{tabular}

Notes: OLS models. Standard errors are clustered on the province-level. The sample consists of all French colonies in West Africa. Baseline controls consist of the logged 1880 population density of the district and its ethnic groups, the logged distance to coast and closest navigable river, and, for per-capita outcomes, the logged district area and population. Nature controls are the median altitude and slope, mean annual temperature, precipitation and evapotranspiration, the ratio of the two, agricultural suitability, and soils' suitability for cash crop production. Ethnic controls include the reliance on agriculture and pastoralism, as well as the intensity of agricultural activities. Significance codes: ${ }^{*} \mathrm{p}<0.1 ;{ }^{* *} \mathrm{p}<0.05 ;{ }^{* * *} \mathrm{p}<0.01$.

\section{A4.4 Chiefs' class in colonial Nigeria}

Table A28 summarizes the results from an analysis of the association between the level of precolonial centralization and the highest class of chiefs in Nigerian districts. The results point to a significant correspondence of the two: The most powerful chief in a district has a class (ranging from 1 to three, the highest) that increase between .28 and .48 points with each level of hierarchy featured in the districts' precolonial institutions (0-3). This is further evidence that the British devolved more power to local authorities that could build on pre-existing institutions. 
Table A28: Highest class of chief in district: Nigeria (1924/1929)

\begin{tabular}{lccc}
\hline \hline & \multicolumn{3}{c}{ Highest class of chief $(1-3)$} \\
& $(1)$ & $(2)$ & $(3)$ \\
\hline Precol. centralization & $0.477^{* * *}$ & $0.288^{*}$ & $0.276^{*}$ \\
& $(0.088)$ & $(0.146)$ & $(0.139)$ \\
& & & yes \\
\hline Colony FE: & yes & yes & yes \\
Baseline controls: & yes & yes & yes \\
Nature controls: & no & yes & yes \\
Ethnic controls: & no & no & 1.6 \\
Mean DV: & 1.6 & 1.6 & 86 \\
Observations & 86 & 86 & 0.470 \\
Adjusted R & 0.427 & 0.454 & \\
\hline \hline
\end{tabular}

Notes: OLS models. Standard errors are clustered on the district-level. The sample consists of the colony of Nigeria. Baseline controls consist of the logged 1880 population density of the district and its ethnic groups, the logged distance to coast and closest navigable river, and, for per-capita outcomes, the logged district area and population. Nature controls are the median altitude and slope, mean annual temperature, precipitation and evapotranspiration, the ratio of the two, agricultural suitability, and soils' suitability for cash crop production. Ethnic controls include the reliance on agriculture and pastoralism, as well as the intensity of agricultural activities. Significance codes: ${ }^{*} \mathrm{p}<0.1 ;{ }^{* *} \mathrm{p}<0.05$; ${ }^{* * *} \mathrm{p}<0.01$. 